\title{
Andrezza Camarinha Napolitano Barcelos
}

Análise comparativa da expressão de citoqueratinas, involucrina, filagrina e e-caderina em verrugas planas e em lesões do tipo verruga plana na Epidermodisplasia Verruciforme

Dissertação apresentada à Faculdade de Medicina da Universidade de São Paulo para obtenção do título de Mestre em Ciências

Área de concentração: Dermatologia

Orientadora: Profa. Dra. Mírian Nacagami Sotto

São Paulo

2008 


\section{Dados Internacionais de Catalogação na Publicação (CIP)}

Preparada pela Biblioteca da

Faculdade de Medicina da Universidade de São Paulo

(S) reprodução autorizada pelo autor

Barcelos, Andrezza Camarinha Napolitano

Análise comparativa da expressão de citoqueratinas, involucrina, filagrina e ecaderina em verrugas planas e em lesões do tipo verruga plana na

Epidermodisplasia Verruciforme / Andrezza Camarinha Napolitano Barcelos. -São Paulo, 2008.

Dissertação(mestrado)--Faculdade de Medicina da Universidade de São Paulo. Departamento de Dermatologia.

Area de concentração: Dermatologia.

Orientadora: Mirian Nacagami Sotto.

Descritores: 1.Epidermodisplasia vernuciformis 2.Verrugas 3.Queratinas 4.Caderinas

USP/FM/SBD-161/08 


\section{DEDICATÓRIA}


a Jesus Cristo e a Nossa Senhora por sempre guiarem todos os meus passos e à MINHA FAMílIA por sempre me apoiar na caminhada.

Querido CADU, meu companheiro, obrigada pela paciência, pelo incentivo e pelo amor: esse filho também é seu. 
AgRADECIMENTOS 
À Prof. Dra. Mírian Nacagami Sotto, minha orientadora, por todo seu apoio, sua ajuda nos momentos difíceis, sua paciência e compreensão. Trabalhar sob sua orientação foi uma honra e seus ensinamentos irão me acompanhar por toda a vida.

Ao Prof. Dr. Evandro A. Rivitti pela oportunidade.

Às Técnicas do Laboratório de Dermatopatologia da Divisão da Clínica Dermatológica, Maria Cristina Galhardo, Jacqueline Maria Cruz Aragão e Ivete Isabel Torres, pelo auxílio com os procedimentos técnicos histológicos.

Ao Técnico Cleiton Alves, pelo seu inestimável auxílio na realização da técnica de imunohistoquímica.

Ao Prof. Dr. Heitor Franco de Andrade Júnior por sua ajuda com as análises estatísticas.

A Sra. Eli Maria de Freitas Ferreira pelo auxílio em tantos momentos.

Às Bibliotecárias Kátia Clemente e Ângela da Silva Bezerra pela ajuda com parte das referências. 
À Prof. Dra. Celina W. Maruta, por sua compreensão e ajuda em momentos importantes.

Aos meus amigos companheiros de pós-graduação, pelo estímulo, amizade e por toda a troca de informações.

A todos os colegas da Divisão da Clínica Dermatológica pelo apoio e incentivo.

Aos pacientes envolvidos no estudo, que diretamente contribuíram para a sua realização e que são, em última instância, a motivação maior de qualquer pesquisa científica. 
Esta Dissertação está de acordo com as seguintes normas, em vigor no momento desta publicação:

Referências: adaptado de International Committee of Medical Journals Editors (Vancouver)

Universidade de São Paulo. Faculdade de Medicina. Serviço de Biblioteca e Documentação. Guia de apresentação de dissertações, teses e monografias. Elaborado por Anneliese Carneiro da Cunha, Maria Julia de A. L. Freddi, Maria F. Crestana, Marinalva de Souza Aragão, Suely Campos Cardoso, Valéria Vilhena. $2^{\mathrm{a}}$ ed. São Paulo: Serviço de Biblioteca e Documentação; 2005.

Abreviaturas dos títulos dos periódicos de acordo com List of Journals Indexed in Index Medicus. 
SUMÁRIO 


\section{S U MÁ RIO}

Lista de abreviaturas

Lista de figuras

Lista de tabelas

Resumo

Summary

INTRODUÇÃO …….................................... 2

$1.1 \quad$ Epidermodisplasia verruciforme................................. 2

$1.2 \quad$ Citoqueratinas ..................................................... 5

$1.3 \quad$ Involucrina ......................................................... 6

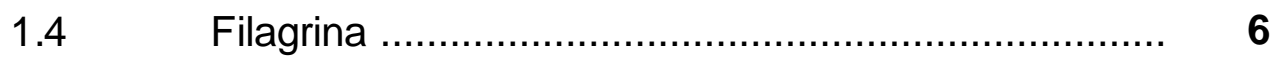

$1.5 \quad$ E-caderinas ..................................................... 7

$1.6 \quad$ Expressão de citoqueratinas em verrugas virais ....... 7

2 OBJETIVOS …………………….................. 9

$3 \quad$ REVISÃO DE LITERATURA …............................. 11

3.1 Epidermodisplasia verruciforme …......................... 11 
3.1.1 Histórico …........................................................ 11

3.1.2 Epidemiologia ...................................................... 12

3.1.3 Apresentação clínica ............................................. 14

3.1.4 Achados histopatológicos e ultraestruturais ............. 19

3.1.5 Etiologia e patogênese ............................................. 24

3.1.5.1 Agentes infecciosos …………………............... 24

3.1.5.1.1 Estrutura dos HPV .............................................. 24

3.1.5.1.2 Classificação dos HPV ......................................... 26

3.1.5.1.3 HPV relacionados à verruga plana na população em

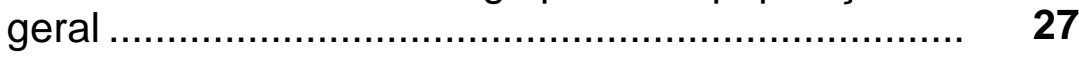

3.1.5.1.4 HPV relacionados à EV (EV-HPV) .......................... 28

3.1.5.1.5 Patogênese da infecção pelo HPV ......................... 31

3.1.5.2 Fatores ambientais ............................................ 34

3.1.5.3 Fatores genéticos ……………………............... 37

3.1.5.4 Aspectos imunológicos ......................................... 41

3.1.5.5 Oncogênese nos doentes com EV ........................... 45

3.1.6 Tratamento ................................................... 46

3.2 Citoqueratinas ................................................. 48 
3.3 Involucrina ....................................................... 53

3.4 Filagrina …............................................... 55

3.5 E-caderina ..................................................... 57

3.6 Citoqueratinas, involucrina, filagrina e e-caderina e HPV ............................................................... 58

$4 \quad$ MÉTODO e CASUÍSTICA …............................... 61

4.1 Casuística .................................................... 61

4.2 Análise histopatológica ………………................. 63

4.3 Técnica imuno-histoquímica para a demonstração da expressão de citoqueratinas, involucrina, filagrina e e-caderina ............................................. 63

$4.4 \quad$ Análise qualitativa ............................................... 67

$4.5 \quad$ Análise estatística ........................................... 68

$5 \quad$ RESULTADOS …....................................... 70

5.1 Caracterização da casuística …………................. 70

5.2 Análise histopatológica ........................................... 71

5.3 Expressão das citoqueratinas, involucrina, filagrina e e-caderina nos espécimes controle ...................... 73

5.3.1 Expressão de citoqueratinas nas verrugas planas e na EV

74

5.3.1.1 Citoqueratinas 1 , 10 e 14 ................................... 74 


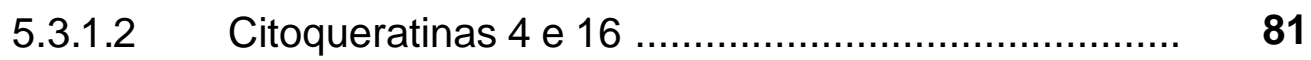

5.3.2 Expressão de involucrina, filagrina e e-caderina nas verrugas planas e na EV ........................................ 84

5.3.2.1 Involucrina ..................................................... 84

5.3.2.2 Filagrina .............................................................. 87

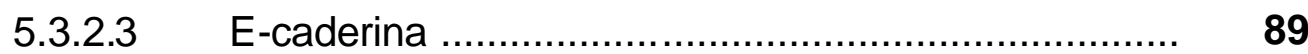

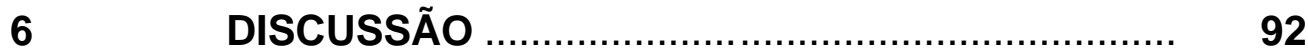

6.1 Citoqueratinas ............................................ 95

6.1.1 A expressão das citoqueratinas 1,10 e 14 está alterada, especialmente nas lesões de epidermodisplasia verruciforme.

6.1.2 As citoqueratinas 4 e 16 são expressas nas verrugas planas e na epidermodisplasia verruciforme

6.1.3. As alterações das citoqueratinas encontradas nas verrugas planas e epidermodisplasia verruciforme não se correlacionam com a exposição

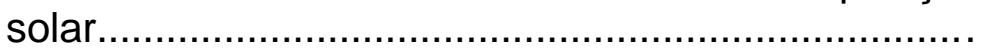

6.2 Involucrina

6.2.1 A expressão de involucrina ocorreu mais próxima à camada basal nas verrugas planas e na epidermodisplasia verruciforme

6.3 Filagrina e e-caderina 
6.3.1 A expressão de filagrina e e-caderina não é marcadamente alterada nas verrugas planas e na epidermodisplasia verruciforme............................... 107

6.4 Considerações finais............................................. 111

$7 \quad$ CONCLUSÕES .................................................. 114

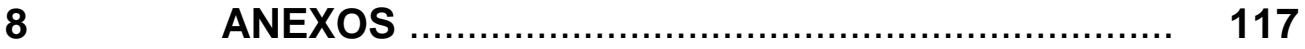

9

REFERÊNCIAS …....................................... 125 


\section{LISTAS}




\section{Abreviaturas}

AP-1 Fator de transcrição AP-1
CAPPesq Comissão de Ética para Análise de Projetos de Pesquisa
CBC Carcinoma espinocelular
CEC Carcinoma basocelular
DNA Ácido desoxirribonucléico
DNCB Dinitroclorobenzeno
E Early (gene ou proteína early do HPV)
EV Epidermodisplasia verruciforme
EV-HPV Vírus do papiloma humano associado à EV
HAR Herança autossômica dominante

HC-FMUSP Hospital das Clínicas da Faculdade de Medicina da Universidade de São Paulo

HE Hematoxilina e eosina

HPV Vírus do papiloma humano

IL-1 Interleucina-1

K Citoqueratina

kDa Kilodalton

L Late (gene ou proteína late do HPV)

LCR Long control region

ME Microscopia eletrônica

MHC Complexo maior de histocompatibilidade

MMII Membros inferiores

MMSS Membros superiores 


\author{
mRNA Ácido ribonucléico \\ MTF-1 Fator de transcrição regulador de metais \\ NK Células natural killer \\ PCR Reação em cadeia da polimerase \\ PM Peso molecular \\ QA Queratose actínica \\ SPR/SPRR Pequenas proteínas ricas em prolina (small \\ proline rich proteins) \\ TMC Transmembrane channel-like gene family \\ TGF $\beta \quad$ Fator de crescimento tumoral $\beta$ \\ TNF $\alpha \quad$ Fator de necrose tumoral $\alpha$ \\ UV Ultravioleta \\ VLP Virus like particle \\ VP Verruga plana \\ ZnT-1 Transportador de zinco
}




\section{FIGURAS}

Figura 1 Epidermodisplasia verruciforme, apresentação clínica. Lesões semelhantes à pitiríase versicolor no dorso

Figura 2 Epidermodisplasia verruciforme, histopatologia de lesão do tipo verruga plana. Queratinócitos suprabasais volumosos, de citoplasma cinza-azulado, grânulos de querato-hialina irregulares e pleomorfismo nuclear moderado (hematoxilina-eosina, aumento original 200x) .......................

Figura 3 Verruga plana comum, histopatologia apresentando hiperqueratose em cesta, acantose leve a moderada e queratinócitos com halos claros perinucleares - "olhos de pássaro" (hematoxilina-eosina, aumento original 200x) ........

Figura 4 Epidermodisplasia verruciforme. Microscopia eletrônica de transmissão. Partículas virais com arranjo cristalóide no núcleo de queratinócito epidérmico (aumento original 45.000x). Queratinócito com dilatação das cisternas do retículo endoplasmático ao redor de núcleo irregular (inset aumento original $9.500 \times$ )

Figura 5 Esquema de organização do genoma do HPV 16

Figura 6 Ciclo de vida do HPV no epitélio escamoso estratificado. O HPV infecta as células basais do epitélio. Após a perda da cápside o genoma viral é transportado ao núcleo onde os genes "E" são transcritos. Na camada espinhosa há um estado de equilíbrio da replicação viral e expressão dos genes " $E$ ". As partículas virais são produzidas nas camadas superficiais do epitélio (em diferenciação terminal) (HPV: vírus do papiloma humano; E: gene early)

Figura 7 Esquema com estratificação topográfica da epiderme considerada no presente estudo

Figura 8 Verruga plana, histopatologia. Epiderme com hiperqueratose, acantose, leve papilomatose e queratinócitos coilocitóticos nas camadas granulosa e espinhosa superior. (Hematoxilina e eosina; x200) 
Figura 9 Epidermodisplasia verruciforme, histopatologia de lesão do tipo verruga plana. Epiderme com acantose e hiperqueratose moderadas; células acantóticas com aumento de volume, halo perinuclear e citoplasma cinzaazulado; com grânulos de querato-hialina irregulares. (Hematoxilina e eosina; $x 200$ ).

Figura 10 Expressão de citoqueratina 1 (K1) em toda camada espinhosa, (A) epiderme normal -controle, (x200); (B) verruga plana (VP) (x100), (C) lesão do tipo verruga plana na epidermodisplasia verruciforme (EV) (x200). (técnica da estreptoavidina-biotinaperoxidase)

Figura 11 Expressão de citoqueratina 10 (K10) em toda a camada espinhosa na (A) epiderme normal - controle (x100) e (B) verruga plana (VP) (x100). (C) Expressão de K10 apenas na camada espinhosa superior na epidermodisplasia verruciforme (EV) (x100) (técnica de estreptoavidinabiotina-peroxidase

Figura 12 Expressão de citoqueratina 14 (K14) na (A) epiderme normal - controle; (B) verruga plana; (C) epidermodisplasia verruciforme (técnica de estreptoavidina-biotinaperoxidase)

Figura 13 Epidermodisplasia verruciforme (EV). (A) Expressão de citoqueratina 1 (K1) apenas na camada espinhosa superior. (B) Expressão negativa de citoqueratina 10 (K10). (C) Expressão de citoqueratina 14 (K14) em toda a epiderme (técnica de estreptoavidina -biotina-peroxidase)

Figura 14 Expressão difusa de citoqueratina $4(\mathrm{~K} 4)$ na (A) verruga plana e na (B) epidermodisplasia verruciforme (técnica de estreptoavidina-biotina-peroxidase)

Figura 15 Expressão de citoqueratina 16 (K16) na (A) verruga plana e na (B) epidermodisplasia verruciforme (técnica de estreptoavidina-biotina-peroxidase) 
Figura 16 Expressão de involucrina na epiderme (A) normal- controle; (B) verruga plana e (C) epidermodisplasia verruciforme (técnica de estreptoavidina -biotina-peroxidase)

Figura 17 Expressão de filagrina na (A) epiderme normal- controle, (B) verruga plana e (C) epidermodisplasia verruciforme (técnica de estreptoavidina -biotina-peroxidase)

Figura 18 Expressão de e-caderina na (A) epiderme normatcontrole, (B) verruga plana e (C) epidermodisplasia verruciforme (técnica de estreptoavidina-biotina-peroxidase) 


\section{T ABELAS}

Tabela 1 Principais características das formas clínicas da epidermodisplasia verruciforme .........................................

Tabela 2 Dados de literatura quanto ao tipo e localização de 126 cânceres cutâneos relatados em pacientes com epidermodisplasia verruciforme (período de 1965-2001)

Tabela 3 Freqüência de detecção de vírus do papiloma humano pela reação em cadeia da polimerase em lesões cutâneas e pele normal

Tabela 4 Expressão e distribuição dos pares de citoqueratinas no tegumento humano.

Tabela 5 Anticorpos primários, clones, fabricante e diluição utilizados no estudo

Tabela 6 Localização topográfica das lesões com relação à exposição solar....

Tabela 7 Expressão de citoqueratinas 1, 10, 14, involucrina, filagrina e e-caderina na epiderme de grupo controle de pele normal $\mathbf{7 4}$

Tabela 8 Padrão de expressão da citoqueratina 1 nas verrugas planas e nas lesões de epidermodisplasia verruciforme ...... 76

Tabela 9 Padrão de expressão da citoqueratina 10 nas verrugas planas e nas lesões de epidermodisplasia verruciforme

Tabela 10 Padrão de expressão da citoqueratina 14 nas verrugas planas e nas lesões de epidermodisplasia verruciforme .....

Tabela 11 Padrão de expressão da citoqueratina 4 nas verrugas planas e nas lesões de epidermodisplasia verruciforme ...... 81

Tabela 12 Padrão de expressão da citoqueratina 16 nas verrugas planas e nas lesões de epidermodisplasia verruciforme

Tabela 13 Padrão de expressão da involucrina nas verrugas planas e nas lesões de epidermodisplasia verruciforme

Tabela 14 Expressão epidérmica de e-caderina nas verrugas planas e nas lesões de epidermodisplasia verruciforme 
REsumo 
Barcelos ACN. Análise comparativa da expressão de citoqueratinas, involucrina, filagrina e ecaderina em verrugas planas e em lesões do tipo verruga plana na Epidermodisplasia Verruciforme [dissertação]. São Paulo: Faculdade de Medicina, Universidade de São Paulo; 2008. 147p.

Introdução: A epidermodosplasia verruciforme (EV) é uma genodermatose rara, caracterizada por maior susceptibilidade à infecção cutânea pelos vírus do papiloma humano (HPV), causando, entre outras lesões, verrugas planas (VP) disseminadas. Há freqüente transformação maligna das lesões na idade adulta, sendo a EV considerada um modelo de oncogênese viral cutânea. Citoqueratinas (K) são componentes do citoesqueleto de células epiteliais. Os queratinócitos epidérmicos expressam K5 e K14 (camada basal) e K1 e K10 (camadas suprabasais). A epiderme hiperproliferativa expressa K16, e a epiderme fetal e epitélios não queratinizados expressam K4. A involucrina (componente do envelope corneificado) e a filagrina (presente nos grânulos de querato-hialina) são marcadores da diferenciação terminal da epiderme. E-caderinas são glicoproteínas transmembrânicas mediadoras da adesão intercelular, importantes como supressoras de metástases. Não há dados de literatura sobre o perfil das $\mathrm{K}$, involucrina, filagrina e e-caderina nas lesões de VP na EV. Objetivos: realizar uma análise comparativa da expressão epidérmica das $K 1,10,14,4,16$; involucrina, filagrina e ecaderina em VP de doentes com EV e em VP de indivíduos da população geral, visando contribuir para uma melhor compreensão da patogênese da EV. Métodos: Cortes histológicos de tecidos fixados em formalina e embebidos em parafina de 15 casos de EV e 14 
casos de VP foram marcados com anticorpos monoclonais contra $\mathrm{K} 1,10$, 14, 4, 16, involucrina e ecaderina, por técnica de imunoperoxidase. Dez fragmentos de pele normal (produtos de mamo e abdominoplastias) foram utilizados como controles. Resultados: Ocorreu expressão de K1/10 nas camadas mais superficiais da epiderme em ambos os grupos (mais superficial na EV). Em 33,33\% dos casos de EV houve ausência de expressão de K10. Esta foi substituída pela expressão de K14 nas camadas suprabasais. Ambos os grupos exibiram expressão basal e suprabasal de K14 (até as camadas mais superficiais na EV) e positividade para K4 e K16. Involucrina foi detectada nas camadas suprabasais da epiderme em todos os casos, sendo expressa nas camadas mais inferiores quando comparada aos controles. A expressão de filagrina não se mostrou alterada. Houve diminuição da expressão de e-caderina nos focos de coilocitose em ambos os grupos de lesão, sendo mais superficial na EV. Conclusão: A infecção pelo HPV altera o processo de queratinização da epiderme nas verrugas planas e nas verrugas planas associadas à EV. Ocorre diminuição da expressão suprabasal de K1 e K10, que são aparentemente substituídas pela expressão suprabasal de K14 e expressão aberrante de K4 e K16. Ocorre formação precoce do envelope celular com expressão de involucrina nas camadas mais inferiores da epiderme, tanto nas lesões de verruga plana como na verruga plana da EV. A expressão de filagrina não se altera em ambos os grupos de lesão viral. A expressão de ecaderina é de padrão habitual intercelular epidérmico, exceto nos focos de coilocitose, onde se apresentou diminuída. As alterações observadas são mais acentuadas nas 
lesões de verruga plana associadas à EV e poderiam se correlacionar com o potencial oncogênico cutâneo da doença.

Descritores: 1.Epidermodisplasia verriciformis 2.Verrugas 3.Queratinas 4.Caderinas. 
SUMMARY 
Barcelos ACN. Comparative analysis of the expression of cytokeratins, involucrin, filaggrin and ecadherin in plane warts and Epidermodysplasia Verruciformis plane wart-type lesions [dissertation]. São Paulo: "Faculdade de Medicina, Universidade de São Paulo"; 2008. 147p.

Introduction: Epidermodysplasia verruciformis $(E V)$ is a rare genodermatosis with increased susceptibility to human papillomavirus (HPV) infection, causing, among other lesions, disseminated plane warts (PW). There is frequent malignant transformation of the lesions during adulthood, thus EV is considered a model of viral cutaneous oncogenesis. Cytokeratins (K) are components of the cytoskeleton of epithelial cells. Keratinocytes express K5/14 (basal layer) and K1/ K10 (suprabasal layers). Hyperproliferative epidermis expresses $\mathrm{K} 16$, and fetal epidermis and non-keratinizing epithelia express K4. Involucrin (component of the cornified envelope) and filaggrin (present in the keratohyalin granules) are markers of epidermal terminal differentiation. E-cadherins are transmembranic glycoproteins that mediate intercellular adhesion and are suppressors of metastasis. There are no data addressing cytokeratins involucrin, filaggrin and e-cadherin expression profile in PW lesions in EV. Objectives: To perform a comparative analysis of the epidermal expression of $K 1,10,14,4,16$; involucrin, filaggrin and ecadherin in PW of individuals with EV and PW in individuals in general population, aiming a better understanding of EV pathogenesis. Methods: Formalin-fixed/paraffin-embedded specimens from 15 cases of EV and 14 cases of PW were subjected to immunoperoxidase technique with 
monoclonal antibodies against $\mathrm{K} 1,10,14,4,16$, involucrin, filaggrin and ecadherin. Ten normal skin fragments (from mammo and abdominoplasty) were used as controls. Pesults: There was $\mathrm{K} 1 / 10$ expression in the most superficial epidermal layers in both groups, mainly in EV. K10 expression was negative in $33.33 \%$ of $\mathrm{EV}$ cases, being replaced by $\mathrm{K} 14$, which was expressed also in suprabasal layers. K14 was positive in basal and suprabasal layers in both groups. In EV its expression persisted up to the superficial epidermal layers. K4 and K16 were expressed in epidermal parabasal and spinous layers in both groups. Involucrin was detected in suprabasal layers in all cases and it was expressed in more inferior layers than in controls. Filaggrin expression was not altered. Both lesions displayed diminished expression of e-cadherin in superficial koilocytic foci, mainly in EV lesions. Conclusion: The process of keratinization is noticeably altered in plane warts and EV lesions. There is a retarded or absent expression of $\mathrm{K} 1 / \mathrm{K} 10$ which is replaced by $\mathrm{K} 14$ expression. The viral lesions exhibit an aberrant K16 and K4 expression. There is an alteration of the keratinocytes' envelope with precocious involucrin expression, although filaggrin expression is not altered. E-cadherin expression is diminished in the superficial koilocytic foci, mainly in EV lesions. These alterations are more conspicuous in EV lesions and may be related to the oncogenic potential of the disease.

Descriptors: 1.Epidermodysplasia verruciformis 2.Warts 3.Keratins 4.Cadherins. 
INTRODUÇÃO 


\section{INTRODUÇÃO}

\subsection{Epidermodisplasia verruciforme}

A epidermodisplasia verruciforme é uma genodermatose rara, caracterizada por uma susceptibilidade anormal à infecção por um grupo específico de vírus do papiloma humano (HPV), denominados EV-HPV (Jablonska et al., 1979; Lutzner et al., 1984).

A herança é usualmente autossômica recessiva, embora casos de herança autossômica dominante e recessiva ligada ao $\mathrm{X}$ sejam relatados (Rajagopalan et al., 1972; Lutzner, 1978; Androphy et al., 1985; Seghal et al., 2002; Mc Kusick, 1998 apud Aochi et al., 2007). Sua etiopatogenia não está totalmente esclarecida, e envolve predisposição genética, infecção pelo HPV, distúrbios imunológicos e exposição à radiação ultravioleta, entre outros fatores (Jablonska e Majewski, 1994; de Oliveira et al., 2003a; Orth, 2006).

A doença manifesta-se na infância, usualmente pela presença de múltiplas lesões de verrugas planas, máculas semelhantes às da pitiríase 
versicolor e queratoses seborréicas. (Lutzner, 1978; Jablonska et al, 1979; Jablonska e Majewski, 1994; Majewski e Jablonska, 1997a; Oliveira, 1999, Oliveira et al, 2002; de Oliveira et al, 2003a; Roncalli de Oliveira et al, 2003). As membranas mucosas usualmente não são afetadas (Orth, 2006).

A transformação maligna das lesões ocorre em cerca de 30 a $50 \%$ dos doentes, geralmente após a terceira década de vida, e seu aparecimento depende do potencial oncogênico do vírus envolvido (Jablonska et al., 1972; Orth et al.,1979; Majewski e Jablonska, 1992; Majewski e Jablonska, 1997 a; 1997 b; Oliveira et al., 2006). As neoplasias ocorrem principalmente nas áreas de maior exposição ao sol. (Lutzner, 1978; Oliveira, 1999; Oliveira et al., 2002, Lowy e Androphy, 1999).

A EV apresenta interesse especial de estudo principalmente pela alta incidência de tumores malignos, sendo considerada como modelo de oncogênese viral cutânea (Majewski e Jablonska, 1995; 2001; 2002).

O defeito genético específico que determina o desenvolvimento de neoplasias cutâneas na EV ainda não foi identificado, mas dois loci de susceptibilidade para EV foram demonstrados nos cromossomos 17 e 2 (Ramoz et al., 1999; 2000).

Verrugas planas (VP) são lesões elevadas de superfície achatada, de aproximadamente dois a quatro milímetros, com mínima descamação, geralmente localizadas na face, mãos e pernas, sendo em geral numerosas (dezenas a centenas). Acometem indivíduos imunocompetentes e imunossuprimidos (Sampaio e Rivitti, 1998; Lowy e Androphy, 1999; Kyriakis 
et al., 2007). São mais freqüentes nas crianças e adolescentes, por isso também são denominadas verrugas planas juvenis. (Sampaio e Rivitti, 1998). As VP na população em geral são freqüentemente associadas aos HPV 3, 10, 28 e 49 (Lowy e Androphy 1999).

Kyriakis et al. (2006) em um estudo com 50237 pacientes ambulatoriais atendidos consecutivamente evidenciaram uma prevalência geral de VP de 0,54\%, com maior pico de prevalência entre 6 e 10 anos de idade. A proporção entre verrugas comuns e VP foi de 9,6: 1.

O quadro histológico das verrugas planas comuns e o das verrugas planas da EV causadas por HPV não relacionados à EV (por exemplo, HPV 3 e 10) são semelhantes (Orth et al., 1979; Majewski et al., 1997a). Ocorre acantose leve a moderada, com presença de células com halos perinucleares, e hiperqueratose em cesta leve a moderada (Orth et al., 1979; Jablonska e Majewski, 1994; Majewski et al., 1997). Nas verrugas planas causadas pelos EV-HPV, além das alterações anteriores, observam-se nas camadas espinhosa e granulosa células volumosas, às vezes em agrupamentos, com citoplasma abundante, pálido e acinzentado, com halo claro perinuclear, grânulos de querato-hialina de várias formas e tamanhos, e núcleos grandes. Essas células são características do efeito citopático viral dos EV-HPV. Pode haver também queratinócitos displásicos (Majewski et al., 1997; Majewski e Jablonska, 1997a; Nuovo e Ishag, 2000). A derme usualmente não exibe alterações significativas (Weedon, 2002). 


\subsection{Citoqueratinas}

Os queratinócitos mantém sua estrutura tridimensional graças à presença de um citoesqueleto formado por filamentos de citoqueratinas (K). As citoqueratinas são proteínas presentes em todas as células epiteliais, e sua distribuição é específica para cada subtipo de epitélio, permitindo que sejam utilizadas como marcadores de diferenciação epitelial (Smack et al., 1994).

$\mathrm{Na}$ epiderme os queratinócitos basais expressam K5 e K14, e as camadas suprabasais expressam K1 e 10 (Moll et al., 1982; Smack et al., 1994; Almeida Jr., 2004).

A K4 é característica dos epitélios estratificados não queratinizados como o esofágico (Moll et al., 1982; Leube et al., 1988; Cribier e Grosshans, 1993; Smack et al., 1994; Almeida Jr, 2004,). Não é encontrada na epiderme adulta normal, sendo expressa, porém na epiderme fetal (Van Muijen et al., 1987; Smack et al., 1994).

Nos estados hiperproliferativos da epiderme ocorre substituição da expressão de K1/10 por K 6/16. Isso é observado, por exemplo, na psoríase (Leigh et al., 1995), na epiderme em regeneração (Kallioinem et al., 1995; Kurokawa et al., 2006) e em dermatoses infecto-parasitárias associadas à hiperplasia epidérmica (Nogueira-Castañon et al., 2004). 


\subsection{Involucrina}

A involucrina é componente do envelope corneificado das células da camada córnea, sendo um dos primeiros marcadores de diferenciação terminal do epitélio. Acredita-se que a involucrina sirva como uma base precoce da estrutura do envelope celular, à qual outras proteínas se ligariam (Ishida-Yamamoto et al., 1997; Candi et al., 2005).

\section{$1.4 \quad$ Filagrina}

A filagrina está presente nos grânulos de querato-hialina da camada granulosa e no envelope corneificado, e serve como matriz protéica para promover a agregação e ligações dissulfídicas dos filamentos de queratina, além de participar na regulação da osmolaridade e flexibilidade da pele (Smack et al., 1994; Steinert e Marekov, 1995; Candi et al., 2005). 


\section{$1.5 \quad$ E-caderinas}

As E-caderinas são glicoproteínas transmembrânicas que participam da adesão intercelular e agem como importantes supressores da capacidade de invasão e metástases dos tumores epiteliais (Okegawa et al., 2002). Também atuam em várias outras funções celulares como moléculas sinalizadoras, na regulação do citoesqueleto e na polaridade celular (Wheelock e Jensen, 1992; Tunggal et al., 2005).

\subsection{Expressão de citoqueratinas em verrugas virais}

Nas lesões de verruga plana da população em geral, foi verificado através de métodos bioquímicos, que ocorre grande quantidade de $\mathrm{K} 1$ e pequena de $\mathrm{K} 2,4,5,6,10,11,14,15,16$ e 17 (Moll et al., 1984).

Entretanto, não há dados de literatura sobre o perfil das citoqueratinas, involucrina, filagrina e e-caderina nas lesões de verruga plana da EV. 
ObJetivos 


\section{OBJETIVOS}

O objetivo deste trabalho é determinar o padrão de expressão epidérmica das citoqueratinas 1, 10,14, 4, 16; involucrina; filagrina e ecaderina em lesões de verrugas planas de doentes com EV e compará-lo com o de verrugas planas de indivíduos da população em geral, sem EV ou outras doenças e/ou uso de drogas causadoras de imunossupressão.

Pretende-se com esse estudo contribuir para uma melhor compreensão da patogênese da EV. 
REVISÃo DA LITERATURA 


\section{REVISÃO DA LITERATURA}

\subsection{Epidermodisplasia verruciforme}

\subsubsection{Histórico}

A epidermodisplasia verruciforme (EV) é uma genodermatose rara, descrita inicialmente por Lewandosky e Lutz em 1922 apud Lutzner (1978) como sendo uma doença com anomalias cutâneas congênitas com verrugas generalizadas e tumores de pele.

O papel do vírus do papiloma humano (HPV) na EV foi aventado somente na década de 60 quando, através de microscopia eletrônica, observoutse nas lesões verrucosas da EV a presença de vírus intranucleares considerados idênticos ou fortemente relacionados aos vírus da verruga (Ruiter e van Mullem, 1966; Jablosnka et al., 1968).

A participação do HPV na gênese das lesões da EV também foi confirmada pela reprodução das lesões de verruga plana, através de 
experimentos de auto e hetero-inoculação com esfregaços de pele de doentes com EV (Jablonska et al., 1966; 1972).

Suspeitou-se do potencial oncogênico desses vírus devido à freqüente degeneração maligna das lesões cutâneas na EV (Ruiter e Van Mullem, 1970). A associação da EV com neoplasias malignas cutâneas fez com que a EV se tornasse o primeiro indicador de câncer genético associado ao vírus do papiloma humano (HPV), e um modelo para o estudo do papel dos vírus e de fatores do hospedeiro na oncogênese induzida pelo HPV (Jablonska et al., 1972; Majewski e Jablonska, 1995; 1997a).

\subsubsection{Epidemiologia}

A EV apresenta distribuição universal, independente de sexo ou raça (Lutzner, 1978; Kawashima, 1992; Oliveira et al., 2002). Sua incidência precisa é difícil de determinar devido aos relatos esporádicos de casos (Sehgal et al., 2002).

Cerca de $50 \%$ dos casos são hereditários, geralmente com herança autossômica recessiva (Lutzner, 1978; Rajagopalan et al., 1972). Casos de herança ligada ao X (Androphy et al., 1985) e herança autossômica dominante (Kanerva et al., 1985; Mc Kusik, 1998 apud Aochi et al., 2007; Sehgal et al., 2002) têm sido descritos, indicando grande heterogeneidade 
genética na EV. Consangüinidade é relatada em 10 a $85 \%$ dos casos (Lutzner, 1978; Lutzner et al., 1984; Oliveira, 1999; de Oliveira et al., 2003a).

A incidência de neoplasias cutâneas malignas em doentes com EV é maior do que a da população em geral, ocorrendo em 20 a $50 \%$ dos casos (Lutzner, 1978, Orth et al., 1979, Kawashima 1992; Oliveira et al., 2002). Os tumores ocorrem em torno da terceira e quarta décadas de vida (Lutzner, 1978; Orth et al., 1979; Majewski e Jablonska, 1997a,b; Oliveira et al., 2002).

As lesões malignas localizam-se principalmente nas áreas de maior exposição solar, indicando que a radiação ultravioleta (UV) agiria como um co-fator na malignização das lesões (Kawashima, 1992; Oliveira et al., 2002), embora a observação de lesões malignas e pré-malignas na região temporal, em outras áreas cobertas pelos cabelos e região escrotal indique a participação de outros fatores na oncogênese da EV (Majewski e Jablonska, 1997a). Africanos de pele negra com EV têm baixa incidência de lesões malignas, a despeito de apresentarem infecção por HPV oncogênicos como os tipos 5, 8 e 17, indicando o papel protetor da melanina. (Jacyk e Villiers, 1993; Jacyk et al., 1993; Caputo et al., 1995).

Em alguns casos a presença de lesões desde o nascimento indica possível transmissão vertical do HPV (Lutzner, 1978). Também favorável a essa possibilidade é a descrição de gestante com EV que apresentou os mesmos tipos de HPV nas lesões cutâneas, no esfregaço cervical e no líquido amniótico obtido antes da ruptura das membranas coriônicas (Favre et al., 1998a). 


\subsubsection{Apresentação clínica}

As lesões iniciam-se usualmente na infância (Lowy e Androphy, 1999; Kanda et al., 1989; Guimarães et al., 1997; Majewski e Jablonska, 1997a; Oliveira et al., 2002; Gül et al., 2007), embora haja relato de casos com aparecimento mais tardio, em torno dos 20 anos (Kanda et al., 1989; Jacyk e Villiers, 1993).

As lesões cutâneas associadas à EV são polimórficas. Apresentam-se como lesões de verrugas planas (normalmente mais planas e mais abundantes que na população em geral), máculas e placas eritematosas, acastanhadas ou acrômicas semelhantes à pitiríase versicolor (Figura 1) e pápulas acastanhadas semelhantes a queratoses seborréicas (Lutzner, 1978; Jablonska et al., 1979; Jablonska e Majewiski, 1994; Majewski e Jablonska, 1995; 1997a; Oliveira, 1999; Kanda et al., 1999; Jacyk et al., 1993; Tomasini et al., 1993; Oliveira et al., 2002; Roncalli de Oliveira, 2003; Gül et al., 2007). 


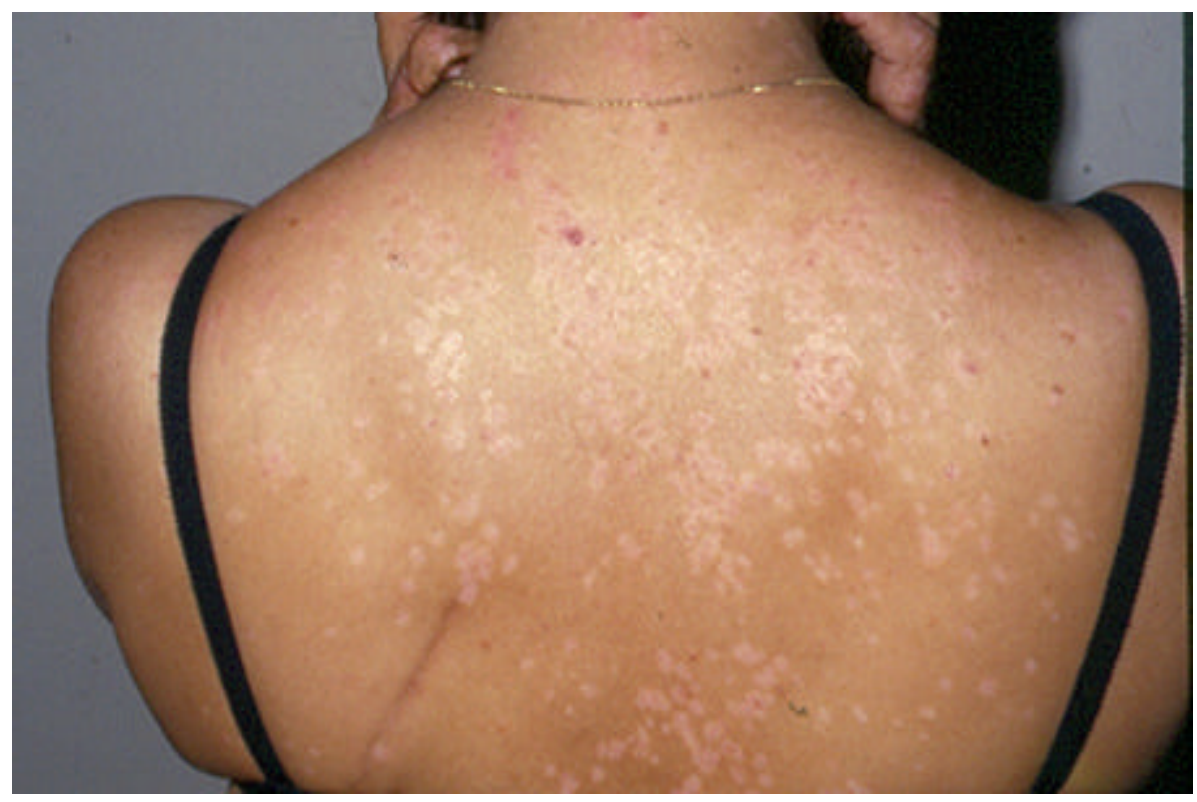

Figura 1 - Epidermodisplasia verruciforme, apresentação clínica. Lesões semelhantes à pitiríase versicolor no dorso.

FONTE: Acervo do Departamento de Dermatologia da FMUSP.

A EV é classificada em duas formas clínicas, benigna e maligna, ou tipo 1 e tipo 2, relacionadas ao tipo de HPV envolvido, características das lesões e desenvolvimento de tumores cutâneos, embora os relatos mais recentes da literatura nem sempre apresentem essa distinção, e formas mistas (com algumas características do tipo 1 e outras do tipo 2) também ocorram. (Jablonska e Majewski, 1994; Majewiski e Jablonska, 1995; Orth et al., 1979; Hultgren et al., 2007). A regressão das lesões é raramente descrita (Jablonska et al., 1992). Na Tabela 1 encontram-se as principais características das formas clínicas da EV. 
Tabela 1 - Principais características das formas clínicas da epidermodisplasia verruciforme.

\begin{tabular}{|c|c|c|}
\hline & Tipo 1 & Tipo 2 \\
\hline Idade de aparecimento & Infância & Infância \\
\hline Tipos de HPV* & 3,10 & EV-HPV $(5,8,14$ e outros $)$ \\
\hline Aspectos clínicos & Verrugas planas & $\begin{array}{l}\text { Lesões polimórficas: lesões do } \\
\text { tipo de verrugas planas, } \\
\text { pitiríase versicolor símiles, } \\
\text { queratoses seborréicas símiles }\end{array}$ \\
\hline Localização das lesões & Tronco e membros & Disseminadas \\
\hline Transformação maligna & Não & $\begin{array}{l}30-50 \% \text { dos casos, nas áreas } \\
\text { expostas ao sol e a partir dos } \\
30 \text { anos de idade }\end{array}$ \\
\hline História familiar & Ocasional & $\begin{array}{l}\text { Freqüente, predomínio de } \\
\mathrm{HAR}^{\star \star}\end{array}$ \\
\hline Alterações histopatológicas & $\begin{array}{l}\text { Verruga plana com } \\
\text { hiperqueratose, acantose } \\
\text { e vacuolização das } \\
\text { células da camada } \\
\text { granulosa }\end{array}$ & $\begin{array}{l}\text { Lesões semelhantes às } \\
\text { verrugas planas, e lesões com } \\
\text { queratinócitos grandes com } \\
\text { citoplasma cinza-azulado e } \\
\text { grânulos irregulares de } \\
\text { queratohialina }\end{array}$ \\
\hline
\end{tabular}

*HPV - vírus do papiloma humano;

** HAR - herança autossômica recessiva.

FONTE: Adaptado de Hultgren et al., 2007.

Os tumores malignos mais freqüentemente encontrados são 0 carcinoma in situ (Doença de Bowen), o carcinoma espinocelular e o carcinoma basocelular (Lutzner, 1978; Orth et al., 1979; Jablonska e Majewski, 1994; Majewski et al., 1997; Oliveira et al., 2002, Motegi et al., 2003). Essas neoplasias são localmente invasivas (Majewski e Jablonska, 1995) e têm baixo potencial metastático, exceto quando expostas a outros 
co-carcinógenos, principalmente radioterapia local (Lutzner et al., 1984; Jablonska e Majewski 1994; Majewski e Jablonska, 1997b; Cortés-Franco et al., 1997; Gül et al., 2007).

As neoplasias ocorrem em cerca de 30 a $50 \%$ dos doentes. Predominam nas áreas fotoexpostas e seu aparecimento depende principalmente do potencial oncogênico do tipo de HPV envolvido (Lutzner, 1978; Orth et al., 1979; Ostrow et al., 1982; Lutzner et al., 1984; Pfister e Ter Schegget, 1997; Kawashima, 1992; Oliveira et al., 2002; Lowy e Androphy, 1999). Os principais HPV encontrados nos carcinomas da EV são os tipos 5 e 8 (Jablosnka et al., 1979; Orth et al., 1979; Lutzner et al., 1984; Majewski e Jablonska, 1997a). No Brasil ocorre alta prevalência do HPV 14d nos carcinomas da EV, com positividade em $67 \%$ dos casos estudados (de Oliveira et al., 2004c, Oliveira et al., 2006). Os tumores desses doentes apresentaram um curso mais agressivo, com ocorrência de metástases à distância, sendo questionado se essa maior agressividade se correlacionaria com o tipo do HPV ou com a alta exposição à radiação UV em nosso país. A ocorrência de HPV 14d também foi descrita em doente negro na Colômbia (Sanclemente et al., 2006) mas com evolução mais benigna do que a dos casos observados no Brasil.

A Tabela 2 demonstra os dados da literatura quanto ao tipo e localização de neoplasias cutâneas numa série de doentes com epidermodisplasia verruciforme. 
Tabela 2 - Dados de literatura quanto ao tipo e localização de 126 cânceres cutâneos relatados em pacientes com epidermodisplasia verruciforme (período de 1965-2001).

\begin{tabular}{lc}
\hline \multicolumn{1}{c}{ Tipo de câncer } & Número de tumores \\
\hline \hline Carcinoma espinocelular & 91 \\
Doença de Bowen & 25 \\
Carcinoma basocelular & 8 \\
Carcinoma écrino & Localização \\
\hline Couro cabeludo & 2 \\
Face & 2 \\
Braço & 41 \\
Antebraço & 2 \\
Mão & 6 \\
Tronco & 3 \\
Vulva & 11 \\
Perna & 3 \\
Desconhecido & 4 \\
\hline \hline
\end{tabular}

FONTE: Adaptado de Motegi et al., 2003.

Retardo mental é descrito em 10 a 23\% dos casos (Lutzner, 1978; de Oliveira et al., 2003a; Gül et al., 2006). 
Embora envolvimento mucoso não seja descrito (Guimarães et al., 1997; Majewski e Jablosnka, 2004; Orth, 2006), o DNA de EV-HPV foi encontrado em esfregaço cervical uterino de paciente com EV (Favre et al., 1998a). O couro cabeludo também não é usualmente afetado (Guimarães et al., 1997), embora haja relato de envolvimento do mesmo (Seghal et al., 2002).

Óbitos relacionados à doença são raros. Quando ocorrem são relacionados à invasão de estruturas locais ou às metástases das neoplasias (Lutzner, 1978; Oliveira et al., 2002; de Oliveira et al., 2003a).

\subsubsection{Achados histopatológicos e ultraestruturais}

Nas lesões causadas pelo EV-HPV (independente do aspecto clínico) a alteração mais característica é o aumento do tamanho das células a partir das camadas suprabasais, que se arranjam em ninhos nas camadas espinhosa e granulosa. Os queratinócitos exibem coloração pálida cinzaazulada na coloração pela hematoxilina e eosina (HE), com citoplasma finamente granular, e os grânulos de querato-hialina são proeminentes e com formatos e tamanhos variados (Figura 2) (Jablonska e Majewski, 1994; Majewski et al., 1997; Majewski e Jablonska 1997a; Nuovo e Ishag, 2000). As lesões podem apresentar alterações displásicas (Rajagopalan et al., 1972; Nuovo e Ishag, 2000). Esse efeito citopático é característico para 
todos os EV-HPV, independentemente do genótipo (Jablonska e Majewski, 1994), sendo observado nas lesões de verruga plana, nas semelhantes à pitiríase versicolor e nas queratoses seborréicas (Jacyk et al., 1993, Tomasini et al., 1993, Roncalli Oliveira et al., 2003). A derme não apresenta alterações expressivas, com somente leve infiltrado inflamatório perivascular (Rajagopalan et al., 1972; Weedon, 2002).

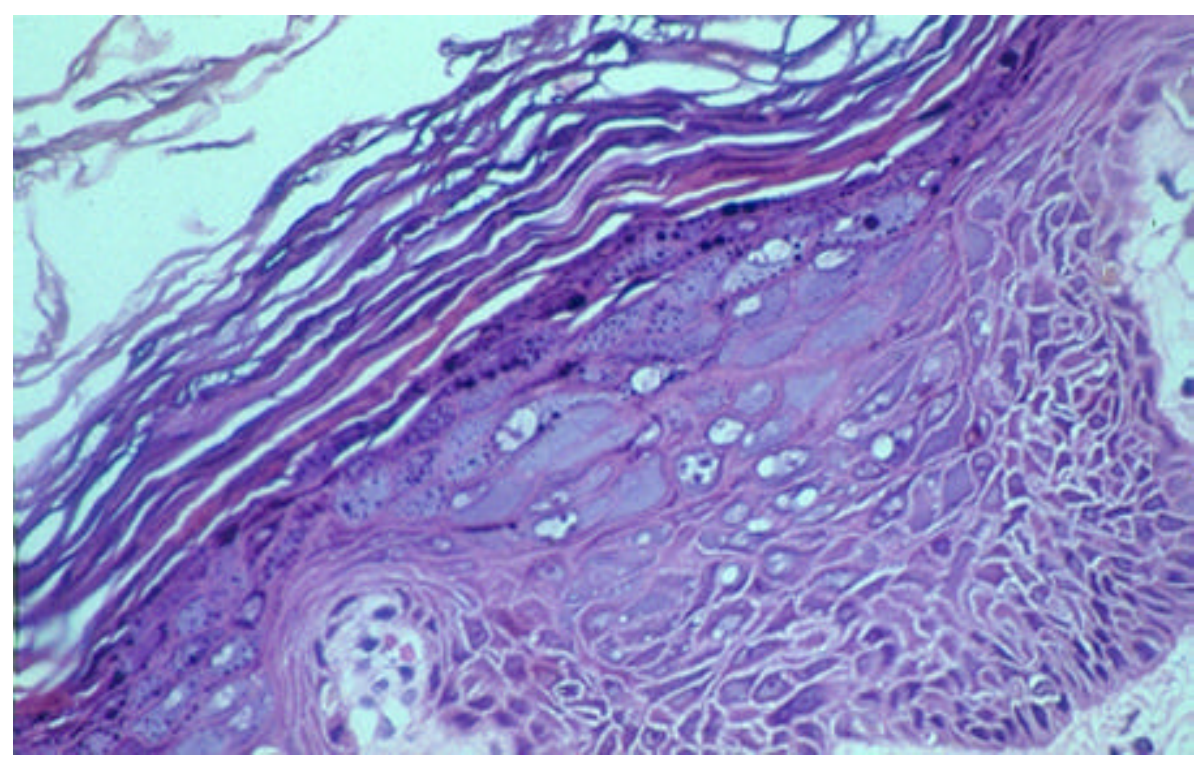

Figura 2 - Epidermodisplasia verruciforme, histopatologia de lesão do tipo verruga plana. Queratinócitos suprabasais volumosos, de citoplasma cinza-azulado, grânulos de querato-hialina irregulares e pleomorfismo nuclear moderado (hematoxilina-eosina, aumento original $200 x$ ).

As lesões induzidas pelo HPV-3 são semelhantes às verrugas planas na população em geral, com hiperqueratose em cesta leve a moderada, e acantose leve a moderada, sem ou com discreta papilomatose. Os queratinócitos exibem halos claros perinucleares, com núcleos pequenos e picnóticos (Rajagopalan et al., 1972; Orth et al., 1979; Jablonska e Majewski, 
1994; Majewski et al., 1997; Kawashima, 1992; Lowy e Androphy, 1999), com aspecto característico das células em "olhos de pássaro" (Figura 3) (Jablonska e Majewski, 1994).

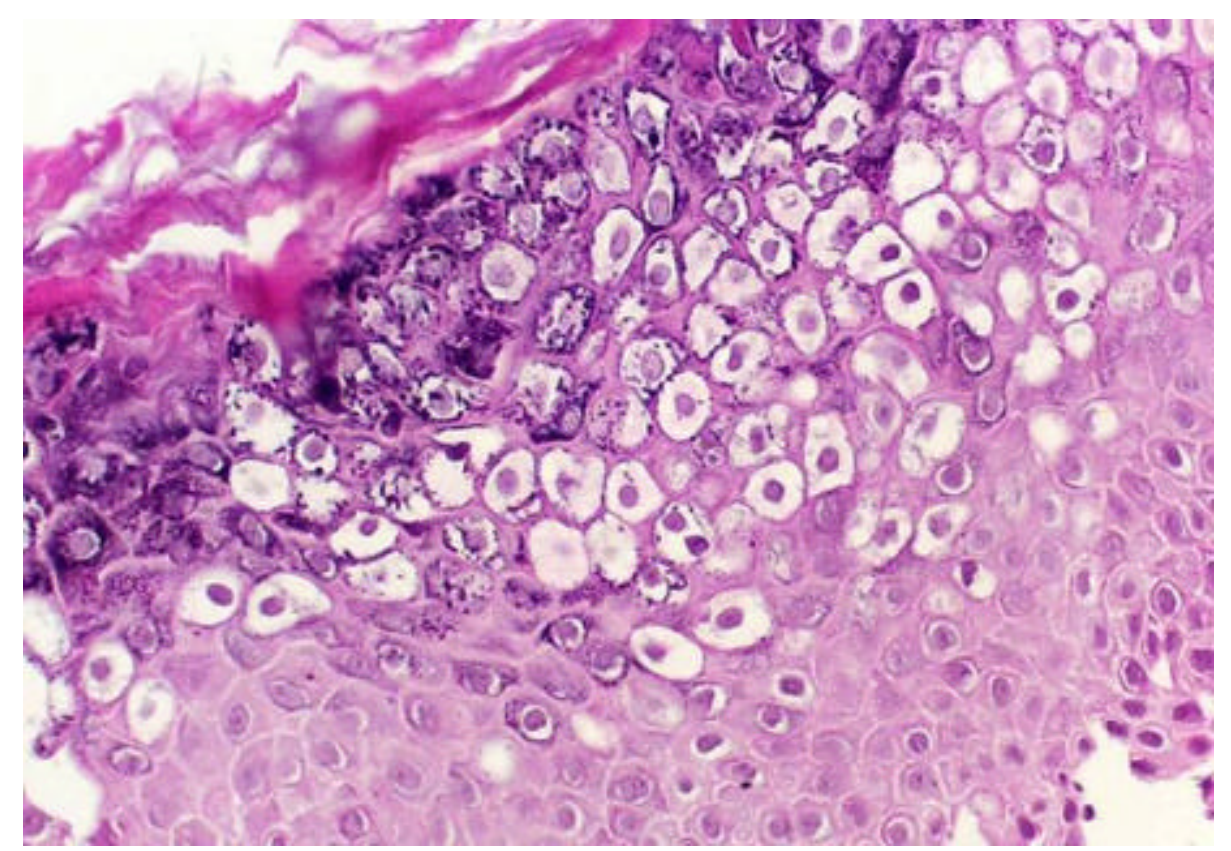

Figura 3 - Verruga plana comum, hstopatologia apresentando hiperqueratose em cesta, acantose leve a moderada e queratinócitos com halos claros perinucleares - "olhos de pássaro" (hematoxilina-eosina, aumento original $200 \times$ ).

Ko et al. (2006) demonstraram o efeito citopático viral característico da EV em cinco lesões benignas de pele não relacionadas à EV (nevo intradérmico, queratose seborréica pigmentada, lesão papulosa no antebraço, acantoma acantolítico e lesão perianal). Em três dessas lesões foi demonstrada a presença de EV-HPV pela técnica da reação em cadeia da polimerase (PCR). Alterações características de EV e EV-HPV podem ser achados incidentais na ausência de EV clínica. Quando essas alterações 
são o principal achado histopatológico propõe-se a designação de EV acantoma.

A alteração característica nos tumores da EV é a atipia bowenoide com células disqueratóticas "monstruosas", sendo a Doença de Bowen e o carcinoma espinocelular os tumores mais freqüentemente encontrados (Jablonska e Majewski, 1994; Majewski e Jablonska, 1997a). As alterações citopáticas virais são detectadas apenas nas lesões pré-malignas Nas lesões malignas o efeito citopático viral tende a desaparecer (Jablonska e Majewski, 1994).

$\mathrm{Na}$ microscopia eletrônica de lesões causadas pelos EV-HPV (Figura 4) observa-se núcleos claros preenchidos por partículas virais cristalinas, cromatina marginada e nucléolos proeminentes. No citoplasma há escassez de organelas com exceção de ribossomos. Os grânulos de querato-hialina aumentados não estão associados aos tonofilamentos (Ruiter e Van Mullen 1966; Jablonska et al., 1968; 1972; Rajagopalan et al., 1972; Jablonska e Majewski, 1994; Kanerva et al., 1985). As alterações citoplasmáticas provavelmente decorrem de degeneração secundária à disfunção nuclear (Rajagopalan et al., 1972). 


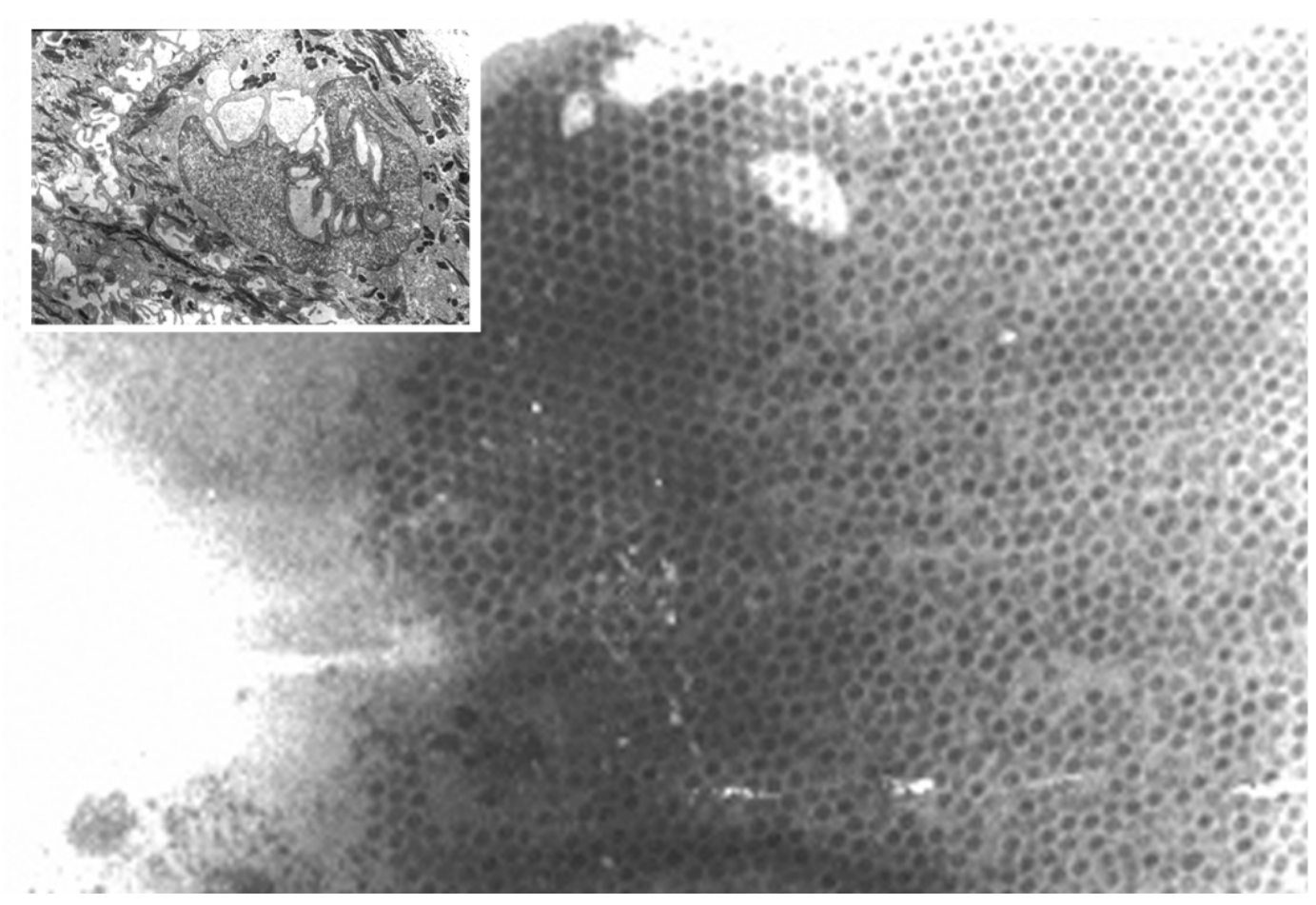

Figura 4- Epidermodisplasia verruciforme. Microscopia eletrônica de transmissão. Partículas virais com arranjo cristalóide no núcleo de queratinócito epidérmico (aumento original 45.000×). Queratinócito com dilatação das cisternas do retículo endoplasmático ao redor de núcleo irregular (inset - aumento original 9.500×).

FONTE: Acervo do Departamento de Dermatologia da FMUSP.

Conforme há progressão para malignidade ocorre diminuição no número de células contendo partículas virais, bem como diminuição da quantidade destas partículas no núcleo e perda do arranjo cristalóide (Ruiter e van Mullem, 1970; Jablonska et al., 1972; Lutzner, 1978).

Nas lesões causadas pelo HPV-3 o núcleo é bem preservado e preenchido de partículas virais em arranjo cristalino, mas sem cromatina marginada. Há uma zona vacuolada perinuclear, e as organelas 
citoplasmáticas são deslocadas para a periferia da célula (Jablonska e Majewski, 1994).

\subsubsection{Etiologia e Patogênese}

A EV é uma doença multifatorial, com participação de fatores genéticos, infecciosos, ambientais e alterações imunológicas (Orth, 1979; Majewski e Jablonska, 1992; Majewski e Jablonska, 1997a)

\subsubsection{Agentes infecciosos}

\subsection{Estrutura dos HPV}

Os agentes infecciosos relacionados à EV são os vírus do papiloma humano (HPV), que infectam epitélios escamosos estratificados e causam uma variedade de lesões de pele (Androphy, 1994). A maioria dos HPV são ubíquos e globalmente distribuídos (Antonsson et al., 2003; de Villiers et al., 2004).

Os HPV compreendem mais de 100 tipos virais de Villiers et al., 2004). São formados por duas fitas complementares de ácido desoxirribonucléico (DNA), com aproximadamente 800 nucleotídeos cada, e 
seu genoma permanece como um círculo fechado (plasmídeo ou epissomo) no núcleo das células infectadas. Apresentam um envoltório protéico externo (cápside icosaédrica), mas sem envoltório periférico lipoprotéico (Androphy, 1994; Favre et al., 1997; Pfister e Ter Schegget,1997; Harwood et al., 1999).

O genoma viral pode ser dividido em partes denominadas com "L" (late), "E" (early) e "LCR" (long control region) (Figura 5). Os genes L1 e L2 codificam as proteínas da cápside viral e as regiões "E" compreendem os genes envolvidos na regulação da replicação viral (E1 e E2) ou na proliferação e imortalização celular (E6 e E7). Além disso, a proteína E2 serve como um fator de transcrição viral, regulando a expressão dos oncogenes E6 e E7. O gene E4 codifica proteínas que se ligam às queratinas epiteliais facilitando a produção de vírions por interromper a diferenciação celular normal. Entretanto, o gene E4 não apresenta funções de replicação ou transcrição viral (Androphy, 1994; Majewski e Jablonska, 1997a).

A porção LCR contém elementos que se ligam a vários fatores de transcrição envolvidos na regulação da replicação do DNA e na expressão gênica viral (Majewski e Jablonska, 1997a).

A proteína da cápside L1 contém epítopos indutores de anticorpos neutralizantes, enquanto os epítopos de L2 são responsáveis por reatividade grupo-específica de anti-soros (Majewski e Jablonska, 1997a). 


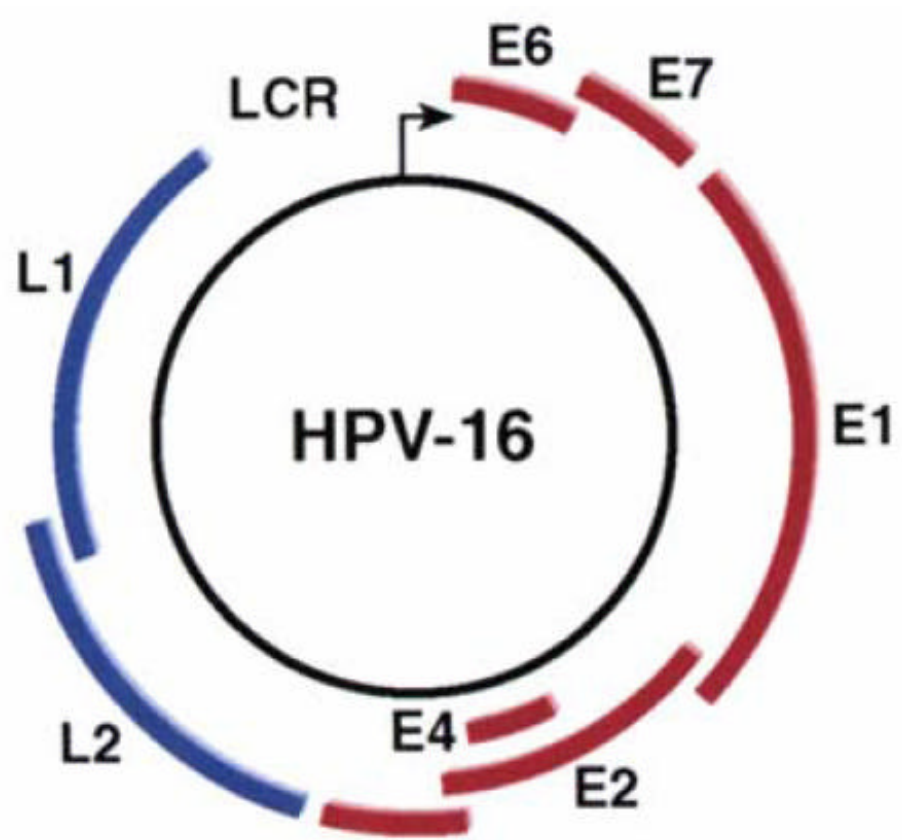

E5

Figura 5 - Esquema de organização do genoma do HPV 16. FONTE: Alani e Münger, 1998.

\subsection{Classificação dos HPV}

Atualmente os HPV são classificados em uma família taxonômica própria, a Papillomaviridae. Grupos filogenéticos de ordem maior como, por exemplo, os HPV genitais (alfa papillomavírus), são agrupados em 16 gêneros. Grupos de ordem menor dentro dos gêneros são considerados espécies. As espécies são constituídas por tipos, subtipos e variantes (de Villiers et al., 2004). 
Os HPV apresentam ampla heterogeneidade genética, demonstrada pelo estudo de sua seqüência nucleotídica (Favre et al., 1997). As variações nas seqüências nucleotídicas virais são utilizadas na caracterização de novos tipos e subtipos virais. Um novo tipo é definido quando apresentar menos de $90 \%$ de homologia na seqüência nucleotídica de seu gene L1 (região mais conservadora do genoma viral) em relação ao HPV conhecido mais intimamente relacionado. Diferenças entre 2 e $10 \%$ definem um subtipo e menores que $2 \%$ uma variante (de Villiers et al., 2004).

Os EV-HPV pertencem ao gênero Beta-papillomavirus, os HPV cutâneos não relacionados à epidermodisplasia verruciforme ao gênero Gama-papillomavírus e os genitais ao Alfa-papillomavírus (de Villiers et al., 2004). Entretanto, essa classificação não é estrita, pois HPV mucosos podem ser encontrados em lesões cutâneas e EV-HPV podem ser encontrados em indivíduos sem EV (Antonsson et al., 2003; Boxman et al., $1997 ; 1999)$.

\subsection{HPV relacionados à verruga plana na população em geral}

As verrugas planas (VP) na população em geral são freqüentemente associadas aos HPV 3, 10, 28 e 49 (Lowy e Androphy, 1999). Os HPV 3, 10 e 28 pertencem ao gênero Alfa-papillomavírus, que causam lesões cutâneas e apresentam baixo potencial de malignização. O HPV 49 pertence ao 
gênero Beta-papilomavírus, e também causa lesões cutâneas benignas (de Villiers et al., 2004).

Esses HPV também infectam e causam lesões em doentes com EV (Jablonska e Majewski, 1994; Majewski e Jablonska, 1997a).

\subsection{HPVs relacionados à EV (EV-HPV)}

Atualmente mais de 20 tipos de EV-HPV foram identificados (Majewski e Jablonska, 2001).

Os doentes de EV podem ser infectados também pelos HPV 3 e 10, causadores de VP na população em geral, e que não são classificados como EV-HPV (Jablonska e Majewski, 1994; Majewski e Jablonska, 1995; 1997a; 2001).

Os portadores de EV são usualmente infectados por diversos tipos de EV-HPV nas lesões benignas, mas os tumores cutâneos e as lesões précancerígenas (queratoses actínicas e lesões displásicas) são predominantemente associados aos HPV 5 e 8, e menos comumente aos HPV 14, 17, 20 e 47 (Orth et al., 1979; Majewski e Jablonska, 1997a; 1998; Ostrow, et al., 1982; Lutzner et al., 1984). A transformação maligna das lesões está associada ao tipo de HPV envolvido e não aos fatores imunológicos (Orth et al., 1978; Orth et al., 1979; Jablonska et al., 1979; Ostrow et al., 1982). 
No passado, acreditava-se que os EV-HPV infectavam somente doentes com EV ou indivíduos imunossuprimidos. Entretanto, com o uso de técnicas mais sensíveis de detecção, como a reação em cadeia da polimerase $(\mathrm{PCR})$, esses vírus têm sido encontrados em várias situações. Detectou-se EV-HPV na pele normal de indivíduos imunocompetentes (Astori et al., 1998; Antosson et al., 2003), nos folículos pilosos de transplantados renais e de indivíduos saudáveis (Boxman et al., 1997), nas lesões de psoríase (de Jong-Tieben et al., 1995; Harwood et al., 2004; Weissenborn et al., 1999; Favre et al., 1998b; Astori et al., 1998), e nas queratoses seborréicas fora das áreas genitais (Li et al., 2004).

Os EV-HPV também são encontrados nos tumores cutâneos nãomelanoma de indivíduos imunossuprimidos (principalmente transplantados renais), e na população em geral. Entretanto, o papel causal do HPV nos carcinomas de indivíduos imunocompetentes não é plenamente confirmado (Majewski e Jablonska, 2002; 2006; Sterling, 2005; Gewirtzman et al., 2008; Shamanin et al., 1996). Acredita-se que os EV-HPV estariam envolvidos nos estágios iniciais da oncogênese, ou atuariam como co-fatores na oncogênese conjuntamente com a radiação UV (Pfister et al., 2003; Gewirtzman et al., 2008)

Pfister et al. (2003) encontraram alta prevalência de DNA de EV-HPV nas queratoses actínicas de indivíduos imunocompetentes, e menor detecção do vírus em carcinomas. 
Forslund et al. (2004) evidenciaram alta prevalência de HPV-DNA no topo de tumores cutâneos, mas não em biopsias dos mesmos tumores onde as camadas mais superficiais da epiderme foram retiradas com adesivo. Embasados nestas observações questionaram se a presença do HPV não seria apenas uma contaminação tecidual.

Karagas et al. (2006), em estudo caso-controle, demonstraram anticorpos contra HPV mais freqüentemente em indivíduos com carcinomas espinocelulares do que nos controles, entretanto sem diferença na prevalência entre carcinomas basocelulares e controles. Observaram também maior associação do HPV5 com os carcinomas, e maior soropositividade em indivíduos com neoplasias em áreas fotoexpostas.

Stark et al. (1998) também encontraram soropositividade para HPV8 em $7,6 \%$ de indivíduos normais, $21,1 \%$ de transplantados renais e $45,6 \%$ de indivíduos imunocompetentes com tumores cutâneos não- melanoma.

Favre et al. (2000) observaram que anticorpos contra o HPV 5 são gerados em processos epidérmicos reparativos (queimaduras de segundo grau). Além disso, demonstraram DNA de HPV5 em 57,9\% dos pacientes com doenças bolhosas autoimunes.

A Tabela 3 apresenta dados de literatura quanto à detecção de HPV em neoplasias de pele e pele normal de indivíduos imunocompetentes e imunossuprimidos. 
Tabela 3 - Freqüência de detecção de vírus do papiloma humano pela reação em cadeia da polimerase em lesões cutâneas e pele normal.

\begin{tabular}{lcc}
\hline \hline Lesões cutâneas & Imunossuprimidos (\%) & Imunocompetentes (\%) \\
\hline \hline CEC & $54-81$ & $27-33$ \\
Doença de Bowen & $33-40$ & $67-100$ \\
QA & $33-93$ & $55-70$ \\
CBC & $33-83$ & $21-44$ \\
Pele normal & $60-73$ & $35-70$ \\
Folículos pilosos & $45-92$ & $16-76$ \\
\hline \hline
\end{tabular}

NOTA: CEC - carcinoma espinocelular; QA - queratose actínica; CBC - carcinoma basocelular;

FONTE: Sterling, 2005.

\subsection{Patogênese da infecção pelo HPV}

O HPV infecta epitélios estratificados queratinizados e não queratinizados, através de sua implantação direta quando da quebra da barreira epitelial (Vardy et al., 1990; Androphy, 1994; Favre et al., 1997; Akgül et al., 2007). Os alvos da infecção pelo HPV são as células basais dos epitélios estratificados (Favre et al., 1997). A $\alpha-6$ integrina parece ser o receptor específico do HPV (Evander et al., 1997).

O ciclo de vida do HPV acompanha o programa de diferenciação dos epitélios estratificados (Figura 6). Os vírus são produzidos apenas nos 
queratinócitos em diferenciação terminal (Androphy, 1994; Alani e Münger, 1998; Oldak et al., 2004; Haller et al., 1995). Nas células basais os genes "E" são fracamente expressos e apenas um pequeno número de cópias do genoma viral está presente. Como o HPV não possui polimerase para a replicação do seu DNA nativo, as oncoproteínas virais E6 e E7 interferem com os fatores de controle do ciclo celular e asseguram a atividade da DNApolimerase celular nas camadas suprabasais da epiderme. Desse modo retardam a diferenciação terminal dos queratinócitos (Oldak et al., 2004; Woodworth et al., 1992).

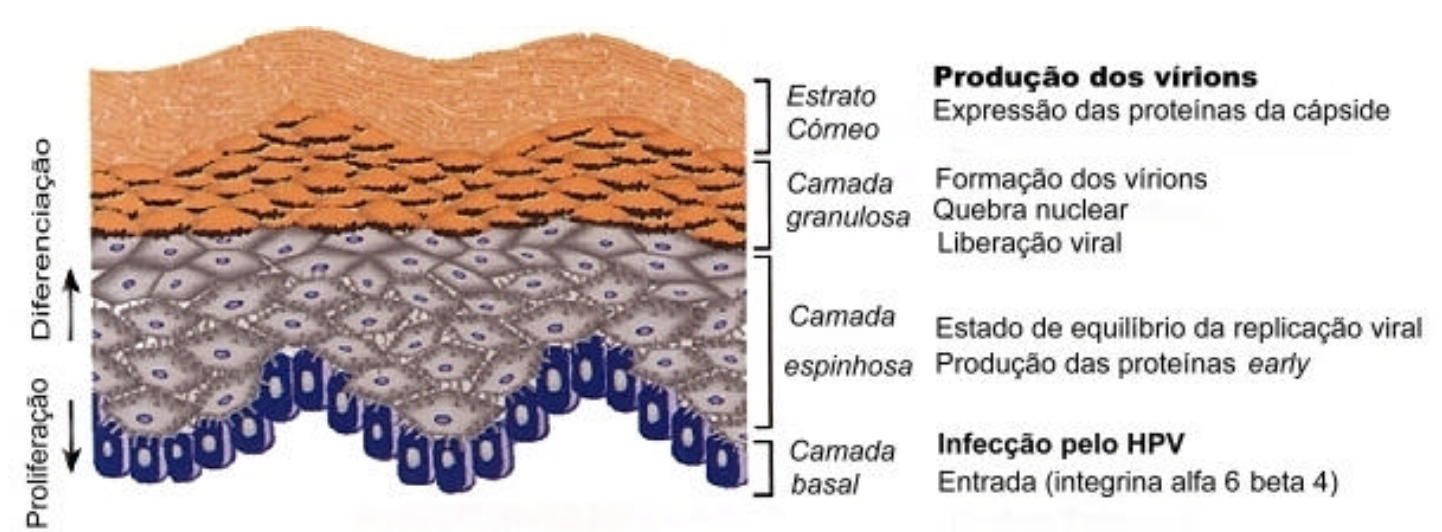

Figura 6 -

Ciclo de vida do HPV no epitélio escamoso estratificado. O HPV infecta as células basais do epitélio. Após a perda da cápside o genoma viral é transportado ao núcleo onde os genes "E" são transcritos. Na camada espinhosa há um estado de equilíbrio da replicação viral e expressão dos genes "E". As partículas virais são produzidas nas camadas superficiais do epitélio (em diferenciação terminal) (HPV: vírus do papiloma humano; E: gene early).

FONTE: Modificado de Alani e Münger, 1998.

O DNA viral está em posição extracromossômica no núcleo das células basais e, como DNA livre, precede a formação da cápside (Ostrow et 
al, 1982; Vardy et al, 1990; Majewski e Jablonska, 2006). O DNA viral extracromossômico pode persistir como pequeno número de cópias nas células basais, ou pode se replicar conjuntamente com a divisão celular normal, sendo transportados pelas células filhas às camadas superiores do epitélio, onde os ácidos ribonucléicos (RNAs) virais são expressos em níveis substanciais (Androphy, 1994). Os eventos específicos da diferenciação celular induziriam sinais estimulatórios para a transcrição viral e replicação de seu DNA (Androphy, 1994; Majewski e Jablonska, 1997a). Portanto, os HPV replicam-se em grande quantidade apenas nas células epiteliais diferenciadas terminais, que estão destinadas a se descamar (Androphy, 1994).

Após a replicação de múltiplas cópias de DNA, ocorre a sua incorporação dentro das proteínas da cápside (L1 e L2), que protegem o DNA viral nos queratinócitos terminais, assim como após sua liberação no meio ambiente. Os HPV são liberados no meio ambiente conforme as células infectadas sofrem o processo de maturação e descamação. Como os HPV não são liberados envoltos pela membrana plasmática celular, não incorporam envelope lipídico derivado desta membrana, o que os torna resistentes a injúrias externas como calor, detergentes ou dessecação (Androphy, 1994; Majewski e Jablonska, 1997a).

Os HPV não são líticos como outros vírus e não há evidências de sua disseminação por viremia ou outras rotas sistêmicas nos organismos infectados (Androphy, 1994). 
A capacidade imunogênica e características de antigenicidade são variáveis nos diferentes tipos de HPV, o que indica que diferentes determinantes antigênicos provocam diferentes graus de estimulação do sistema imunológico (Vardy et al., 1990).

\subsubsection{Fatores ambientais}

O principal fator ambiental envolvido na patogênese da EV é a radiação ultravioleta (UV), por atuar como co-fator de carcinogênese (Jablonska et al., 1972; Orth et al., 1979; Jablonska e Majewski, 2003).

A radiação UV é um dos fatores principais na gênese de lesões cutâneas pré-malignas e câncer cutâneo não-melanoma, através de efeitos mutagênicos e mecanismos imunomodulatórios (Termorshuizen et al., 2004).

Os tumores cutâneos em doentes com EV ocorrem principalmente nas áreas fotoexpostas. Indivíduos da raça negra com EV apresentam baixa prevalência de lesões malignas. Estes achados reforçam o papel da radiação UV como co-fator de carcinogênese na EV (Jacyk e Villiers, 1993; Oliveira, 1999; Oliveira et al., 2002; Caputo et al., 1995; Motegi et al., 2003).

$A$ radiação ultravioleta $B$ (UVB) provoca redução da imunidade local e sistêmica, induzindo imunossupressão específica pela alteração na apresentação de antígenos, e não específica através da liberação de 
citocinas imunossupressoras (Majewski e Jablonska, 1992; 1995; Jablonska e Majewski, 1994).

A imunossupressão na EV pode ser evidenciada pela diminuição da sensibilidade de contato ao dinitroclorobenzeno (DNCB) na pele fotoexposta (Majewski e Jablonska, 1992; 1995; Jablonska e Majewski, 1994).

$\mathrm{Na}$ EV parece haver polimorfismos no gene de susceptibilidade à radiação UVB (Majewski e Jablonska, 1992; 1995) Neste gene está incluído o lócus do fator de necrose tumoral alfa (TNF $\alpha$ ), determinando aumento na produção local desta citocina pelo estímulo da UVB (Majewski et al., 1991). Este aumento de TNF $\alpha$ altera a apresentação de antígenos com diminuição da resposta imune celular local (Majewski e Jablonska, 1992; Majewski e Jablonska, 1997a).

O ácido urocânico é o principal absorvedor da UVB no estrato córneo. A UVB determina sua isomerização da forma trans (encontrada usualmente) para a forma cis, determinando imunossupressão local por supressão das reações de hipersensibilidade tardia, estímulo de linfócitos T supressores e alteração das células apresentadoras de antígenos. A ação do ácido urocânico parece ser mediada pelo TNF $\alpha$. Nos pacientes com EV e tumores cutâneos extensos pode ocorrer um aumento da forma cis do ácido urocânico (Majewski e Jablonska, 1992; 1995; 1997a, Jablonska e Majewski, 1994).

O fator de crescimento tumoral $\beta 1$ (TGF $\beta$ 1) também se encontra elevado nas lesões benignas e malignas da EV. Essa citocina também 
participa na imunossupressão desencadeada pela exposição crônica à radiação UVB (Majewski et al., 1991; Majewski e Jablonska, 1998).

A radiação UV também apresenta efeito direto no DNA das células, causando alterações mutagênicas nos dímeros de pirimidina, pela substituição das bases nucleotídicas C? T e CC? TT. Esta é a mutação mais freqüentemente encontrada no gene p53 nos carcinomas induzidos pela exposição solar. (Jablonska e Majewski, 1994).

As proteínas E6 dos HPV 5, 10, 77 e 18 inibem o processo de apoptose em resposta ao dano pela radiação UV, sem a participação da degradação de p53 (Jackson e Storey, 2000).

A proteína BAK está envolvida na apoptose celular em resposta ao dano por UVB. Sua função é alterada por sua degradação proteolítica sob a ação das proteínas E6 dos HPV 5, 10, 77 e 18. Neoplasias cutâneas HPVpositivas apresentam níveis indetectáveis de BAK em contraste com as neoplasias HPV-negativas (Jackson et al., 2000). Como as neoplasias cutâneas associadas ao HPV, em doentes com EV ou imunossuprimidos por transplantes de órgãos, ocorrem freqüentemente em áreas fotoexpostas, a atividade antiapoptótica da E6 pode contribuir para a sobrevivência de lesões infectadas pelo HPV expostas ao dano pelo UV, induzindo e facilitando a persistência de alterações genéticas induzidas pelo UV (Jackson e Storey, 2000).

Episódios de queimadura solar entre 13 e 20 anos estão associados com soropositividade para EV-HPV. Entretanto, é descrita paradoxalmente 
que uma maior exposição solar cronicamente ao longo da vida estaria associada com menor risco de infecção por EV-HPV (Termorshuizen et al., 2004).

Diversos relatos apontam que a radioterapia é um co-carcinógeno nas lesões induzidas pelo HPV, favorecendo a maior agressividade dos tumores, inclusive com disseminação metastática (Lutzner et al., 1984; Jablonska e Majewski, 1994; Majewski e Jablonska, 1995; 1997 b; Gül et al., 2007 ).

A radioterapia induz a liberação de $\operatorname{TNF} \alpha$, que atua como co-fator na carcinogênese da EV, o que levaria a um aumento do risco de metástases nestes doentes (Jablonska e Majewski, 1994, 2003; Majewski e Jablonska, 1995; Cobb, 1990; Oliveira et al., 2002).

\subsubsection{Fatores genéticos}

O principal defeito genético na EV é uma maior susceptibilidade à infecção pelo HPV, especialmente aos tipos específicos de HPV (EV-HPV) encontrados predominantemente nos doentes de EV, e normalmente inofensivos à população em geral (Majewski e Jablonska, 1992; 1995; 1997a; 2001).

A EV pode ser familial ou esporádica (Kanda et al., 1989; Lutzner et al., 1984; Oliveira et al., 2002). Embora Androphy et al., (1985) descrevam a forma esporádica como a mais comum, Oliveira et al. (2002) somente 
encontraram a forma esporádica em três de 13 doentes estudados. Esses autores observaram consangüinidade familiar em $92 \%$ dos doentes estudados (Oliveira et al., 2002).

Apesar da maioria dos relatos apontarem para um padrão de herança autossômica recessiva da EV, outras formas de transmissão também foram relatadas (Androphy et al., 1985; Lutzner, 1978; Rajagopalan et al., 1972).

Como mais de uma forma de transmissão da EV foi descrita, as alterações genéticas responsáveis pela doença devem se localizar em pelo menos dois genes localizados em cromossomos diferentes, um dos quais poderia estar localizado no cromossomo X (Androphy et al., 1985; Majewski e Jablonska, 1995). De fato, Ramoz et al. $(1999,2000)$ identificaram dois loci de susceptibilidade para EV no cromossomo 17qter (EV1) e no cromossomo 2p21-p24 (EV2). Esses achados indicam a heterogenicidade não alélica nessa doença (Ramoz et al., 1999; 2000).

É interessante o fato de que ambos os loci pertencem a regiões que também contém loci para psoríase (Ramoz et al., 1999; 2000). É importante ressaltar que doentes com psoríase apresentam maior prevalência de anticorpos contra HPV-5 VLP (virus like particles) (Favre et al., 1998b) e maior prevalência de seqüências de DNA de EV-HPV na epiderme (Weissenborn et al., 1999). HPV-5 foi detectado em mais de 90\% dos casos de psoríase, em contraste com rara detecção deste genótipo em indivíduos normais ou com câncer cutâneo (Boxman et al., 1997; Pfister e Ter Schegget 1997; Astori et al., 1998). A proliferação dos queratinócitos na psoríase 
poderia estimular o ciclo de vida do HPV. As proteínas E6 e E7 estimulariam ainda mais o aumento da proliferação epidérmica. L1 ativaria a resposta imune mediada por células, com produção de citocinas pró-inflamatórias com conseqüente perpetuação do processo (Majewski et al., 1999; 2001; Majewski e Jablonska 2003).

No locus EV1 dois genes de susceptibilidade (EVER1 e EVER2, atualmente designados TMC6 e TMC8, respectivamente) foram identificados. Os produtos genéticos dos genes TMC6 e TMC8 têm características de proteínas integrais de membrana e estão localizados no retículo endoplasmático. Pertencem à família dos genes de canais transmembrânicos (TMC - trans membrane channel- like gene family) (Ramoz et al., 2002, Keresztes et al., 2003; Lazarczyk et al., 2008)

TMCs são proteínas com um centro de 8 domínios de cruzamento da membrana plasmática. Postula-se que constituam um novo grupo de canais iônicos, transportadores ou modificadores dos mesmos (Keresztes et al., 2003). Ainda não se sabe qual o papel destes genes na resposta imune para o controle da infecção dos queratinócitos pelo EV-HPV. Vários autores relatam mutações do TMC6 e TMC8 em pacientes de EV de diversas etnias (Tate et al., 2004; Sun et al., 2005; Aochi et al., 2007; Gober et al., 2006; Zuo et al., 2006; Berthelot et al., 2007; Rady et al., 2007). Em um artigo de revisão Orth (2006) refere que $75 \%$ dos pacientes com EV apresentam mutações de TMC6 e TMC8. 
Patel et al. (2008) evidenciam, em estudo caso-controle de pacientes com carcinomas espinocelulares (CEC), que a presença de polimorfismo no gene EVER2 estava associado com maior risco de CEC e de positividade para anticorpos contra Beta-papilomavírus.

As proteínas EVER1 e EVER2 formam complexos com o transportador de zinco (ZnT-1) com alteração da distribuição do zinco intracelular, mas não de sua concentração total. EVER e ZnT-1 também inibem a atividade do fator de transcrição regulador de metais (MTF-1), de cJun e do AP-1. Como o AP-1 é um fator de transcrição chave para os HPV, mutações em EVER poderiam facilitar a transcrição do genoma viral, particularmente de E6/7 (Lazarczyk et al., 2008).

No processo carcinogenético da EV também ocorre a participação do gene p53 de supressão tumoral. O gene p53 codifica uma das proteínas celulares mais importantes para a manutenção da estabilidade cromossômica (Padlewska et al., 2001). Anormalidades do p53 foram encontradas em neoplasias da EV (Padlewska et al., 2001; Majewski e Jablonska, 2001; 2002).

O gene p53 apresenta um polimorfismo comum no códon 72 da proteína que codifica, resultando na síntese de arginina ou prolina. O alelo relacionado à produção da arginina é um fator genético de risco para a carcinogênese nos doentes de EV (de Oliveira et al., 2004a). 
O p53 diminui a replicação do DNA do HPV 8, mas ativa o promoter do oncogene E6, o que indica seu papel controlador do equilíbrio entre a replicação viral e a expressão gênica do HPV8 (Akgül et al., 2003).

\subsubsection{Aspectos imunológicos}

A resposta imunológica ao HPV é geneticamente determinada, envolvendo tanto a imunidade humoral quanto a celular. É dependente da apresentação dos antígenos virais aos linfócitos $\mathrm{T}$ pelas células apresentadoras de antígenos, em associação com as moléculas do complexo principal de histocompatibilidade (MHC) (Majewski e Jablonska, 1998; Malejczyk et al., 1997). Foram demonstradas associações dos haplótipos DR e DQ da classe II do MHC com a EV (Majewski e Jablonska, 1995; 1997a; 1998).

A maioria dos doentes de EV apresenta alterações específicas da imunidade celular ao HPV (Guimarães et al., 1997; Majewski et al., 1986; Oliveira, 1999). Entretanto, esses doentes não apresentam respostas imunes anormais contra outras infecções virais ou microbianas (Majewski et al., 1986). Podem ocorrer alterações na imunidade humoral, mas esta não desempenha papel importante na patogênese da EV (Guimarães et al., 1997; Jablonska et al., 1979; Oliveira, 1999). 
A diminuição na imunidade celular local e específica provoca diminuição da citotoxicidade natural e inibição da proliferação dos linfócitos T contra os queratinócitos infectados pelo HPV (Cooper et al., 1990).

Alguns doentes apresentam também diminuição da imunidade celular não-específica, local e sistêmica, que podem ser secundárias à infecção crônica e generalizada pelo HPV (Haftek et al., 1985; Majewski et al., 1986). Esta diminuição da imunidade correlaciona-se com a gravidade e duração das lesões (Glinski et al., 1976, 1981).

As principais alterações da imunidade celular não-específica são a diminuição no número de linfócitos $\mathrm{T}$ periféricos, diminuição da resposta proliferativa dos mononucleares do sangue periférico aos mitógenos universais, anergia cutânea a vários antígenos comuns da pele e ausência de sensibilização ao dinitroclorobenzeno (DNCB) (Glinski et al., 1976, 1981; Haftek et al., 1985; Oliveira, 1999).

A diminuição da imunidade mediada por células se relaciona mais com o tempo de duração da doença do que com a presença de tumores (Oliveira et al., 2006)

As células natural killer (NK) têm ação citotóxica contra vírus e células neoplásicas, dispensando sensibilização prévia. A análise da função dessas células contra queratinócitos infectados com EV-HPV demonstrou diminuição da função dessa população celular (Majewski et al., 1986). Entretanto, o padrão de resposta das células NK desses doentes frente a células eritroleucêmicas K-562 apresentava padrão de resposta dentro da 
normalidade (Androphy et al., 1984). Essa disfunção específica de células NK poderia justificar parcialmente porque os portadores de EV não são mais susceptíveis a outros vírus e a infecções bacterianas e fúngicas (Kawashima, 1992).

$\mathrm{O}$ defeito da imunidade celular na EV parece estar relacionado à alteração na apresentação de antígenos do HPV pelas células apresentadoras de antígenos em ambiente cutâneo (Jablonska e Majewski, 1994; Majewski e Jablonska, 1992; 1997a; 2001). As células de Langerhans desempenham papel importante na apresentação de antígenos (Vardy et al., 1990). Na EV estas células não apresentam habitualmente alteração no seu número e função, embora possam estar pouco diminuídas em número nas lesões benignas. Esse fato poderia representar um fator adicional na depressão da imunidade local (Haftek et al., 1985; Cooper et al., 1990).

$\mathrm{Na} E V$, os queratinócitos infectados podem funcionar como células apresentadoras de antígenos "não-profissionais", o que também poderia levar a uma diminuição da imunidade na doença (Jablonska e Majewski, 1994; Malejczyk et al., 1997).

Alguns antígenos virais podem alterar a imunidade pela liberação de citocinas pelos queratinócitos infectados (Majewski e Jablonska, 1992; 1998).

As citocinas modulam a ação dos linfócitos $\mathrm{B}$ e $\mathrm{T}$, das células $\mathrm{NK}$ e interferem na proliferação e diferenciação das células epidérmicas (Majewski e Jablonska, 1992; 1998), podendo inibir a expressão do genoma viral, 
estimular a apoptose das células infectadas, estimular a migração leucocitária e diminuir a angiogênese tumoral e formação de metástases (Majewski e Jablonska, 1997a; 1998).

A produção aumentada de citocinas inibitórias como TGF $\beta 1$ e TNF $\alpha$ na epiderme de doentes com EV poderia também propiciar a diminuição da imunidade celular (Majewski et al., 1991).

O TNF $\alpha$ pode suprimir a imunidade celular local por alterar a apresentação de antígenos pelas células de Langerhans (Majewski e Jablonska, 1992). Níveis elevados de TNF $\alpha$ foram detectados em lesões de EV associados aos EV-HPV (Majewski et al., 1991).

O TGF $\beta 1$ é uma citocina com atividades estimulatórias e inibitórias para a proliferação celular (Moses et al., 1990). Está envolvida nos efeitos deletérios da imunidade cutânea, provocados pela exposição crônica à UVB. Esta citocina apresenta-se com níveis aumentados nas lesões benignas e malignas de EV (Majewski et al., 1991; Majewski e Jablonska, 1998).

O TGF $\beta 1$ diminui a atividade dos linfócitos T, a apresentação de antígenos dependente de interleucina-1 e a função das células NK. Ao estimular a produção de TNF $\alpha$, deprime ainda mais a resposta imune contra os queratinócitos infectados pelos EV-HPV (Majewski e Jablonska, 1992). Também é inibidor de proteases e promove o aumento de expressão de integrinas importantes no processo de metástases (Majewski e Jablonska, $1992 ; 1995)$. 
Oliveira et al. (2003) avaliaram o polimorfismo dos genes promotores da interleucina-10 (IL -10), citocina com efeitos supressores e estimulatórios na imunidade celular, em pacientes com EV. Demonstram maior prevalência de genótipos relacionados à baixa produção de IL-10 nestes pacientes, especialmente naqueles que apresentam neoplasias associadas.

\subsubsection{Oncogênese nos doentes com EV}

A oncogênese na EV ainda não está totalmente esclarecida. Diferentemente dos carcinomas genitais induzidos pelo HPV a E6 não inativa o p53 e a capacidade de transformação das oncoproteínas E6/7 dos EV-HPV é baixa (Majewski e Jablonska, 2006). Também é rara a integração do DNA viral ao genoma humano nos carcinomas cutâneos na EV. (Majewski e Jablonska, 1995; 2002; Padlewska et al., 2001; Pizarro et al., 1995; Pfister e Ter Schegget, 1997).

O HPV parece ser necessário, mas não suficiente, para a carcinogênese na EV, necessitando da atuação de co-fatores. O fato da transformação maligna aparentemente depender mais do tipo de HPV envolvido, e não devido às alterações da imunidade, reforça o papel carcinogênico do HPV na EV (Jablonska et al., 1978; Pyrhönen et al., 1980; Oliveira et al,. 2003). Entretanto, nem todas as lesões cutâneas da EV, mesmo as relacionadas aos HPV de alto risco, sofrem transformação 
maligna. O longo período de latência (5-20 anos) entre a infecção e o desenvolvimento das lesões malignas também sugere a necessidade da participação de co-fatores no processo de tumorigênese. (Androphy, 1994; Majewski e Jablonska, 1997b).

Os principais co-fatores oncogênicos na EV são a radiação ultravioleta (UV) (Jablonska et al., 1972; Orth et al., 1979; Jablonska e Majewski, 2003) e a radioterapia, que predispõe a maior agressivade tumoral e metástases (Lutzner et al., 1984; Jablonska e Majewski, 1994, Majewski e Jablonska 1995; 1997 b; Gül et al., 2007).

\subsubsection{Tratamento}

Embora as lesões cutâneas da EV sejam causadas por HPV, as alternativas terapêuticas usadas em verrugas virais como eletrodissecção, crioterapia, retinóides tópicos, sensibilização por contato e cirurgia são geralmente insatisfatórias (Lowy e Androphy, 1999; Guimarães et al., 1997) Não há tratamento específico para a EV, sendo as lesões extremamente resistentes às terapêuticas empregadas (Jablonska e Majewski, 1994; Guimarães et al., 1997; Gewirtzman et a.l, 2008).

Uma das poucas medidas efetivas para a prevenção das neoplasias associadas à EV é a fotoproteção (Majewski e Jablonska, 1995). 
Os tratamentos locais por destruição física das células infectadas são pouco efetivos na EV (Androphy et al., 1984; Tanigaki e Kanda, 1990). Entre os tratamentos propostos está a terapia fotodinâmica com ácido 5aminolevulínico tópico, com recidiva parcial das lesões após um ano de tratamento (Karrer et al., 1999). Imiquimod tópico pode ser utilizado isoladamente, ou associado com interferons sistêmicos para tratamento das lesões pré-malignas e malignas da EV (Baskan et al., 2006; Berthelot et al., 2007).

As neoplasias malignas devem ser excisadas (Jablonska e Majewski, 1994; Gewirtzman et al., 2008), por cirurgia convencional ou pela técnica da cirurgia micrográfica de Mohs (Bogdan et al., 2007). A cicatrização costuma ser excelente, provavelmente pela atividade do TGF $\beta$, que está aumentada nos doentes de EV (Jablonska e Majewski, 1994; Fang et al, 2008).

Quanto aos tratamentos sistêmicos, há relatos de uso de derivados do ácido retinóico (Jablonska et al., 1986; Kanerva et al., 1985; Caputo et al., 1995; Tanigaki e Kanda, 1990; Guimarães et al., 1997; Anadolu et al., 2001; Hultgren et al., 2007; Silva et al., 2006; Rallis et al., 2007), interferons (Androphy et al., 1984; Anadolu et al., 2001; Silva et al., 2006) e cimetidina (Micali et al., 2003; Oliveira et al., 2004b), todos com resultados inconsistentes.

A radioterapia é totalmente contra-indicada por ser um co-carcinógeno nas lesões induzidas pelo HPV, favorecendo a maior agressividade dos tumores, inclusive com disseminação metastática (Lutzner et al., 1984; 
Jablonska e Majewski, 1994, Majewski e Jablonska, 1995, 1997b; Gül et al., 2007).

\subsection{Citoqueratinas}

O citoesqueleto das células é formado pelos microfilamentos de actina (6nm), pelos microtúbulos $(25 \mathrm{~nm})$ e pelos filamentos intermediários (810nm), estes assim denominados por apresentarem diâmetro intermediário entre a actina e os microtúbulos (Lazarides 1980; Smack et al., 1994).

Os filamentos intermediários são divididos em:

I. citoqueratinas ácidas (tecidos epiteliais);

II. citoqueratinas neutras-básicas (tecidos epiteliais);

III. vimentina (células mesenquimais), desmina (células miogênicas), proteína ácida fibrilar glial (células gliais e astrócitos), periferina (neurônios);

IV. neurofilamentos (neurônios), $\alpha$ internexina (neurônios pré-natais);

V. lamininas nucleares (lâmina nuclear de todas as células eucarióticas);

VI. nestina (células tronco neuroepiteliais) (Moll et al., 1982; Smack et al., 1994). 
As citoqueratinas $(\mathrm{K})$ são as principais proteínas estruturais das células epiteliais (Coulombe e Omary, 2002), e apresentam associação específica com o tipo e a diferenciação celular (Moll et al., 1982). Diferentes tipos de queratinas são expressas durante a diferenciação das células epiteliais, em diferentes estágios de desenvolvimento e em diferentes tecidos epiteliais, bem como em estados patológicos e alterações no ambiente celular (Lazarides, 1980; Nagle, 1989).

A detecção de citoqueratinas em tecidos neoplásicos, por método imuno-histoquímico, apresenta diversas aplicações diagnósticas e investigativas, porque sua expressão normalmente é conservada durante a transformação maligna (Watanabe et al., 1995).

Entre as funções das citoqueratinas estão a atuação como um arcabouço, resistente, mas flexível, que permite às células epiteliais suportarem tensões mecânicas e não-mecânicas; manutenção da forma celular; posicionamento e distribuição das organelas celulares e manutenção da integridade dos contatos intercelulares. Os filamentos intermediários também conectam o núcleo com a superfície celular, podendo funcionar como mediadores da comunicação entre o espaço extracelular e o núcleo. (Goldmann et al., 1985; Coulombe e Omary, 2002; Smith, 2003). Alterações no citoesqueleto de uma célula podem influenciar as interações intercelulares e o citoesqueleto das células adjacentes (Albers e Fuchs 1989). 
As citoqueratinas apresentam um domínio alfa-helical central bastante estável com aproximadamente 310 aminoácidos, que é interrompido em quatro pontos por segmentos não helicais e domínios terminais amino e carboxil (Steinert et al., 1985; Nagle, 1989; Smack et al., 1994).

São classificadas em tipo I (ácidas) e tipo II (neutro-básicas), sendo geralmente coexpressas em pares, sendo uma do tipo ácida e uma do tipo neutro-básica (Moll et al., 1982; Smack et al., 1994) (Tabela 4). Análises genômicas recentemente demonstraram um total de 54 genes funcionais para queratinas, 28 do tipo I e 26 do tipo II, com grupamentos de 27 genes cada, nos cromossomos 17q21.2 e 12q13.13 (com o gene para K18- tipo I localizado no domínio genético de tipo II). Atualmente se sugere o uso do termo queratina ao invés de citoqueratina (Schweizer et al., 2006). 
Tabela 4 - Expressão e distribuição dos pares de citoqueratinas no tegumento humano.

\begin{tabular}{|c|c|c|c|c|}
\hline Tipo II & $\begin{array}{l}\text { Neutro- } \\
\text { básica }\end{array}$ & Tipo I & Ácida & $\begin{array}{c}\text { Distribuição e } \\
\text { expressão }\end{array}$ \\
\hline número & PM (kDa) & número & PM (kDa) & \\
\hline 1,2 & $67(68), 65$ & $10 / 11$ & $56,5 / 56$ & $\begin{array}{l}\text { Diferenciação terminal } \\
\text { cutânea }\end{array}$ \\
\hline 1,2 & $67(68), 65$ & 9 & 64 & $\begin{array}{l}\text { Diferenciação terminal } \\
\text { palmo-plantar }\end{array}$ \\
\hline 3 & $64(63)$ & 12 & 55 & Diferenciação corneal \\
\hline 4 & 59 & 13 & $51(54)$ & Diferenciação esofageana \\
\hline 5 & 58 & $14 / 15$ & 50 & $\begin{array}{l}\text { Células basais do epit. } \\
\text { escamoso estratificado }\end{array}$ \\
\hline 6 & 56 & $16 / 17$ & $48 / 46$ & $\begin{array}{l}\text { Estados proliferativos da } \\
\text { epid, epit.embrionário, } \\
\text { células em cultura }\end{array}$ \\
\hline 7 & 54 & 17 & 46 & $\begin{array}{l}\text { Epitélio simples, estadios } \\
\text { embrionários }\end{array}$ \\
\hline 8 & $52(52,5)$ & $18 / 19$ & $45 / 40$ & $\begin{array}{l}\text { Epitélio simples, estadios } \\
\text { embrionários }\end{array}$ \\
\hline
\end{tabular}

PM - peso molecular; kDa - quilodalton; epit. - epitélio; epid. - epiderme. (Modificado de Smack et al., 1994 e Moll et al., 1982).

(PM entre parênteses indica o PM descrito em Moll et al., 1982, quando diferente de Smack et al., 1994).

Na epiderme humana normal os queratinócitos seguem um padrão de maturação durante sua migração da camada basal até a camada córnea, o qual é acompanhado por mudanças na síntese das citoqueratinas (Fuchs, 1990). Induzidos por estímulos ainda não totalmente esclarecidos alguns queratinócitos basais migram da camada basal para a espinhosa, perdem sua atividade mitótica (param de se proliferar), e começam a sintetizar novas proteínas estruturais e enzimas características do processo de corneificação (Candi et al., 2005). 
Na camada basal da epiderme interanexial ocorre a expressão das citoqueratinas 5 (neutro-básica) e 14 (ácida) (Moll et al., 1982; Cribier e Grosshans 1993; Almeida Jr et al., 1994). Essas citoqueratinas são encontradas em todos os epitélios escamosos estratificados, mas não nos epitélios simples, sendo consideradas marcadoras de epitélios estratificados (Tseng et al., 1982). Sua expressão ocorre a partir da oitava semana de idade gestacional (Dale et al., 1985).

$\mathrm{Na}$ epiderme normal a expressão de K1/10 ocorre apenas nos queratinócitos suprabasais, comprometidos com o processo de diferenciação terminal (Tseng et al., 1982; Stoler et al.,1988; Almeida Jr et al., 1994). K1 e K10 estão entre as primeiras proteínas expressas no processo de corneificação, e substituem K5 e K14 (Candi et al., 2005). Na epiderme fetal aparecem paralelamente ao início da estratificação (Dale et al., 1985).

A K16 é coexpressa com a K6 na epiderme palmo-plantar e na bainha externa dos folículos pilosos, não sendo encontrada habitualmente na epiderme normal (Moll et al., 1982).

A expressão suprabasal de K6 e K16 ocorre em estados hiperproliferativos da epiderme como a psoríase (Stoler et al., 1988, Leigh et al., 1995), hiperplasias epidérmicas dos processos inflamatórios e infecciosos (Stoler et al., 1988, Kurokawa et al., 2006, Nogueira-Castañon et al., 2004) e na epiderme regenerativa (Kallioinem et al., 1995).

A K4 está presente em epitélios estratificados não queratinizados (como esôfago, língua, mucosa oral, faringe, laringe, epiglote, exocérvix 
uterina, vagina, glândulas sebáceas, glândulas axilares apócrinas), sendo característica de diferenciação do tipo "esofágica", sendo normalmente coexpressa com K13 (Moll et al., 1982; Cribier e Grosshans 1993; Leube et al., 1988). Também está presente na epiderme normal fetal, não sendo expressa na epiderme adulta normal (Dale et al., 1985; Van Muijen et al., 1987; Smack et al., 1994). Sua expressão em carcinomas espinocelulares indica imaturidade destas células, sendo um possível marcador para potencial metastático (Watanabe et al., 1995).

Alterações genéticas na expressão das citoqueratinas desencadeam diversa doenças como epidermólise bolhosa simples (K5 e 14); hiperqueratose epidermolítica (K1 e 10); queratodermia palmo-plantar epidermolítica (K1 e 9); distrofia corneana (K3 e 12); cirrose criptogênica (K8 e 18), paquioníquia congênita e esteatocistoma múltiplo (K17) (Almeida Jr, 2004; Smith, 2003).

\subsection{Involucrina}

O envelope corneificado é uma estrutura altamente insolúvel que se forma sob a membrana plasmática das células do estrato córneo durante a diferenciação terminal dos queratinócitos, responsável por promover uma barreira física para a epiderme, bem como para o controle da perda de água pela pele (Ishida-Yamamoto et al., 1997; Smack et al., 1994, Candi et al., 
2005). O envelope corneificado substitui a membrana plasmática dos queratinócitos diferenciados e é constituído de filamentos de queratina envolvidos por um amálgama insolúvel de proteínas, através de ligações cruzadas (crosslinks) mediadas pela ação da enzima transglutaminase, circundado por um envelope lipídico (Steinert e Marekov, 1995; Candi et al., 2005).

Entre as proteínas do envelope corneificado encontram-se a involucrina, a loricrina, cistatina $A$, as pequenas proteínas ricas em prolina (SPR ou SPRR: small proline-rich proteins), a filagrina, os filamentos intermediários de queratina e a elafina (Steinert e Marekov, 1995).

O nome involucrina é derivado do latin involucre, (envoltório, membrana que envolve). Possui peso molecular de 68 kDa e contém 45,8 resíduos de glutamina para cada 100 aminoácidos. É sintetizada no compartimento suprabasal da epiderme, localizando-se no citoplasma dos queratinócitos (Watt, 1983; Smack et al., 1994).

A involucrina é um dos componentes do envelope corneificado das células da camada córnea, sendo um dos primeiros marcadores de diferenciação terminal do epitélio (Watt, 1983). Apresenta estrutura alfahelical, e apresenta ligações cruzadas (crosslinks) mediadas pela transglutaminase com diversas outras proteínas estruturais, o que é consistente com a teoria de que a involucrina é um componente precoce na formação do envelope corneificado, provendo um arcabouço ao qual as 
outras proteínas se ligariam (Etoh et al., 1986; Ishida-Yamamoto et al., 1997, Candi et al., 2005).

A expressão de involucrina na epiderme fetal inicia-se na periderme e camada intermediária a partir da $14^{\mathrm{a}}$ semana de gestação. Na pele madura adulta sua expressão ocorre na camada espinhosa superior e na camada granulosa (Ishida-Yamamoto et al., 1997; Lee et al., 1998).

\subsection{Filagrina}

A filagrina, proteína de 36 kDa também chamada de proteína básica do estrato córneo, proteína rica em histidina II ou proteína agregadora de filamentos, é o principal componente dos grânulos de querato-hialina (estruturas globulares citoplasmáticas formadas pelo acúmulo de proteínas sintetizadas) presentes na camada granulosa, sendo marcador da fase terminal da queratinização epidérmica (Fleckman et al., 1985; Steinert e Marekov, 1995; Presland et al., 2001; Mc Grath, 2008). Na epiderme normal é expressa na camada granulosa (Almeida Jr, 1994). Juntamente com os filamentos intermediários constitui $80-90 \%$ da massa protéica da epiderme (Candi et al., 2005; Mc Grath, 2008).

A filagrina é formada a partir de um precursor de 500 kDa, a prófilagrina, proteína neutra altamente fosforilada. Durante o processo de corneificação ocorre a desfosforilação e a clivagem por proteólise da pró- 
filagrina para a liberação da filagrina (Smack et al., 1994; Candi et al., 2005; Mc Grath, 2008). Cada molécula de pró-filagrina contém aproximadamente 12 repetições de seqüências de filagrina (Smack et al., 1994; Mc Grath, 2008).

Entre suas funções está a agregação dos filamentos intermediários em feixes compactos (Smack et al., 1994; Presland et al., 2001; Candi et al., 2005), causando o colapso do citoesqueleto com alteração na forma celular nas camadas superiores da epiderme. A filagrina é degradada em aminoácidos hidrofílicos. É importante para a retenção de água, osmolaridade e flexibilidade do estrato córneo, bem como para a manutenção da textura da epiderme (Candi et al., 2005).

Recentemente descobriurse que mutações no gene da filagrina são a causa da ictiose vulgar, e são fatores de risco importantes para o desenvolvimento de dermatite atópica, asma associada com dermatite atópica e alergias sistêmicas (Mc Grath, 2008).

Estudos experimentais evidenciaram que a expressão precoce de filagrina causa rompimento de queratina e outros elementos do citoesqueleto, perda de algumas proteínas desmossômicas e inibição do crescimento celular por interrupção do ciclo celular (Presland et al., 2001) 


\subsection{E-caderinas}

As e-caderinas são glicoproteínas transmembrânicas cálcio dependentes, de peso molecular de $120 \mathrm{kDa}$, que regulam ligações homotípicas entre as células. Localizam-se nas junções aderentes apresentando um domínio citoplasmático que se liga aos filamentos de actina através das cateninas (Tada el al., 1996; Christofori e Semb, 1999; Okegawa et al., 2002; Lyakhovitsky et al., 2004).

As caderinas clássicas são denomidas e-caderina (epitelial), ncaderina (dos tecidos derivados do neuroectoderma e mesoderma) e pcaderina (da placenta, epitélio pulmonar, células basais da epiderme e células mioepiteliais mamárias) (Okegawa et al., 2002).

As caderinas também afetam várias funções celulares incluindo ativação de vias sinalizadoras (signalling pathways), regulação do citoesqueleto e controle da polaridade celular. Por fazer uma ponte entre a adesão intercelular e o citoesqueleto a e-caderina cria uma rede transcelular que permitem que grupos de células ou tecidos coordenem seu comportamento (Tunggal et al., 2005).

As e-caderinas apresentam papel importante na diferenciação epidérmica (Hines et al., 1999). Sua expressão na epiderme fetal inicia-se a partir do estágio de periderme (aproximadamente 8 a 9 semanas de idade gestacional) com positividade em todas as camadas da epiderme (Lourenço et al., 2008). 
Em estudos com anticorpos monoclonais anti-e-caderina observourse intensa expressão intercelular de e-caderina na pele normal adulta, incluindo a epiderme, o epitélio folicular e glândulas sudoríparas, e ausência de expressão na camada córnea (Tada et al., 1996; Lourenço et al., 2008).

Durante o desenvolvimento da maioria dos tumores epiteliais ocorre perda da adesão intercelular mediada pela e-caderina, induzindo invasão de células tumorais e metástases (Tada et al., 1996; Christofori e Semb, 1999; Conacci-Sorrel et al., 2002; Papadavid et al., 2002).

\subsection{Citoqueratinas, involucrina, filagrina, e-caderina e HPV}

A infecção pelo HPV pode alterar a expressão das citoqueratinas epidérmicas. Estudos demonstraram diminuição na expressão de K1 em verrugas planas (Staquet et al., 1981) e diminuição de K1 e K10 em condilomas acuminados (Mullink et al., 1991).

A expressão de involucrina também é alterada em células imortalizadas pelo HPV, onde ocorre expressão mais precoce (Woodworth et al., 1990).

Estudos in vitro evidenciaram que a infecção pelo HPV altera a expressão de e-caderina (Wilding et al., 1996; Papadavid et al., 2002; Mathews et al., 2003), bem como de filagrina (Viac et al., 1989; GuerinReverchon et al., 1990). 
Entretanto, não foram encontramos na literatura relatos sobre o perfil de expressão epidérmica das citoqueratinas, involucrina, filagrina e ecaderina nas verrugas planas associadas à EV. 
MÉTOdO 


\section{MÉTODO}

\subsection{Casuística}

Este trabalho foi realizado no Departamento de Dermatologia da Faculdade de Medicina e Divisão de Clínica Dermatológica do Hospital das Clínicas da Faculdade de Medicina da Universidade de São Paulo (HCFMUSP).

O protocolo de pesquisa (número 101/05) foi aprovado pela Comissão de Ética para Análise de Projetos de Pesquisa (CAPPesq) da Diretoria Clínica do Hospital das Clínicas e da Faculdade de Medicina da Universidade de São Paulo, em 24 de março de 2005, conforme Anexo 1.

Espécimes de lesões do tipo verruga plana de doentes com diagnóstico clínico e histopatológico de epidermodisplasia verruciforme (EV) e de doentes com verrugas planas comuns (VP) não imunossuprimidos foram levantados do arquivo do Laboratório de Dermatopatologia da Divisão de Clínica Dermatológica do HC-FMUSP, no período compreendido entre 1992 e 2006. 
Os dados clínico-epidermiológicos dos doentes foram obtidos pela consulta de seus prontuários, sendo excluídos os casos de lesões de doentes imunossuprimidos (lupus eritematoso, transplantados de órgãos e com síndrome da imunodeficiência adquirida - AIDS).

No total foram analisados 14 casos de verrugas planas de doentes sem EV e 15 casos de lesões de verruga plana de doentes com EV.

O grupo de VP foi composto por 14 pacientes, seis homens e oito mulheres, com idades entre 5 e 75 anos (média de 32,6 anos).

O grupo de pacientes com lesões do tipo verruga plana na EV foi composto por sete homens e oito mulheres, com idades entre 20 e 53 anos (média de 33,3 anos).

Os dados dos pacientes (sexo, idade, localização da lesão) encontram-se no Anexo 2, e os dados referentes aos seis casos de EV com tumores cutâneos malignos encontram-se no Anexo 3.

Para controle da expressão das citoqueratinas, involucrina, filagrina e e-caderina utilizaram-se 10 espécimes de pele sã obtidos de produtos de mamoplastias e abdominoplastias. Esses espécimes eram todos de pacientes do sexo feminino, com média de idade de 38,8 anos. 


\subsection{Análise histopatológica}

Os cortes histológicos dos espécimes corados pela hematoxilinaeosina foram analisados para a confirmação diagnóstica de verruga plana, e para a classificação do tipo de verruga plana (EV ou comum), de acordo com os critérios de Nuovo e Ishag (2000).

\subsection{Técnica imuno-histoquímica para a demonstração da expressão de citoqueratinas, involucrina, filagrina e e-caderina}

Cortes histológicos de $4 \mu \mathrm{m}$ foram colhidos em lâminas de vidro previamente tratadas com solução adesiva de aminopropyl-triethoxysilane (Sigma Chemical Co., St. Louis, MO/USA, cód A3648), na concentração de $3 \%$ em acetona PA.

Os preparados histológicos foram submetidos à reação de imunohistoquímica utilizando o método de detecção estreptoavidina-biotina (Kit LSAB+, Dako, Glostrup, Denmark) de acordo com o seguinte protocolo:

1. Desparafinização em dois banhos de xilol, um à $58^{\circ} \mathrm{C}$ durante 25 minutos e outro à temperatura ambiente por 15 minutos. 
2. Hidratação através de cadeia descendente de etanol 100\%, 95\% e $70 \%$ por 20 segundos cada.

3. Lavagem em água destilada por 5 minutos.

4. Pré-tratamento das secções histológicas para recuperação antigênica utilizando solução de Ácido Cítrico Monohidratado (Merck, Germany) $\mathrm{C}_{6} \mathrm{H}_{8} \mathrm{O}_{7} . \mathrm{H}_{2} \mathrm{O}, 0,01 \mathrm{M}$, pH6,0 e aquecido em forno de microondas (Marca Continental, 27 litros, 127V, $60 \mathrm{~Hz}$, freqüência de $2450 \mathrm{MHz}$ ), por dois ciclos de 10 minutos em potência máxima.

5. Resfriamento das lâminas por 20 minutos à temperatura ambiente.

6. Lavagem em água corrente por 10 minutos.

7. Bloqueio da peroxidase endógena através de duas incubações com solução de peróxido de hidrogênio a 3\% em água destilada de 10 minutos cada, em câmera escura.

8. Lavagens sucessivas em água corrente (5 minutos) e água destilada (5 minutos).

9. Bloqueio de ligações inespecíficas com leite em pó desnatado (Molico, Nestlé @) 10\% durante 20 minutos à temperatura ambiente.

10. Incubação com os anticorpos primários (anticorpos utilizados, clones, fabricantes e diluições apresentados na tabela 5). Os anticorpos foram diluídos em solução de albumina bovina (BSA) 1\%, (código A6003, Sigma, St. Louis, MO, USA) em câmera úmida à temperatura de $4^{\circ} \mathrm{C}$, por um período de 12 horas. 
11. Lavagem em solução tampão Tris-HCL, pH 7,4 - 7,6, por cinco minutos, por três vezes.

12. Incubação com anticorpo secundário biotinilado para anticorpos de camundongo e coelho (Kit LSAB+. DAKO Corporation, Carpinteria, CA/USA, cód. K0690) em diluição pronta para uso em câmera úmida à temperatura ambiente por 30 minutos.

13. Lavagem em tampão Tris-HCL, $\mathrm{pH} 7,4-7,6$, por cinco minutos, por três vezes.

14. Incubação com o complexo streptoavidina-biotina (LSAB+) em câmera úmida à temperatura ambiente por 30 minutos;

15. Lavagem em solução tampão Tris-HCL, pH 7,4 - 7,6, por cinco minutos, por três vezes.

16. Revelação da reação com $60 \mathrm{mg}$ de 3’3 Diaminobenzidina (DAB) (Sigma Chemical, St. Louis, MO, USA, cód. D5637) diluídos em 100ml de Tris-HCL, acrescido de $600 \mu \mathrm{L}$ de peróxido de Hidrogênio a 6\%, com controle da revelação pela observação ao microscópio óptico, até atingir a coloração castanho -dourada.

17. Lavagem em solução tampão Tris-HCL, pH 7,4 - 7,6, por cinco minutos, por três vezes.

18. Lavagem em água destilada durante 5 minutos.

19. Contra-coloração com hematoxilina de Harris por 1 minuto.

20. Lavagem em água destilada durante 5 minutos. 
21. Desidratação dos cortes histológicos através de cadeia ascendente de etanol $70 \%$, 95\% e 100\% e clarificação em dois banhos de xilol.

22. Montagem em resina Permount (Fisher Scientific, Fair Lawn, NJ /USA cód SP15-100) com lamínula de vidro, para leitura em microscópio óptico.

Tabela 5 - Anticorpos primários, clones, fabricante e diluição utilizados no estudo.

\begin{tabular}{|c|c|c|c|}
\hline $\begin{array}{l}\text { Anticorpo } \\
\text { primário }\end{array}$ & Clone & Fabricante & Diluição \\
\hline Citoqueratina 1 & $34_{\beta} \mathrm{B}_{4}$ & $\begin{array}{l}\text { Novocastra Laboratories Ltd } \\
\text { (Newcastle upon Tyne, NE, UK) }\end{array}$ & $1: 20$ \\
\hline Citoqueratina10 & LHP1 & $\begin{array}{l}\text { Novocastra Laboratories Ltd } \\
\text { (Newcastle upon Tyne, NE, UK) }\end{array}$ & $1: 20$ \\
\hline Citoqueratina 14 & LL002 & $\begin{array}{l}\text { Labvision Corporation (Fremont, CA, } \\
\text { USA) }\end{array}$ & $1: 50$ \\
\hline Citoqueratina 16 & LL025 & $\begin{array}{l}\text { Novocastra Laboratories Ltd } \\
\text { (Newcastle upon Tyne, NE, UK) }\end{array}$ & $1: 20$ \\
\hline Citoqueratina 4 & $6 \mathrm{~B} 10$ & $\begin{array}{l}\text { Novocastra Laboratories Ltd } \\
\text { (Newcastle upon Tyne, NE, UK) }\end{array}$ & $1: 100$ \\
\hline Involucrina & SY5 & $\begin{array}{l}\text { Novocas tra Laboratories Ltd } \\
\text { (Newcastle upon Tyne, NE, UK) }\end{array}$ & $1: 200$ \\
\hline Filagrina & $15 \mathrm{C} 10$ & $\begin{array}{l}\text { Novocastra Laboratories Ltd } \\
\text { (Newcastle upon Tyne, NE, UK) }\end{array}$ & $1: 100$ \\
\hline E-caderina & 36B5 & $\begin{array}{l}\text { Novocastra Laboratories Ltd } \\
\text { (Newcastle upon Tyne, NE, UK) }\end{array}$ & $1: 100$ \\
\hline
\end{tabular}

Foram utilizados como controles das reações fragmentos de pele normal (para expressão de citoqueratinas, involucrina, filagrina e ecaderina), fragmentos de lesão de psoríase (para a expressão de K 16) e fragmentos de amígdala para a expressão de citoqueratina 4 . 
O controle negativo das reações foi feito pela omissão dos anticorpos primários nas reações.

\subsection{Análise qualitativa}

Todas as lâminas foram analisadas sob microscópio óptico convencional acoplado à câmera digital para documentação dos resultados. A análise das reações foi feita pela observação da presença ou ausência de coloração, não se levando em consideração a intensidade da reação.

As citoqueratinas, involucrina e filagrina foram consideradas positivas na epiderme quando o citoplasma dos queratinócitos apresentava coloração marrom-dourada. A estratificação topográfica da epiderme considerada no presente estudo está apresentada na Figura 7. O padrão de expressão nas diferentes camadas da epiderme foi considerado difuso (se positividade em todo o segmento de epiderme representado) ou focal.

A e-caderina foi considerada positiva quando presente coloração marrom-dourada na membrana citoplasmática dos queratinócitos com padrão intercelular. 


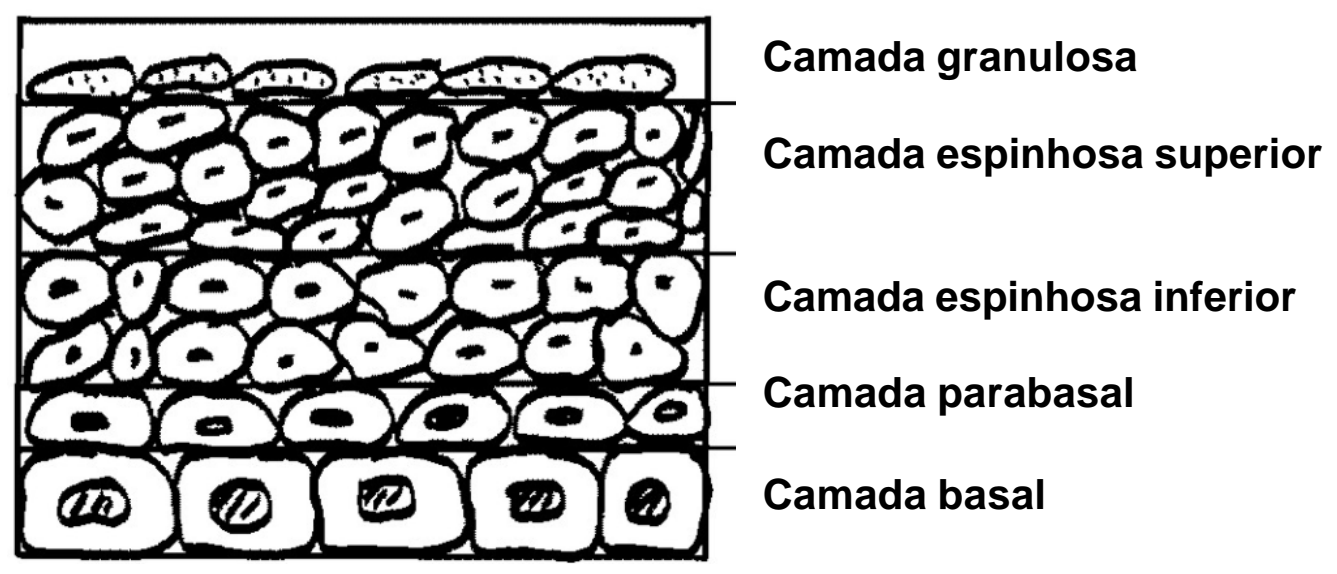

Figura 7 - Esquema com estratificação topográfica da epiderme considerada no presente estudo.

\subsection{Análise estatística}

Os resultados obtidos nos grupos de verruga plana e epidermodisplasia verruciforme foram comparados pelos testes não paramétricos do qui-quadrado e teste exato de Fisher, utilizando o software GraphPad Prism, versão 3.00 para Windows (GraphPad Software, San Diego, CA, USA). Estabeleceu-se o nível de significância de 95\% $(p=0,05)$. 
RESULTADOS 


\section{$5 \quad$ RESULTADOS}

\subsection{Caracterização da casuística}

Os dados clínicos e localização das lesões dos 14 doentes com verruga plana (VP) e dos 15 doentes com epidermodisplasia verruciforme (EV) encontram-se no A nexo 2.

No grupo de doentes com verrugas planas, $78,57 \%$ das lesões eram em áreas fotoexpostas (face, pescoço e membros superiores); $14,28 \%$ em áreas não-fotoexpostas (membros inferiores) e 7,14\% em local não especificado.

No grupo de EV $40 \%$ das lesões localizavam-se em áreas fotoexpostas (face, pescoço e membros superiores), 53,33\% em áreas não fotoexpostas (tronco e membros inferiores) e 6,66\% em local não especificado.

Os dados referentes à localização das lesões com relação à fotoexposição encontram-se na Tabela 6 . 
Tabela 6 - Localização topográfica das lesões com relação à exposição solar.

\begin{tabular}{lcccc}
\hline \hline & EV (\%) & Local/n & VP & Local/ $\mathbf{n}^{\circ}$ \\
\hline \hline Fotoexposta & $40 \%$ & $\begin{array}{c}\text { Face/pescoço (2) } \\
\text { MMSS (4) }\end{array}$ & $78,57 \%$ & $\begin{array}{c}\text { Face } / \text { pescoço (3) } \\
\text { MMSS (8) }\end{array}$ \\
& & & & \\
$\begin{array}{l}\text { Não } \\
\text { fotoexposta }\end{array}$ & $53,33 \%$ & $\begin{array}{c}\text { MMII (1) } \\
\text { Tronco (7) }\end{array}$ & $14,28 \%$ & MMII (2) \\
$\begin{array}{l}\text { Não } \\
\text { especificado }\end{array}$ & $6,66 \%$ & $(1)$ & & Tronco (0) \\
\hline Total & & 15 & $7,14 \%$ & $(1)$ \\
\hline \hline
\end{tabular}

EV: epidermodisplasia verruciformis; VP: verruga plana; MMSS: membros superiores; MMII: membros inferiores.

Entre os 15 pacientes com EV, 6 (40\%) apresentavam tumores cutâneos associados, 6 (40\%) não apresentavam tumores e em 3 (20\%) este dado não estava especificado nos prontuários analisados, assim como nos seus respectivos históricos de exames anatomopatológicos (Anexo 3).

\subsection{Análise histopatológica}

Os espécimes de verruga plana não associados à EV apresentaram, ao exame histopatológico, epiderme com hiperqueratose e acantose 
associadas a leve papilomatose. Nas camadas espinhosa superior e granulosa observourse queratinócitos coilocitóticos (Figura 8 ).

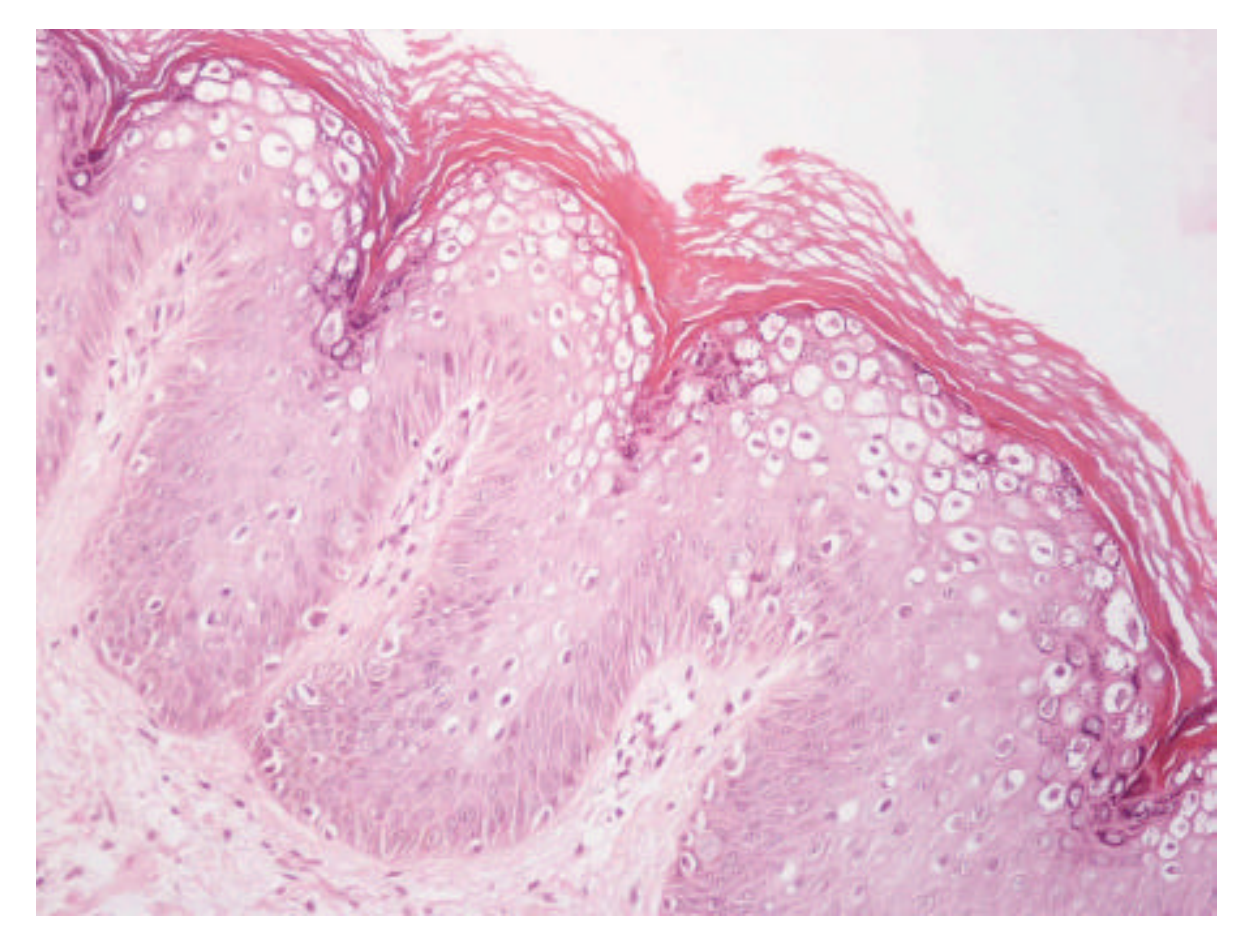

Figura 8 - Verruga plana, histopatologia. Epiderme com hiperqueratose, acantose, leve papilomatose e queratinócitos coilocitóticos nas camadas granulosa e espinhosa superior. (Hematoxilina e eosina; x200).

As lesões de verruga plana da EV exibiram epiderme com acantose e hiperqueratose leve a moderada. Os queratinócitos nas áreas acantóticas apresentaram-se aumentados de tamanho, com halos claros perinucleares e citoplasma de tonalidade cinza-azulada. Essas alterações, por vezes focais, foram observadas em toda a espessura das camadas espinhosa e granulosa da epiderme (Figura 9). 


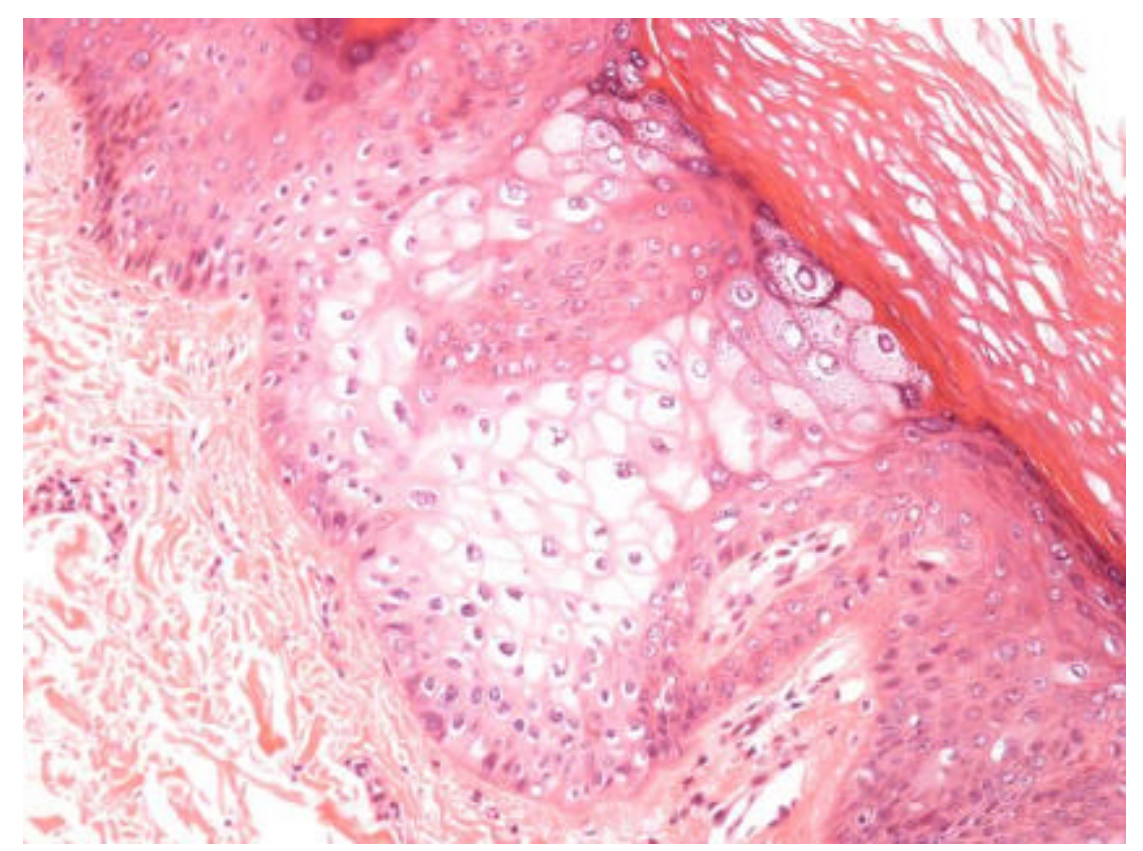

Figura 9 - Epidermodisplasia verruciforme, histopatologia de lesão do tipo verruga plana. Epiderme com acantose e hiperqueratose moderadas; células acantóticas com aumento de volume, halo perinuclear e citoplasma cinza-azulado; com grânulos de querato-hialina irregulares. (Hematoxilina e eosina; x200).

5.3 Expressão das citoqueratinas, involucrina, filagrina e e-caderina nos espécimes controle

Todos os espécimes de pele controle apresentaram o padrão normal de expressão das citoqueratinas 1 (Figura 10 A), 10 (Figura 11 A), 14 (Figura $12 \mathrm{~A}$ ), involucrina (Figura $16 \mathrm{~A}$ ), filagrina (Figura $17 \mathrm{~A}$ ) e e-caderina (Figura 18 A), conforme a Tabela 7. As citoqueratinas 4 e 16 não foram expressas na pele normal. As figuras relativas às marcações imuno-histoquímicas na 
pele normal encontram-se agrupadas juntamente com as figuras de verrugas planas e EV adiante no texto.

Tabela 7 - Expressão de citoqueratinas 1, 10, 14, involucrina, filagrina e e caderina na epiderme de grupo controle de pele normal.

\begin{tabular}{lcccc}
\hline \hline $\begin{array}{c}\text { Camada } \\
\text { Epidérmica }\end{array}$ & Basal & Espinhosa & Granulosa & $\begin{array}{c}\text { Basal / } \\
\text { Espinhosa }\end{array}$ \\
\hline Padrão & Citoplasmático & Citoplasmático & Citoplasmático & Intercelular \\
\hline \hline K1 & - & + & - & - \\
K10 & - & + & - & - \\
K 14 & + & - & - & - \\
INVOLUCRINA & - & - & + & - \\
FILAGRINA & - & - & + & + \\
E-CADERINA & - & - & - & + \\
\hline \hline
\end{tabular}

$\mathrm{K}=$ citoqueratina

\subsubsection{Expressão de citoqueratinas nas verrugas planas e na EV}

\subsubsection{Citoqueratinas 1, 10 e 14}

A expressão das citoqueratinas 1, 10 e 14 está alterada, especialmente nas lesões de epidermodisplasia verruciforme. 
Em $84,61 \%$ dos casos de verruga plana (Figura 10 B) e $26,66 \%$ dos casos de EV (Figura $10 \mathrm{C}$ ) a expressão de $\mathrm{K} 1$ ocorreu em toda a camada espinhosa da epiderme. Entretanto, a expressão de $\mathrm{K} 1$ foi observada apenas na camada espinhosa mais superficial em $53,33 \%$ dos casos de verruga plana e em 15, 38\% dos casos de EV. Em $20 \%$ das lesões de EV houve expressão apenas focal de K1.
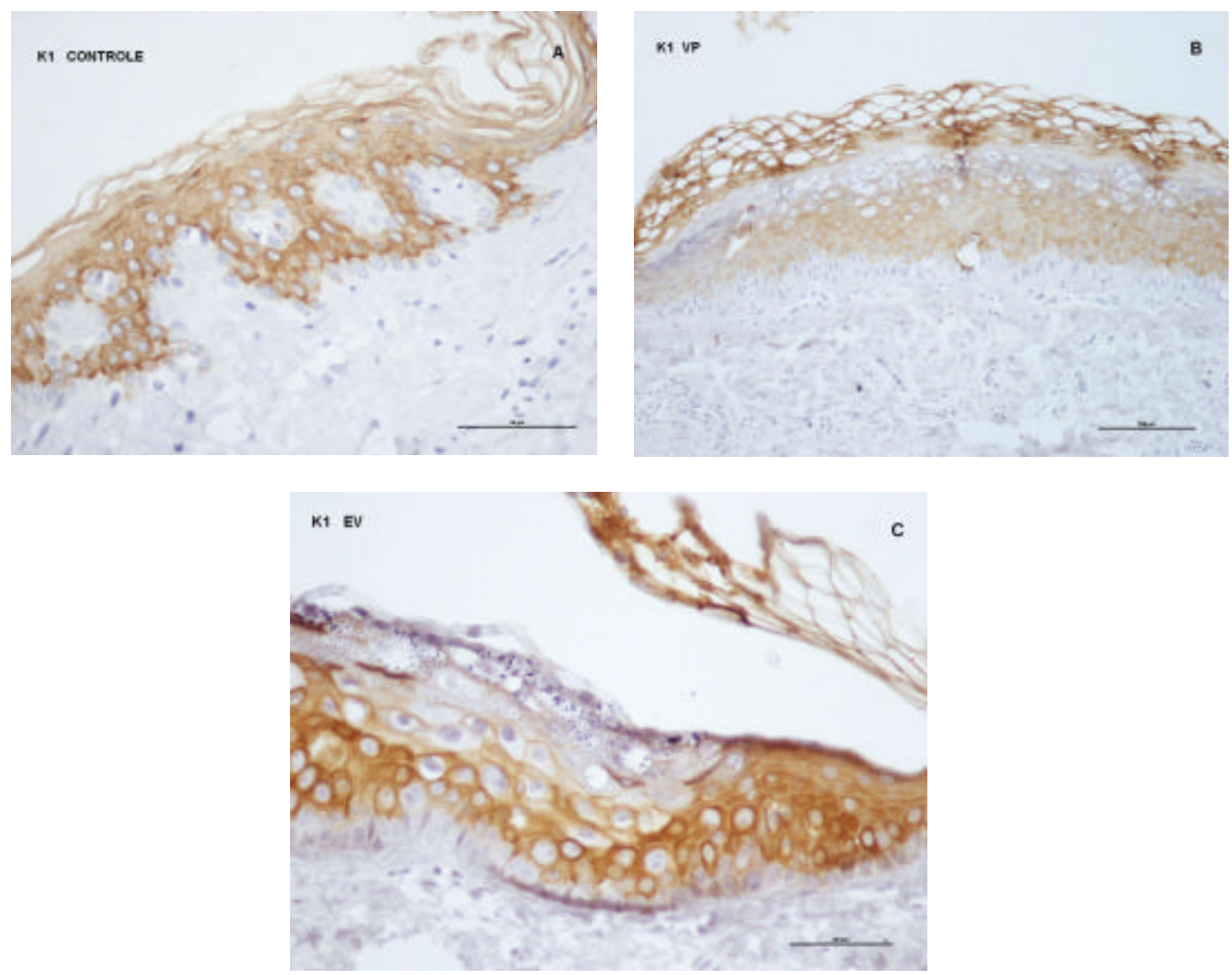

Figura 10 - Expressão de citoqueratina $1(\mathrm{~K} 1)$ em toda camada espinhosa, (A) epiderme normal -controle, (x200); (B) verruga plana (VP) (x100), (C) lesão do tipo verruga plana na epidermodisplasia verruciforme (EV) (x200). (técnica da estreptoavidina-biotina-peroxidase). 
A Tabela 8 demonstra o padrão de expressão de $\mathrm{K} 1$ em ambos os grupos.

Tabela 8 - Padrão de expressão da citoqueratina 1 nas verrugas planas e nas lesões de epidermodisplasia verruciforme.

\begin{tabular}{ccccccc}
\hline \hline & \multicolumn{2}{c}{ Espinhosa total } & \multicolumn{2}{c}{ Espinhosa superior } & \multicolumn{2}{c}{ Espinhosa focal } \\
\cline { 2 - 7 } & $\mathbf{n}$ & $\%$ & $\mathbf{n}$ & $\%$ & $\mathbf{n}$ & $\%$ \\
\hline \hline VP & $11 / 13$ & 84,61 & $2 / 13$ & 15,38 & $0 / 13$ & 0 \\
EV & $4 / 15$ & 26,66 & $8 / 15$ & 53,33 & $3 / 15$ & 20,00 \\
\hline \hline
\end{tabular}

VP: verruga plana; EV: epidermodisplasia verruciforme (teste do Quiquadrado: $p<0,001$ ).

O padrão de expressão da K10 foi marcadamente alterado nas lesões de EV, conforme a Tabela 9. Em 92,20\% dos casos de verrugas planas (Figura 11 B) e em apenas $26,66 \%$ dos casos de EV, observou-se o padrão normal de expressão de $\mathrm{K} 10$, ou seja, em toda a espessura da camada espinhosa da epiderme. A expressão epidérmica de K10 ocorreu apenas nos queratinócitos da camada espinhosa mais superficial em 7,69\% das verrugas planas e em 40\% das lesões de EV (Figura $11 \mathrm{C}$ ). Houve ausência de expressão de $\mathrm{K} 10$ em $33,33 \%$ dos casos de $\mathrm{EV}$. 
Tabela 9 - Padrão de expressão da citoqueratina 10 nas verrugas planas e nas lesões de epidermodisplasia verruciforme.

\begin{tabular}{ccccccc}
\hline \hline & \multicolumn{2}{c}{ Espinhosa total } & \multicolumn{2}{c}{$\begin{array}{c}\text { Espinhosa } \\
\text { superior }\end{array}$} & \multicolumn{2}{c}{ Negativa } \\
\cline { 2 - 7 } & $\mathbf{n}$ & $\%$ & $\mathbf{n}$ & $\%$ & $\mathbf{n}$ & $\%$ \\
\hline \hline VP & $12 / 13$ & 92,30 & $1 / 13$ & 7,69 & $0 / 13$ & 0 \\
EV & $4 / 15$ & 26,66 & $6 / 15$ & 40,00 & $5 / 15$ & 33,33 \\
\hline \hline
\end{tabular}

VP: verruga plana; EV: epidermodisplasia verruciforme (teste do Qui-quadrado $p<0,01$ ).
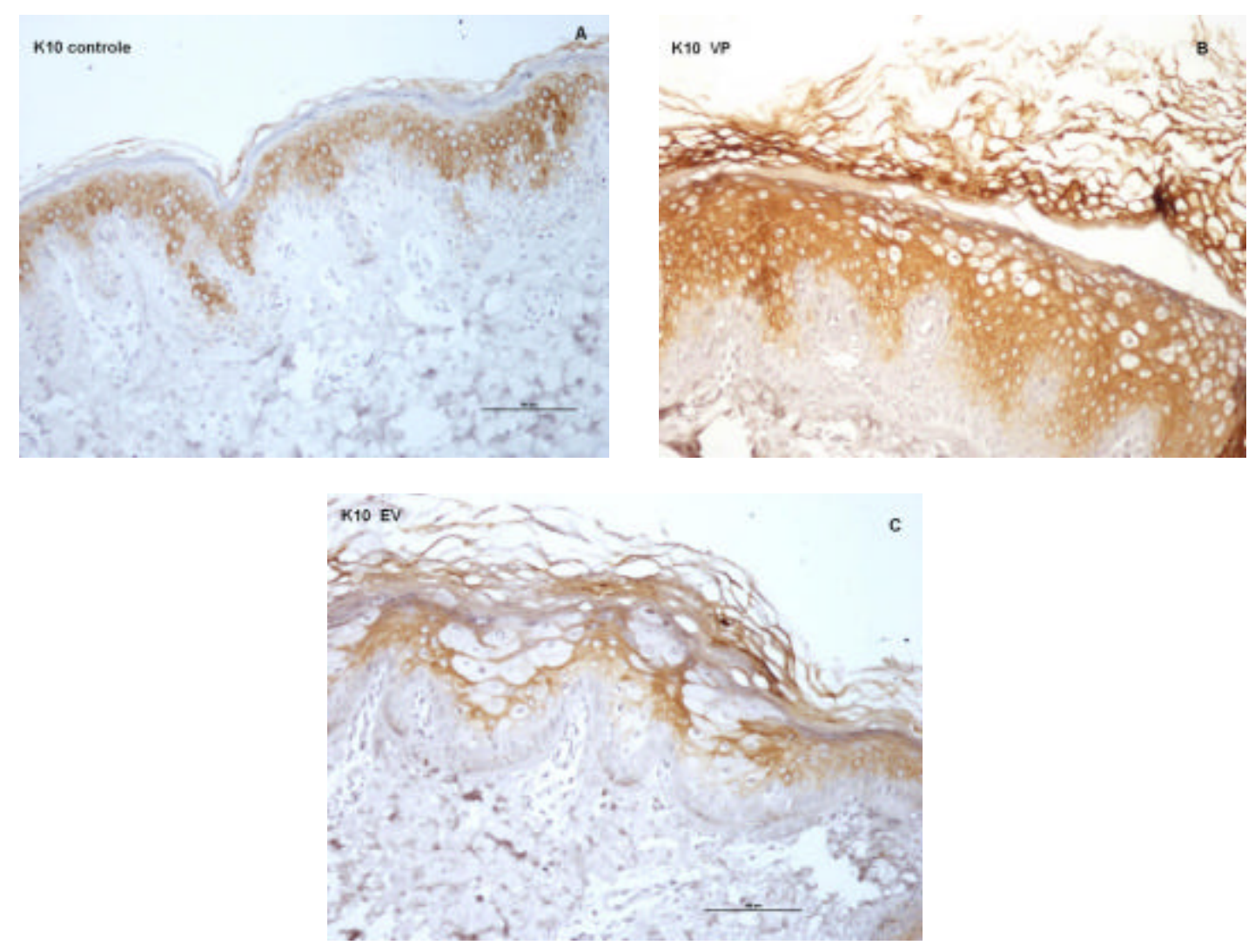

Figura 11 - Expressão de citoqueratina 10 (K10) em toda a camada espinhosa na (A) epiderme normal - controle (x100) e (B) verruga plana (VP) (x100). (C) Expressão de K10 apenas na camada espinhosa superior na epidermodisplasia verruciforme (EV) (x100) (técnica de estreptoavidina-biotina-peroxidase). 
Todas as lesões de VP e de EV apresentaram expressão de K14 nas camadas basais e parabasais da epiderme. Foi observada acentuada expressão de $\mathrm{K} 14$ em toda espessura da camada espinhosa em 42,85\% dos casos de verrugas planas (Figura 12 B) e em 100\% dos casos de EV (Figura 12 C). A Tabela 10 demonstra a comparação da expressão de K14 entre os dois grupos.

Tabela 10 - Padrão de expressão da citoqueratina 14 nas verrugas planas e nas lesões de epidermodisplasia verruciforme.

\begin{tabular}{ccccc}
\hline \hline & \multicolumn{2}{c}{ Basal e parabasal } & \multicolumn{2}{c}{ Basal e espinhosa } \\
\cline { 2 - 5 } & $\mathbf{n}$ & $\%$ & $\mathbf{n}$ & $\%$ \\
\hline \hline VP & $8 / 14$ & 57,14 & $6 / 14$ & 42,85 \\
EV & $0 / 14$ & 0 & $14 / 14$ & 100 \\
\hline \hline
\end{tabular}

VP: verruga plana; EV: epidermodisplasia Verruciforme (teste exato de Fisher $\mathrm{p}<0,01$ ). 

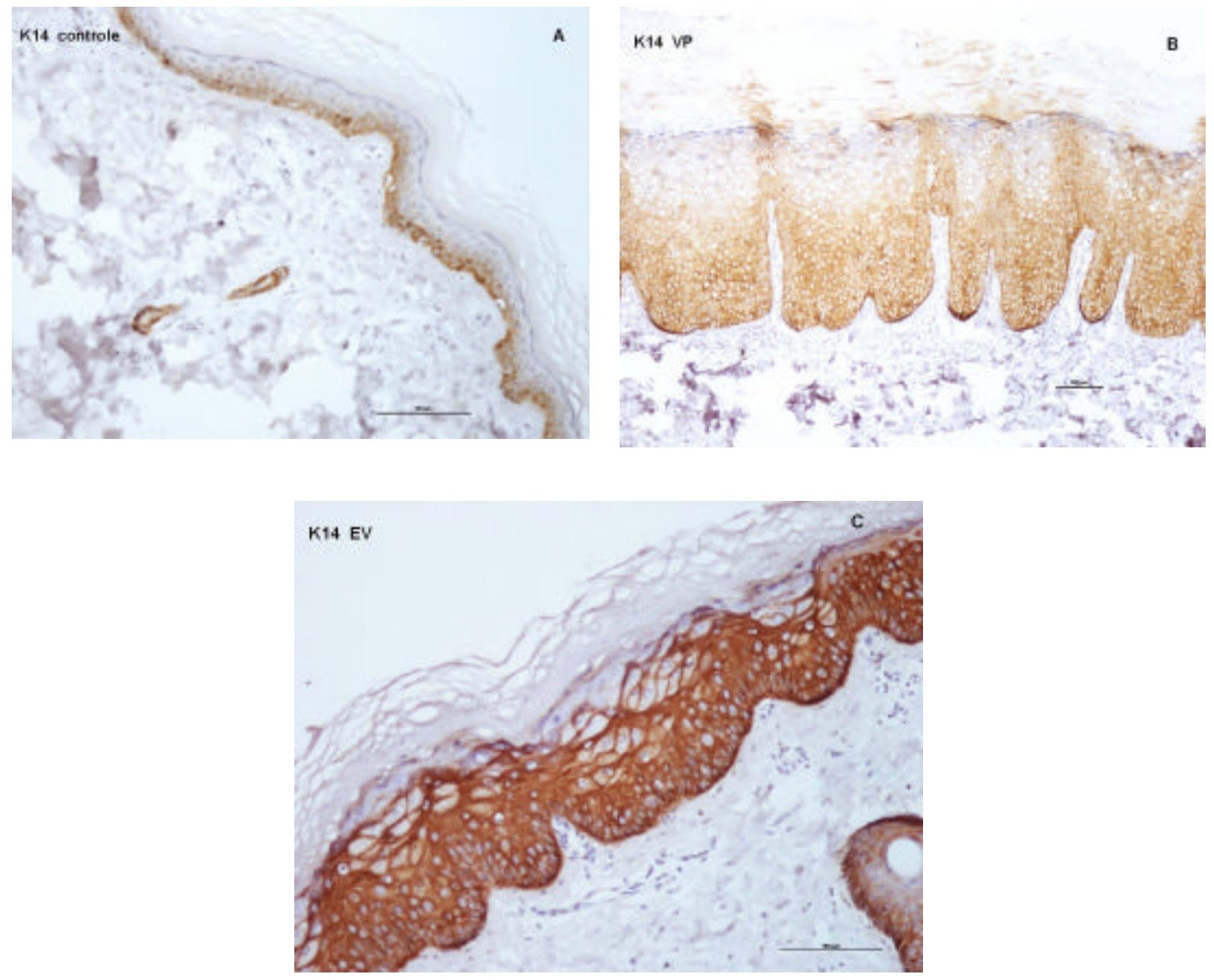

Figura 12 - (A) Expressão de citoqueratina 14 (K14) apenas nas camadas basal e parabasal na epiderme normal - controle (x100). (B) Expressão de K14 nas camadas basal, parabasal e espinhosa inferior na verruga plana (VP) (x100). (C) Expressão de $\mathrm{K} 14$ em toda a epiderme na epidermodisplasia verruciforme (EV) (x200) (técnica de estreptoavidina-biotinaperoxidase). 
Em todos os oito casos de EV que exibiram expressão retardada de K1 (expressão de K1 somente nas camadas mais superficiais da epiderme) e nos casos com expressão retardada ou negativa de K10, a expressão de K14 foi mantida em todas as camadas da epiderme. Essas alterações concomitantes em um único caso estão representadas na Figura 13 A, B e C. A pele normal adjacente, representada em quatro casos de EV, apresentou o padrão habitual de expressão de K1, 10 e 14.
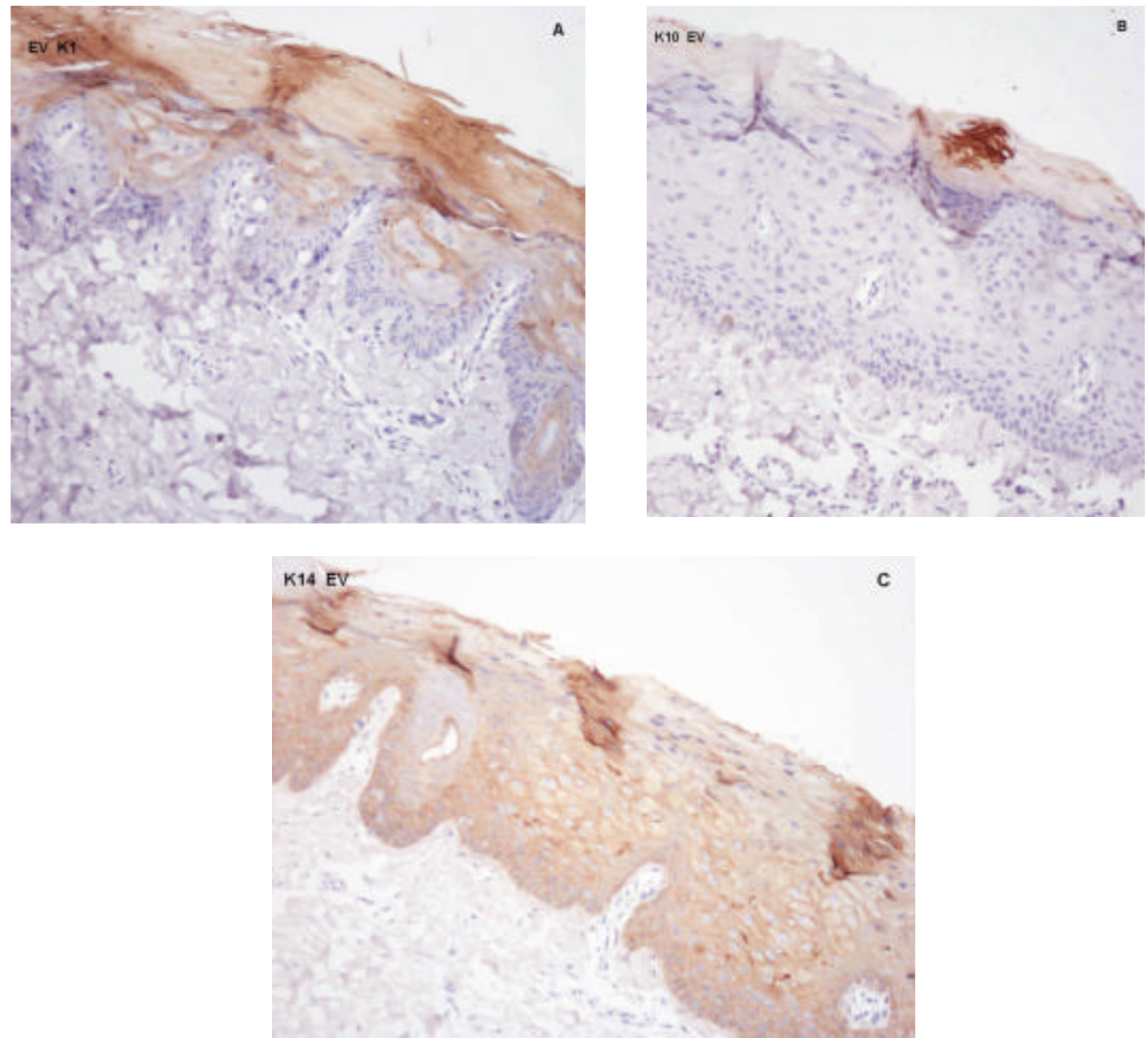

Figura 13 - Epidermodisplasia verruciforme (EV). (A) Expressão de citoqueratina 1 (K1) apenas na camada espinhosa superior (x100). (B) Expressão negativa de citoqueratina 10 (K10), com expressão apenas focal na camada córnea (x200). (C) Expressão de citoqueratina 14 (K14) em toda a epiderme (x200) (técnica de estreptoavidina-biotina-peroxidase). 


\subsubsection{Citoqueratinas 4 e 16}

As citoqueratinas 4 e 16 são expressas nas verrugas planas e na EV.

Todos os casos de VP e EV apresentaram expressão de K4 (Figuras 14 A e B). Nas verrugas planas $64,28 \%$ dos casos expressaram essa citoqueratina no citoplasma de queratinócitos das camadas basal e espinhosa da epiderme e $35,71 \%$ dos casos, apenas na camada espinhosa. $\mathrm{Na} \mathrm{EV}, 73,33 \%$ dos casos expressaram K4 nas camadas basal e espinhosa da epiderme e, 26,66\% apenas na camada espinhosa. A Tabela 11 demonstra as freqüências de expressão de K4 nos dois grupos.

Tabela 11 - Padrão de expressão da citoqueratina 4 nas verrugas planas e nas lesões de epidermodisplasia verruciforme.

\begin{tabular}{ccccc}
\hline \hline & \multicolumn{2}{c}{ Basal e espinhosa } & \multicolumn{2}{c}{ Espinhosa } \\
\cline { 2 - 5 } & $\mathbf{n}$ & $\%$ & $\mathbf{n}$ & $\%$ \\
\hline \hline VP & $9 / 14$ & 64,28 & $5 / 14$ & 35,71 \\
EV & $11 / 15$ & 73,33 & $4 / 15$ & 26,66 \\
\hline \hline
\end{tabular}

VP: verruga plana; EV: epidermodisplasia verruciforme (teste exato de Fisher $\mathrm{p}>0,05$ ). 

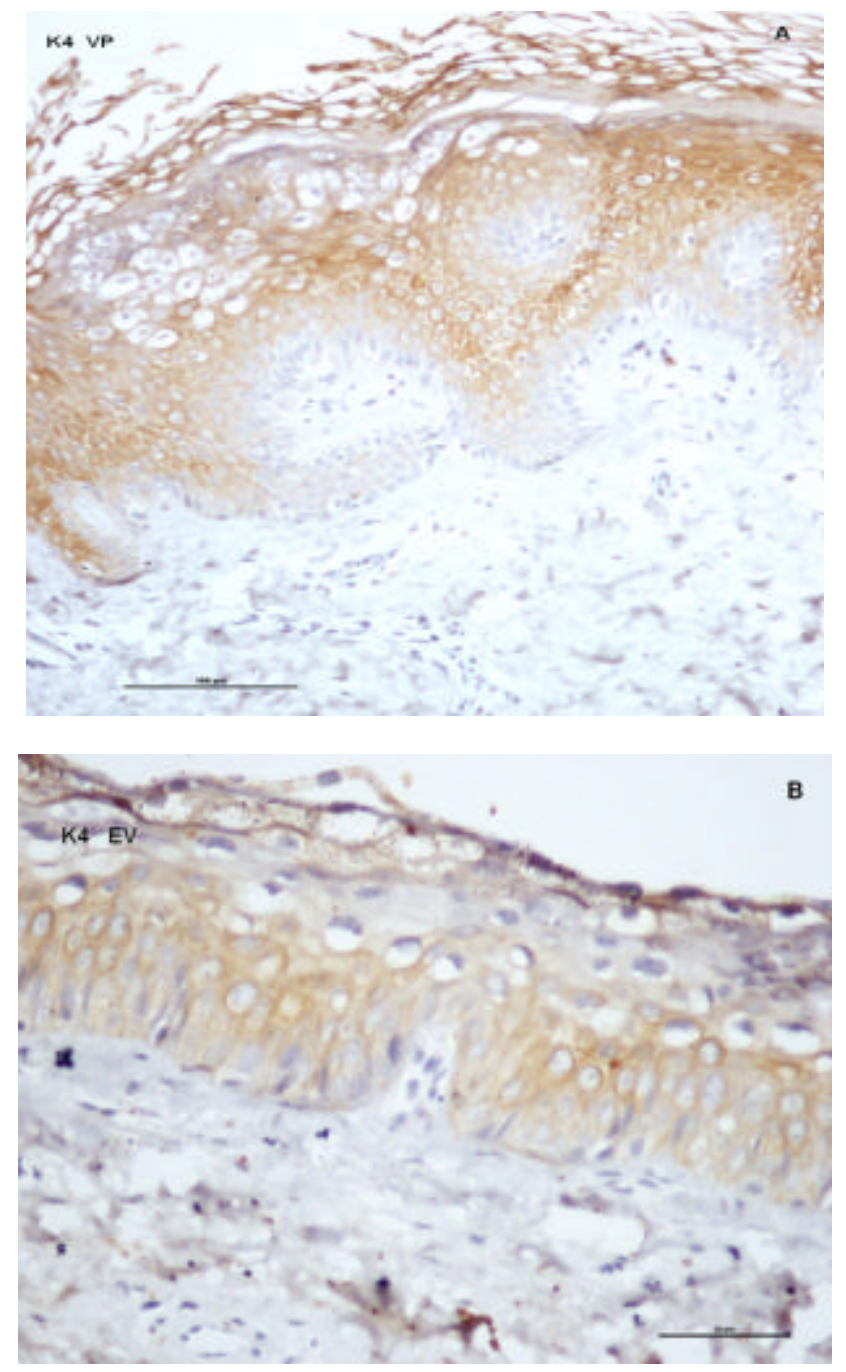

Figura 14 - Expressão difusa de citoqueratina $4(\mathrm{~K} 4)$ na (A) verruga plana $(V P)$ e na (B) epidermodisplasia verruciforme (EV) (x200) (técnica de estreptoavidina-biotina-peroxidase). 
A citoqueratina 16, habitualmente ausente na epiderme normal, foi detectada em $71,42 \%$ dos casos de verrugas planas (Figura $15 \mathrm{~A}$ ) e em $80 \%$ dos casos de EV (Figura 15 B). No grupo de verrugas planas a expressão de K16 na camada espinhosa da epiderme apresentou um padrão difuso, enquanto na EV observourse expressão focal dessa citoqueratina. A Tabela 12 apresenta a freqüência dos padrões de expressão de K16 em ambos os grupos.
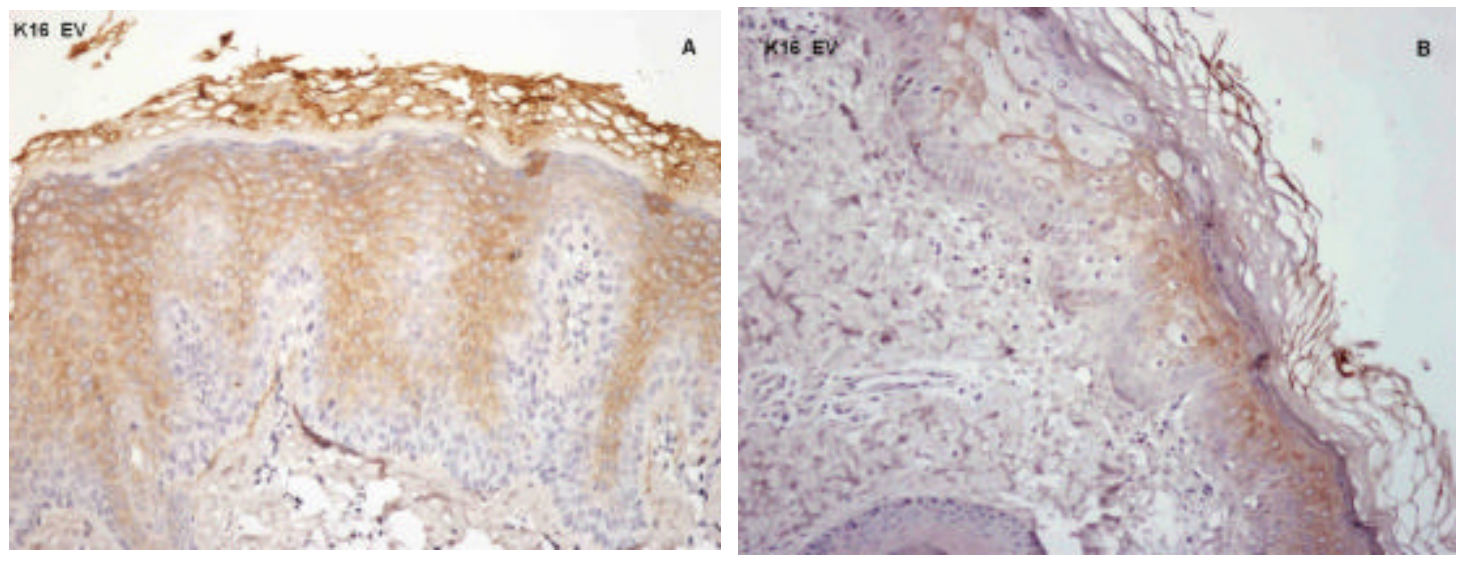

Figura 15 - (A) Expressão difusa de citoqueratina 16 (K16) na camada espinhosa na verruga plana (VP) (x100). (B) Expressão focal de citoqueratina 16 (K16) na camada espinhosa na epidermodisplasia verruciforme (EV) (x100). (técnica de estreptoavidina-biotina-peroxidase). 
Tabela 12 - Padrão de expressão da citoqueratina 16 nas verrugas planas e nas lesões de epidermodisplasia verruciforme.

\begin{tabular}{ccccccc}
\hline \hline & \multicolumn{2}{c}{ Espinhosa difusa } & \multicolumn{2}{c}{ Espinhosa focal } & \multicolumn{2}{c}{ Negativa } \\
\cline { 2 - 7 } & $\mathbf{n}$ & $\%$ & $\mathbf{n}$ & $\%$ & $\mathbf{n}$ & $\%$ \\
\hline \hline VP & $10 / 14$ & 71,42 & 0 & 0 & $4 / 14$ & 28,57 \\
EV & $1 / 15$ & 6,66 & $11 / 15$ & 73,33 & $3 / 15$ & 20,00 \\
\hline \hline
\end{tabular}

VP: verruga plana; EV: epidermodisplasia verruciforme (teste do Qui-quadrado $p<0,0001$ ).

\subsubsection{Expressão de involucrina, filagrina e e-caderina nas verrugas planas e na EV}

\subsubsection{Involucrina}

A expressão de involucrina ocorreu precocemente nas verrugas planas e na $E V$.

Observou-se expressão de involucrina nos queratinócitos das camadas espinhosa inferior até a granulosa em $42,85 \%$ dos casos de verrugas planas (Figura 16 B) e em $66,66 \%$ dos casos de EV (Figura 16 C). Expressão focal de involucrina nos queratinócitos da camada basal da 
epiderme foi observada em $33,33 \%$ dos casos de verrugas planas e em $10 \%$ dos casos de EV (Tabela 13). A epiderme normal perilesional, quando presente, apresentou o padrão habitual de expressão de involucrina.

Tabela 13 - Padrão de expressão da involucrina nas verrugas planas e nas lesões de epidermodisplasia verruciforme.

\begin{tabular}{ccccc}
\hline \hline & \multicolumn{2}{c}{$\begin{array}{c}\text { A partir da basal ou espinhosa } \\
\text { inferior }\end{array}$} & A partir da espinhosa superior \\
\cline { 2 - 5 } & $\mathbf{n}$ & $\%$ & $\mathbf{n}$ & $\%$ \\
\hline \hline VP & $6 / 14$ & 42,85 & $8 / 14$ & 57,14 \\
EV & $10 / 15$ & 66,66 & $5 / 15$ & 33,33 \\
\hline \hline
\end{tabular}

VP: verruga plana; EV: epidermodisplasia verruciforme (teste exato de Fisher $p>0,05$ ) 

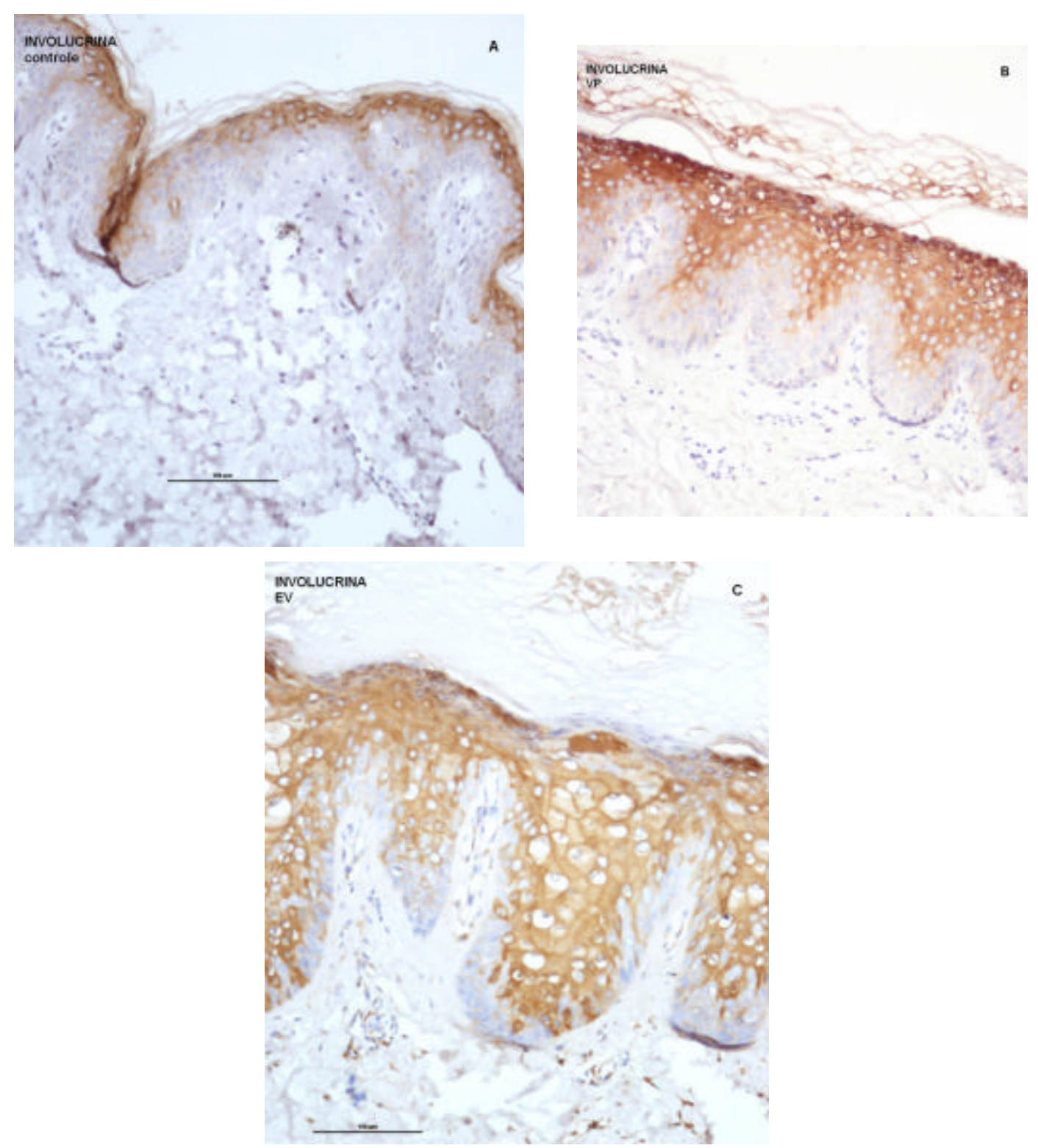

Figura 16 - Expressão de involucrina na epiderme (A) normal-controle; Epiderme normal controle; (B) verruga plana e (C) epidermodisplasia verruciforme (técnica de estreptoavidinabiotina-peroxidase).

O Anexo 4 apresenta os resultados comparativos das citoqueratinas e involucrina, descritos acima, nos grupos de verruga plana e EV. 


\subsubsection{Filagrina}

A expressão de filagrina não foi alterada nas verrugas planas e na $E V$.

Em ambos os grupos a expressão de filagrina apresentou o mesmo padrão da pele normal (grupo controle, Figura 17 A). Houve expressão de filagrina nos queratinócitos da camada granulosa e também nas áreas de coilocitose (Figuras 17 B e C). Nas lesões de EV a expressão de filagrina ocorreu apenas nas camadas mais superficiais dos focos de coilocitose (mais próximas à camada granulosa), e foi ausente nos focos coilocitóticos mais profundos. 


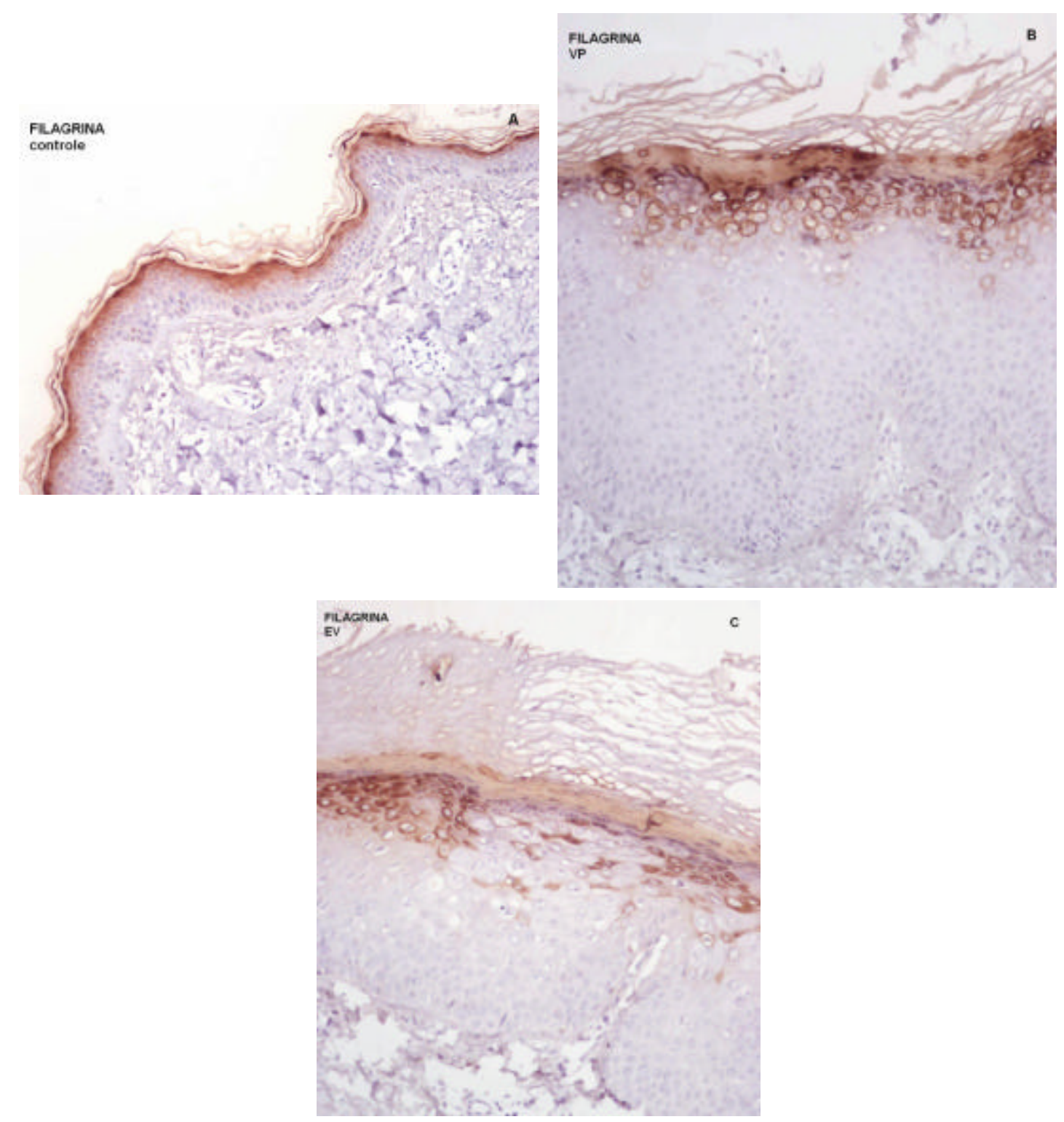

Figura 17 - Expressão de filagrina na (A) epiderme normal - controle, (B) verruga plana e (C) epidermodisplasia verruciforme (técnica de estreptoavidina-biotina-peroxidase). 


\subsubsection{E-caderina}

A expressão de e-caderina foi diminuída nas células coilocitóticas superficiais na $E V$.

Nas lesões de verruga plana e EV observou-se expressão de ecaderina, com o padrão intercelular nos queratinócitos sem alteração citopática evidente. Nas áreas de coilocitose das verrugas planas houve ausência de expressão de e-caderina (Figura 18 B). Na EV os queratinócitos alterados das camadas mais profundas da epiderme apresentaram expressão membranosa de e-caderina. Entretanto, observou-se ausência de expressão dessa molécula de adesão nas camadas epidérmicas mais superficias das lesões desse grupo (Figura 18 C). A Tabela 14 demonstra os dados quanto à expressão de e-caderina na verruga plana e EV.

Tabela 14 - Expressão epidérmica de ecaderina nas verrugas planas e nas lesões de epidermodisplasia verruciforme.

\begin{tabular}{ccccc}
\hline \hline & \multicolumn{2}{c}{ Camadas basal e espinhosa } & \multicolumn{2}{c}{ Áreas de coilocitose $^{*}$} \\
\cline { 2 - 5 } & $\mathbf{n}$ & $\%$ & $\mathbf{n}$ & $\%$ \\
\hline \hline VP & $14 / 14$ & 100 & $4 / 14$ & 28,57 \\
EV & $15 / 15$ & 100 & $12 / 15$ & 80,00 \\
\hline \hline
\end{tabular}

VP: verruga plana; EV: epidermodisplasia verruciforme;

${ }^{*}$ teste exato de Fisher $p<0.05$. 

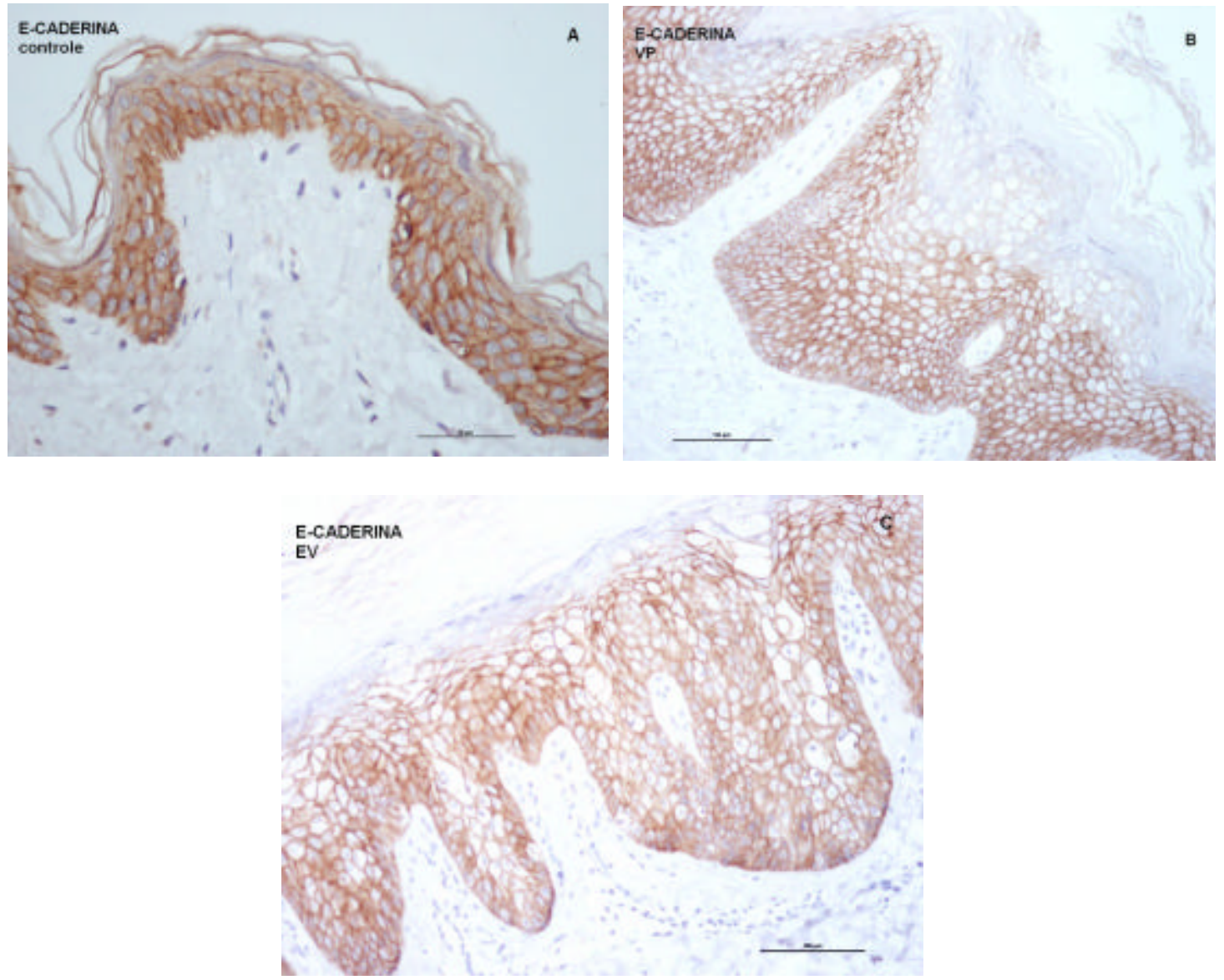

Figura 18 - Expressão de e-caderina na (A) epiderme normal-controle, (B) verruga plana e (C) epidermodisplasia verruciforme (técnica de estreptoavidina-biotina-peroxidase). 
Discussão 


\section{DISCUSSÃO}

A epidermodisplasia verruciforme (EV) é uma genodermatose rara, caracterizada por susceptibilidade à infecção por um grupo de vírus do papiloma humano (Majewski e Jablonska, 1997a; 1998). Os vírus associados à EV são designados EV-HPV (Orth et al., 1978; 1979).

Apesar da EV ser uma doença rara, pudemos analisar lesões do tipo de verrugas planas associadas à EV de 15 doentes, com diagnóstico clínico comprovado da doença, e acompanhados na Divisão de Clínica Dermatológica do Hospital das Clínicas da Universidade de São Paulo.

As lesões de verrugas planas (VP) encontradas na população em geral apresentam prevalência maior do que a EV mas mesmo assim, sua prevalência geral foi de apenas 0,54\% em um estudo com 50237 pacientes avaliados consecutivamente em um serviço de dermatologia (Kyriakis et al., 2006). Além disso, como o diagnóstico de VP na população em geral na grande maioria das vezes é apenas clínico, muitas dessas lesões não são submetidas à biopsia para sua comprovação antes do tratamento. 
Apesar dessas limitações conseguimos recuperar 14 casos de VP em indivíduos sem evidências de alterações da imunidade para inclusão no estudo.

Não observamos diferenças entre os grupos de EV e VP em relação ao sexo (seis homens e oito mulheres no grupo de VP; sete homens e oito mulheres no grupo de EV), ou em relação à idade (idade média 32,6 anos no grupo de VP e 33,3 anos no grupo de EV).

Todos os espécimes estudados apresentaram alterações histológicas características. No grupo de VP foi observada hiperqueratose, acantose, com presença de células coilocitóticas nas camadas espinhosa superior e granulosa da epiderme, acompanhadas de leve papilomatose. Essas alterações são concordantes com as descritas na literatura (Jablonska e Majewski 1994; 1997a).

Embora não tenhamos realizado a identificação dos HPV nos espécimes avaliados, nos casos de EV todos apresentavam alterações histopatológicas características do efeito citopático viral desencadeado pelos EV-HPV (Jablonska e Majewski, 1994, 1997a; Nuovo e Ishag, 2000). Além da acantose, de leve a moderada, havia hiperqueratose em cesta, e queratinócitos volumosos, com citoplasma abundante, de tonalidade cinzaazulada, com halos perinucleares e grânulos de queratohialina irregulares. Os queratinócitos alterados eram observados já na camada espinhosa inferior. 
Em nenhum dos casos de EV observamos os achados histopatológicos de VP causadas pelo HPV 3 e/ou 10, como o aspecto em “olhos de pássaro" (Jablonska e Majewski, 1994).

Avaliamos, pela técnica imuno-histoquímica, o perfil de expressão epidérmica de citoqueratinas, involucrina, filagrina e e-caderina na VP e nas lesões do tipo verruga plana de pacientes com EV.

A imuno-histoquímica é uma técnica essencialmente qualitativa, embora aplicações quantitativas ou semi-quantitativas possam ser realizadas para determinar a intensidade em que o antígeno se encontra na amostra. Seu objetivo básico é a localização topográfica dos antígenos estudos nas células ou tecidos (Alves e Roman, 2005).

O método do estudo, através da exposição dos sítios antigênicos com solução tampão e calor com o uso de forno de microondas, revelourse adequado para a detecção das citoqueratinas e dos demais antígenos estudados pelas técnicas imuno-histoquímicas (Alves e Roman, 2005).

Alterações na expressão das citoqueratinas em lesões tegumentares de natureza viral, particularmente em relação ao condiloma acuminado, já têm sido descritas (Mullink et al., 1991; Staquet et al., 1981; McCance et al., 1988; Woodworth et al., 1990; Nogueira-Castañon et al., 2004). Entretanto, não encontramos relatos sobre o perfil de expressão epidérmica das citoqueratinas, involucrina, filagrina e e-caderina, nas verrugas planas associadas à EV. 


\subsection{Citoqueratinas}

As citoqueratinas são filamentos intermediários das células epiteliais, que caracterizam o tipo e a diferenciação celular. Os queratinócitos da camada basal expressam $\mathrm{K} 5$ e $\mathrm{K} 14$, e os das camadas suprabasais $\mathrm{K} 1$ e K10 (Moll et al., 1982). K16 e K4 não são expressas na epiderme normal (Smack et al., 1994; Almeida Jr, 2004)

\subsubsection{A expressão das citoqueratinas 1, 10 e 14 está alterada, especialmente nas lesões de epidermodisplasia verruciforme}

Ambos os grupos de verrugas planas estudadas (associados ou não à EV) apresentaram retardo na expressão das K1 e 10, com sua expressão apenas nas camadas mais superficiais da epiderme. Estas citoqueratinas

foram aparentemente substituídas pela $K 14$, que foi expressa desde a camada basal até a camada espinhosa superior. Estas alterações foram mais evidentes nos casos de EV.

Em $84,61 \%$ dos casos de VP foi observado o padrão habitual de expressão de K1 (camada espinhosa), sendo que em 15,38\% dos casos a positividade ocorreu apenas na camada espinhosa superior. 
Na EV a expressão habitual de K1 ocorreu em apenas $26,66 \%$ dos casos, com expressão tardia em $15,38 \%$ dos casos, e expressão apenas focal em $20 \%$ dos casos.

A expressão de $\mathrm{K} 1$ na pele normal ocorre apenas nos queratinócitos em diferenciação terminal (Stoler et al., 1988).

Com relação à expressão de citoqueratinas nas VP encontramos o trabalho de Moll et al. (1984) que, através de técnica de eletroforese em gel, demonstraram nas lesões de VP da população em geral uma grande quantidade de $\mathrm{K} 1$, que excedia a das outras citoqueratinas, como habitualmente observado na pele normal. Os autores verificaram pequenas quantidades das demais citoqueratinas (2, 4, 5, 6, 10, 15, 16 e 17). Entretanto, foi descrita na VP uma menor quantidade de $K 1$, quando comparada à epiderme normal (Staquet et al., 1981).

A epiderme das verrugas vulgares apresenta pequenas quantidades de $\mathrm{K} 1,10,11$ e maior quantidade de citoqueratinas relacionadas à proliferação celular e processos hiperproliferativos como as K 5, 14, 6 e 16 (Moll et al., 1984).

Expressão diminuída ou retardada de $\mathrm{K} 1$ e $\mathrm{K} 10$ foi observada no condiloma acuminado genital (Mullink et al., 1991; Nogueira-Castañon et al., 2004).

Experimentos in vitro demonstraram que células cervicais uterinas e de prepúcio, imortalizadas pelos HPV oncogênicos 16, 18, 31 e 33, apresentam níveis diminuídos de RNA para K1 (Woodworth et al., 1990). 
As alterações da expressão de K10 foram ainda mais acentuadas nas lesões do grupo de EV. Somente $26,66 \%$ das lesões de EV apresentaram expressão habitual de K10 nas camadas suprabasais da epiderme. Em 40\% dos casos de EV a expressão de K10 ocorreu apenas na camada espinhosa superior, e em $33,33 \%$ dos casos a expressão foi negativa. No grupo de lesões de VP a expressão habitual de K10 nas camadas suprabasais na epiderme foi observada em $92,30 \%$ dos casos.

Ensaios experimentais com a transdução dos genes E6 e E7 de EVHPV (tipos 5, 12, 15, 17, 20 e 38) demonstraram alteração do crescimento e diferenciação de queratinócitos em culturas organotípicas com expressão de K10 apenas nas camadas suprabasais mais superficiais (Boxmann et al., 2001). Esse trabalho embasa as nossas observações nas lesões de EV, onde as alterações do padrão de expressão de K10 foram evidenciadas por técnica imuno-histoquímica. Podemos correlacionar a expressão alterada de K10 com a ação dos EV-HPV no processo de queratinização da epiderme que os alberga.

A perda de expressão de $\mathrm{K} 10$ foi também descrita em tumores malignos. Nanyi et al. (1989) analisando o perfil de K10 em carcinomas de vulva evidenciaram risco aumentado de recorrência das lesões que não expressavam K10. Os autores, entretanto, não referem se essas neoplasias estudadas eram relacionadas à infecção pelo HPV.

Todas as lesões de nosso estudo apresentaram positividade para K14 nas camadas basal e parabasal, como o observado na epiderme normal. 
Entretanto, expressão de K14 foi observada também nas camadas suprabasais da epiderme em $42,85 \%$ dos casos de VP e em $100 \%$ dos casos de EV.

É interessante ressaltar que nas oito lesões de EV com expressão retardada de $\mathrm{K} 1$, assim como nos casos com ausência de expressão de $\mathrm{K} 10$, essas citoqueratinas foram substituídas pela $\mathrm{K} 14$. A pele normal adjacente, quando presente, apresentou o padrão normal de expressão de $\mathrm{K} 1 / 10 / 14$.

Embora a K14 seja expressa apenas na camada basal da epiderme normal, a presença de K14 mRNA ocorre também nas camadas suprabasais (Tyner e Fuchs, 1986).

A expressão suprabasal de $\mathrm{K} 14$ substituindo $\mathrm{K} 1$ e $\mathrm{K} 10$ é relatada na epiderme de processos regenerativos (Kallioinem et al., 1995; Kurokawa et al., 2006), na psoríase (Stoler et al., 1988), nas queratoses actínicas (Smoller et al., 1990), e nas doenças infecto-parasitárias associadas à hiperplasia epidérmica como a paracoccidioidomicose, cromomicose, leishmaniose e condiloma acuminado (Nogueira-Castañon et al., 2004). Nas lesões de condiloma acuminado apesar de ocorrer expressão suprabasal de $\mathrm{K} 14$, a sua expressão também permanece inalterada nas camadas basais. Segundo esses autores, as alterações da diferenciação epitelial induzidas pelo HPV afetariam principalmente o compartimento suprabasal da epideme (Nogueira-Castañon et al., 2004). 
Experimentos in vitro demonstram que o HPV 16 (oncogênico) altera a diferenciação epidérmica. Células contendo DNA do HPV 16, embora sejam capazes de se estratificar, apresentam expressão reduzida ou em mosaico de $\mathrm{K} 1$ e K16, e expressão de $\mathrm{K} 14$ em todas as camadas da epiderme formada em situações de cultivo celular (Mc Cance et al., 1988).

Alterações no perfil de citoqueratinas ocorrem na pele perilesional de carcinomas basocelulares e espinocelulares (Thomas et al., 1984) e em lesões pré-malignas como as queratoses actínicas (Smoller et al., 1990). Na epiderme adjacente aos tumores a expressão de citoqueratinas basais é observada também em toda a espessura da epiderme e substitui a expressão das citoqueratinas suprabasais (Thomas et al., 1984). Essa observação é semelhante ao que verificamos nas lesões de EV. Essa alteração de expressão de citoqueratinas relacionadas à diferenciação, que são substituídas por K14 poderia representar uma característica de potencial oncogênico das lesões de EV.

\subsubsection{As citoqueratinas 4 e 16 são expressas nas verrugas planas e na epidermodisplasia verruciforme}

Observamos expressão de K16 em $71,42 \%$ dos casos de VP e em 80\% das lesões de EV. Nas lesões de VP a expressão de K16 apresentou- 
se com padrão difuso na camada espinhosa da epiderme. Entretanto, na EV assumiu um padrão focal.

A expressão anormal de $\mathrm{K} 16$ reflete uma diferenciação anormal dos queratinócitos em ambas as lesões induzidas pelo HPV. A K16 (coexpressa com a K6) não é encontrada na epiderme normal, estando presente apenas na epiderme das regiões palmares e plantares e na bainha externa dos folículos pilosos (Moll et al., 1982; Moll et al., 1984). Embora a K6 não se expresse na epiderme normal, o seu mRNA pode ser detectado em todas as camadas da epiderme. Desse modo, a expressão de K6 ocorre rapidamente nos estados hiperproliferativos ou de transformação maligna dos epitélios pluriestratificados escamosos (Tyner e Fuchs, 1986).

Embora K6/16 estejam freqüentemente associadas com estados hiperproliferativos, essas citoqueratinas são produzidas apenas nas células em diferenciação, que não sofrem mais divisão celular. Sua expressão pode ser suprimida com uso de ácido retinóico, sem uma diminuição correspondente na proliferação epitelial. Desse modo, a expressão de K6/16 representaria mais uma conseqüência do que a causa da proliferação epitelial aumentada (Kopan e Fuchs, 1989). Contrariamente, de Mare et al. (1990) evidenciaram, por ensaios de indução de trauma padronizado, que a expressão de K16 nas camadas suprabasais precede a proliferação epidérmica, sugerindo um papel do compartimento suprabasal na indução do crescimento epidérmico. Esses mesmos autores também observaram que a expressão de K10 diminui, aproximadamente um dia após o início da 
expressão de K16, o que sugere que os processos não são dependentes um do outro.

Nos doentes com psoríase a expressão de K6/16 ocorre também na pele clinicamente normal, o que refletiria um estado pré-clínico de hiperproliferação epidérmica. Esses eventos estariam envolvidos no aparecimento de lesões em áreas de trauma (fenômeno de Köebner) na doença (Thewes et al., 1991).

A K16 é observada na epiderme ainda não hiperplásica dos processos infecciosos da pele como a paracoccidioidomicose, cromomicose e leishmaniose. A presença de K16 nos queratinócitos, antecedendo a hiperplasia epidérmica, indicaria que sua expressão não seria conseqüência da hiperproliferação, mas que os mecanismos que culminariam na hiperproliferação epidérmica já teriam sido desencadeados ou já estariam estabelecidos (Nogueira-Castañon et al., 2004). Esses autores também demonstraram positividade para K16 em lesões de condiloma acuminado.

Expressão de K6/16 é relatada em processos neoplásicos cutâneos como o carcinoma espinocelular e queratoacantoma (Moll et al., 1984).

A expressão subrabasal de K6/16 substituindo K1/10 é observada em situações associadas com o aumento da proliferação epidérmica, como a epiderme regenerativa (Kallioinem et al., 1995; Kurokawa et al., 2006), psoríase (Stoler et al., 1988; Leigh et al., 1995), hiperplasias 
pseudocarciomatosas e outros estados proliferativos epidérmicos (Moll et al., 1984; Stoler et al., 1988; Kurokawa et al., 2006).

Observamos, particularmente nas lesões de EV, a substituição de expressão de K1/10 pela expressão de K14. Além disso, esta alteração associou-se à expressão de K16. Nos processos de regeneração ou proliferação aumentada da epiderme foi verificado que K6/16 substituem a expressão de $\mathrm{K} 1 / 10$ nas camadas suprabasais. Essa alteração é considerada um defeito, ou inibição, da diferenciação terminal dos queratinócitos. Supõe-se que essas mudanças representem um reflexo da imaturidade e falta de diferenciação da epiderme durante os estados anormais, uma vez que muitas vezes se observa também expressão aberrante de K13 e 18, que são queratinas expressas na epiderme fetal (Kallioinem et al., 1995).

Demonstramos expressão aberrante de K4 nas camadas basais e/ou suprabasais da epiderme em todos os casos de verrugas planas relacionadas ou não com a EV.

Moll et al. (1984), através de análise por eletroforese, demonstraram pequenas quantidades de K4 em VP não relacionadas à EV. A presença de K4 em condilomas acuminados causados pelo HPV 6 e 11 também já foi relatada na literatura (Mullink et al., 1991).

A citoqueratina 4 está presente nos epitélios não queratinizados (esôfago, língua, mucosa oral, faringe, laringe, epiglote, exocérvix uterina, 
vagina, glândulas sebáceas e glândulas axilares apócrinas) e é expressa na epiderme fetal (Moll et al., 1982; Smack et al., 1994; Van Muijen et al., 1987; Leube et al., 1988). Naqueles epitélios não queratinizados, embora a K4 seja habitualmente expressa nas camadas suprabasais, os genes que a codificam já estão presentes na camada basal (Leube et al., 1988).

Expressão de K4 é observada em células de carcinoma espinocelular pouco diferenciado e nas suas metástases linfonodais. Essa expressão aberrante é considerada como decorrente da imaturidade das células neoplásicas. A expressão de citoqueratinas específicas de epitélios estratificados não queratinizados no carcinoma espinocelular é considerada um possível marcador para o potencial metastático desses tumores (Watanabe et al.,1995).

A expressão aberrante de $K 4$, nos casos de VP e na $E V$, sugere que as alterações na diferenciação epidérmica induzidas pelo HPV poderiam levar a uma imaturidade dos queratinócitos, como o observado no carcinoma espinocelular. 


\subsubsection{As alterações das citoqueratinas encontradas nas verrugas planas e epidermodisplasia verruciforme não se correlacionam com a exposição solar}

As lesões estudadas foram obtidas de áreas fotoexpostas $(78,57 \%$ das lesões de VP e $40 \%$ das lesões de EV) e não-fotoexpostas (14,28\% dos casos de VP e 53,33\% dos casos de EV). Nenhuma lesão era localizada nas regiões palmo-plantares. Nesses locais o perfil de expressão de citoqueratinas é diferente da epiderme das outras áreas corpóreas, sendo expressas as citoqueratinas $\mathrm{K} 1,2,5,6,9,10,11,14$ e 16 (Moll et al., 1982).

A radiação UVB (290-320nm) pode induzir a transcrição do gene da K19, e em menor grau de K5, 14 e 6. A radiação UVA induz a transcrição de K17. O discreto aumento de K5, 14 e 6 relaciona-se ao estímulo proliferativo transitório da epiderme induzido pela radiação UVB (Bernerd et al., 2001).

As alterações do processo de queratinização observados nas lesões de VP e EV não guardaram relação com a fotoexposição, pois não observamos diferenças no padrão de expressão dos marcadores estudados entre as lesões localizadas em áreas expostas e não fotoexpostas. 


\subsection{Involucrina}

\subsubsection{A expressão de involucrina ocorreu mais próxima à camada basal nas verrugas planas e na epidermodisplasia verruciforme}

A expressão precoce de involucrina, nas células das camadas basal e espinhosa inferior da epiderme foi observada tanto nas lesões de VP como nas lesões do tipo verruga plana da EV.

A expressão de involucrina ocorre no envelope corneificado dos queratinócitos, e é considerada um marcador de diferenciação terminal da epiderme (Smack et al., 1994; Watt, 1983; Ishida-Yamamoto et al., 1997). Na epiderme normal a sua expressão ocorre a partir da camada espinhosa superior (Watt, 1983; Ishida-Yamamoto et al., 1997).

A expressão precoce de involucrina foi descrita em células de epitélio cervical uterino e prepúcio imortalizadas por HPV oncogênico. Entretanto, nas lesões de HPV com displasia epitelial acentuada, a expressão de involucrina mostra-se ausente ou com um padrão em mosaico (Woodworth et al., 1990).

Na psoríase, à semelhança do que observamos na VP e EV, ocorre expressão precoce de involucrina, que já é expressa por vezes nas camadas parabasal e basal da epiderme (Bernard et al., 1986). Expressão de 
involucrina a partir da porção medial da camada espinhosa também é encontrada em queratoses actínicas (Smoller et al.,1990).

Expressão precoce de SPRR2 (pequenas proteínas ricas em prolina), que são precursoras do envelope corneificado, foi demonstrada em culturas de queratinócitos que albergam EV-HPV (tipos 5, $12,15,17,20$ e 38) e expressam oncoproteínas E6 e E7. Essas observações indicariam o processo de diferenciação epidérmica terminal precoce, induzida pelos EVHPV. A transdução dos genes E6 e E7 dos HPV tipo 5 e 12 causam retardo e alterações na diferenciação dos queratinócitos de modo mais intenso que as alterações induzidas por outros tipos de EV estudados. Os HPV de tipo 15 e 17 apresentam maior capacidade de promover proliferação de queratinócitos basais (Boxmann et al., 2001).

Demonstramos através da técnica imuno-histoquímica a expressão de involucrina nas camadas mais profundas da epiderme, sugerindo processo de diferenciação terminal precoce da epiderme alterada. Entretanto, essa alteração não ocorreu somente na $E V$, sendo também observada nas verrugas planas da população em geral. 


\subsection{Filagrina e e-caderina}

\subsubsection{A expressão de filagrina e e-caderina não é marcadamente alterada nas verrugas planas e na epidermodisplasia verruciforme}

Em ambos os grupos de lesões de VP e EV, o padrão de expressão de filagrina não diferiu daquele da epiderme normal (controles). A filagrina expressou-se nos queratinócitos da camada granulosa e também nos focos de coilocitose. Nas lesões de EV a expressão de filagrina ocorreu apenas nas células coilocitóticas mais superficiais (da camada granulosa, local de expressão normal de filagrina), estando ausente nos focos coilocitóticos mais profundos. Esse padrão de expressão de filagrina indicaria que a mesma estaria mais relacionada com topografia e diferenciação celular do que com as alterações celulares secundárias à coilocitose.

A filagrina é o principal componente dos grânulos de querato-hialina, e também é marcador da fase terminal do processo de queratinização epidérmica (Dale e Ling, 1979; Fleckman et al., 1985, Steinert e Marekov, 1995).

Ao contrário de nossas observações nas lesões cutâneas de VP e EV, Merrick et al. (1992) demonstraram ausência de expressão de filagrina em cultura de queratinócitos imortalizados pelos HPV 16 e 18, nas linhagens 
celulares que não apresentaram diferenciação terminal. Comentam que a perda de expressão de filagrina seria uma característica dos epitélios indiferenciados.

Por outro lado, Viac et al. (1989) descreveram aumento de expressão de pró-filagrina/filagrina nas camadas epidérmicas superiores de verrugas vulgares e condilomas acuminados. Nos papilomas de laringe a expressão de filagrina ocorria na camada suprabasal e era mais intensa nas camadas mais superficiais do epitélio laríngeo. Nas neoplasias intraepiteliais cervicais, a expressão de filagrina ocorreu, em alguns casos, apenas nas camadas mais superficiais epiteliais, e em outros foi negativa. Segundo os autores, esses dados sugerem uma intensa expressão de pró-filagrina / filagrina nas lesões benignas onde ocorre replicação viral e expressão pequena ou ausente em lesões pré-malignas e malignas.

Guérin-Reverchon et al. (1990) evidenciaram diminuição na expressão de pró-filagrina/filagrina em casos de Doença de Bowen extragenital e papulose bowenóide genital, associados ou não a HPV.

Em nosso estudo embora tenham sido avaliadas lesões benignas relacionadas ao HPV, não foi observada alteração na expressão de filagrina comparada aos controles.

Observamos expressão intercelular de ecaderina nos queratinócitos basais e suprabasais da epiderme em ambos os grupos. A expressão de ecaderina foi ausente nos focos de coilocitose em $71,43 \%$ das lesões de VP 
não associadas à EV. Entretanto $80 \%$ dos casos de verrugas planas da EV apresentaram expressão de e-caderina nas células coilocitóticas, mas apenas nas camadas epidérmicas mais inferiores. Este aspecto poderia se relacionar com o fato das células coilocitóticas na EV já estarem presentes nas camadas mais profundas da epiderme, enquanto nas verrugas planas não-EV a coilocitose está presente nas camadas mais superficiais, onde a expressão de e-caderina é habitualmente diminuída.

As e-caderinas são glicoproteínas transmembrânicas importantes na adesão intercelular, na estratificação e diferenciação epidérmica (Wheelock e Jensen, 1992; Hines et al., 1999). Alterações no complexo caderinacatenina foram observadas em tumores de diversos tecidos e foram correlacionadas com características clínicas e patológicas, como desdiferenciação, crescimento infiltrativo, metástases linfonodais e pior prognóstico (Tada et al., 1996; Okegawa et al., 2002; Lyakhovitsky et al., 2004).

Os HPV não são vírus líticos. Após a síntese de DNA viral o genoma viral é incorporado em uma partícula (cápside) formada pelas proteínas L1 e L2 sendo liberado para o meio ambiente conforme o epitélio sofre seu processo de maturação e descamação (Androphy, 1994).

A diminuição de expressão de e-caderina nas camadas superiores de coilocitose na EV, e nas células coilocitóticas nas VP poderia auxiliar na 
perda de adesão intercelular dos queratinócitos superficiais, facilitando a liberação viral.

Papadavid et al. (2002) em estudo da expressão de ecaderina em lesões pré-malignas e malignas (tumores cutâneos não-melanoma) evidenciaram que a probabilidade de expressão anormal de e-caderina aumenta conforme a progressão para malignidade. Neste mesmo estudo analisaram 20 verrugas virais de indivíduos transplantados renais, que apresentaram expressão normal de e-caderina.

Os genes E6 e E7 do HPV 16 inibem a expressão de e-caderina, e esta alteração se correlaciona com um fenótipo invasivo dos queratinócitos e com a depleção das células de Langerhans na epiderme das lesões (Wilding et al., 1996; Mathews et al., 2003). Poderíamos também interpretar a menor expressão de e-caderina nas lesões de EV, como relacionada ao potencial oncogênico cutâneo dessas lesões.

Na epiderme normal as interações adesivas da e-caderina mantém a baixa expressão de pró-filagrina (precursor da filagrina). Na camada granulosa da epiderme, onde a expressão de e-caderina já não se faz presente, a filagrina é intensamente expressa. A inibição da e-caderina aumenta drasticamente os níveis de pró-filagrina (Hines et al., 1999). Nas nossas observações das lesões de VP e de EV a expressão de e-caderina e filagrina não sofreram alterações concomitantes significativas. 


\subsection{Considerações finais}

O conjunto dos resultados obtidos quanto à expressão de citoqueratinas, involucrina, filagrina e e-caderina nas lesões de VP e de EV indicam que a infecção pelo HPV altera o processo de queratinização e de diferenciação celular dos queratinócitos em ambos os grupos estudados. Essas alterações são representadas por uma substituição de citoqueratinas relacionadas á diferenciação celular $(\mathrm{K} 1 / 10)$ e por manutenção da expressão de citoqueratina de células imaturas e proliferantes (K14). Há expressão aberrante de K16, citoqueratina dos estados hiperproliferativos, e de K4, que é observada na epiderme fetal. O vírus também interfere na formação do envelope celular, induzindo expressão precoce de involucrina. Essas alterações observadas, entretanto, são mais acentuadas nas verrugas planas relacionadas à $\mathrm{EV}$.

A expressão suprabasal de $K 14$, e a expressão mais precoce de involucrina e filagrina indicariam um fenótipo de queratinócitos "ativados" (regenerativos/ proliferativos), sendo encontrado por exemplo na epiderme em regeneração, na epidermólise bolhosa distrófica recessiva e em queratoses actínicas (Smoller et al., 1990). Esse fenótipo é característico em condições que predispõem ao desenvolvimento de carcinomas espinocelulares (Smoller et al., 1990). 
O fato das alterações encontradas serem mais acentuadas nas lesões de verrugas planas associadas à EV poderia se relacionar com o maior potencial oncogênico da doença. 
Conclusões 


\section{CONCLUSÕES}

A avaliação da expressão de citoqueratinas, involucrina, filagrina e ecaderina nas lesões de verruga plana e de verrugas planas da epidermodisplasia verruciforme (EV) permitiram concluir que:

- A infecção pelo HPV altera o processo de queratinização da epiderme nas verrugas planas e nas verrugas planas associadas à EV. A queratinização alterada é evidenciada por:

- Diminuição da expressão suprabasal de citoqueratinas 1 e 10, que são aparentemente substituídas pela expressão suprabasal de citoqueratina 14 .

- Expressão aberrante de citoqueratinas 4 e 16, usualmente ausentes na epiderme normal.

- Ocorre formação precoce do envelope celular evidenciado pela expressão de involucrina nas camadas mais inferiores da epiderme, tanto nas lesões de verruga plana como na verruga plana da EV. 
- A expressão de filagrina não se altera em ambos os grupos de lesão viral.

- A expressão de e-caderina mantém o padrão habitual intercelular na epiderme, exceto nos focos de coilocitose, onde se apresentou diminuída.

- As alterações observadas são mais acentuadas nas lesões de verruga plana associadas à EV e poderiam se correlacionar com o potencial oncogênico cutâneo da doença. 
ANEXos 


\section{ANEXO 1}

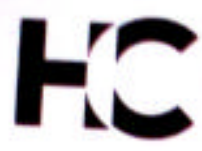

\section{TAS GIINISA}

\section{APROVAÇÃO}

A Comissäo de Ética para Análise de Projetos de Pesquisa - CAPPesq da Diretoria Clinica do Hospital das Clinicas e da Faculdade de Medicina da Universidade de São Paulo, em 24.03.05, APROVOU o Protocolo de Pesquisa $n^{\circ} 101 / 05$, ativa da expressäo de citoqueratinas e e-caderina na verruga plana habitual e na verruga plana da epidermodisplasia verruciforme" apresentado pelo Departamento de DERMATOLOGIA.

Cabe ao pesquisador elaborar e apresentar d CAPPesq, os relatórios parciais e final sobre a pesquisa (Resolução do Conselho Nacional de Saúde $n^{\circ} 196$, de 10.10.1996, inciso IX.2, letra " $c$ ")

Pesquisador(a) Responsável: Dra. Mírian Nacagami Sotto

Pesquisador(a) Executante: Dra.Andrezza Camarinha Napolitano Barcelos

CAPPesq. 24 de Março de 2005

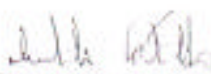

PROF. DR. EUCLIDES AYRES DE CASTILHO

Presidente da Comissão de Ética para Análise de Projetos de Pesquisa

\footnotetext{
Camissbo de Etica pora andise de froje tos de Fetquesa ds har MUSP̈ e de FMUSP

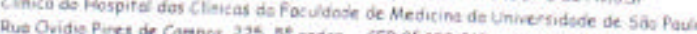

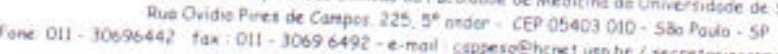




\section{ANEXO 2}

\section{Dados referentes ao sexo, idade, presença de tumores, localização das lesões e expressão de citoqueratinas 1,10,16, 4, e-caderina, involucrina e filagrina nos casos analisados de epidermodisplasia verruciforme e verrugas planas}

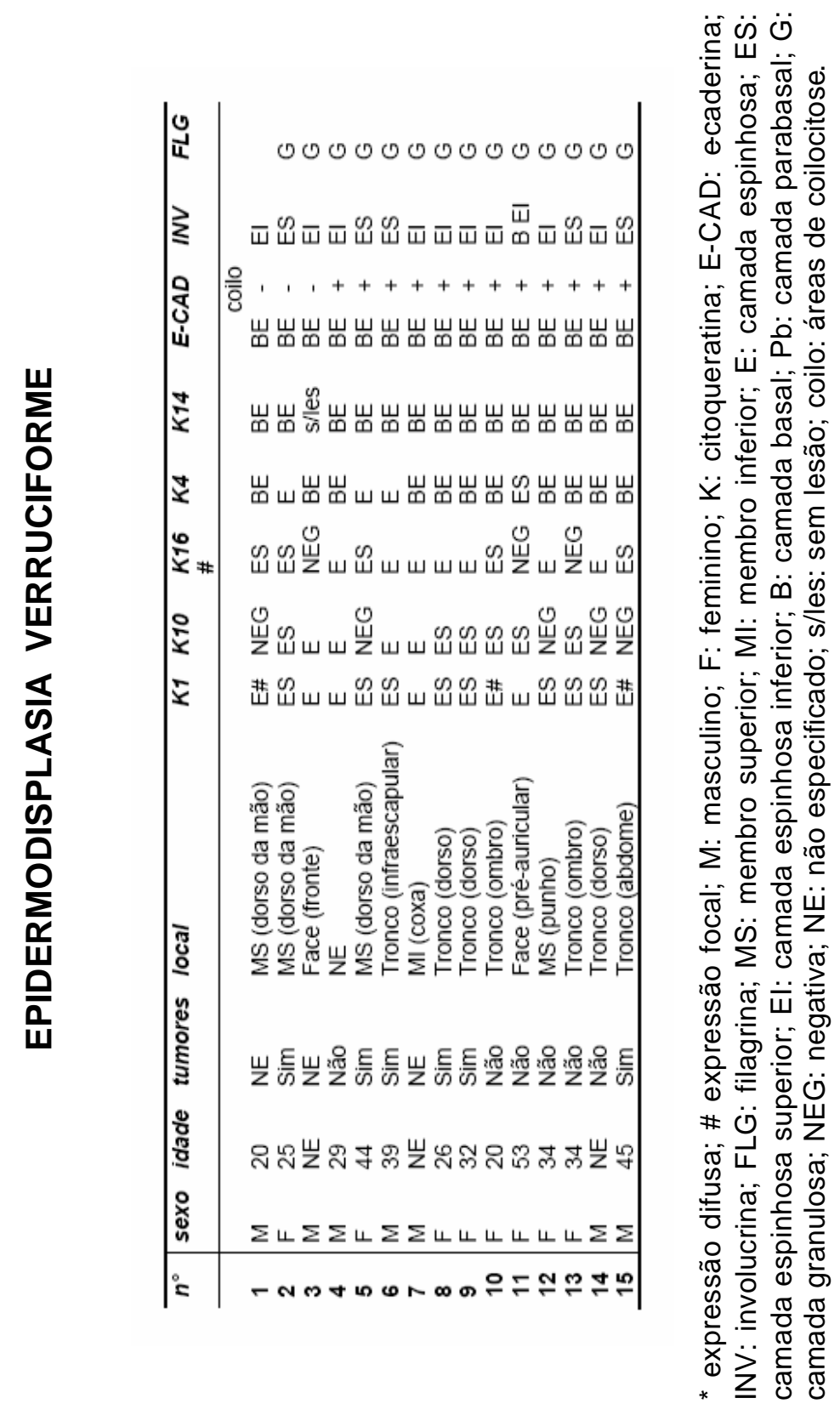




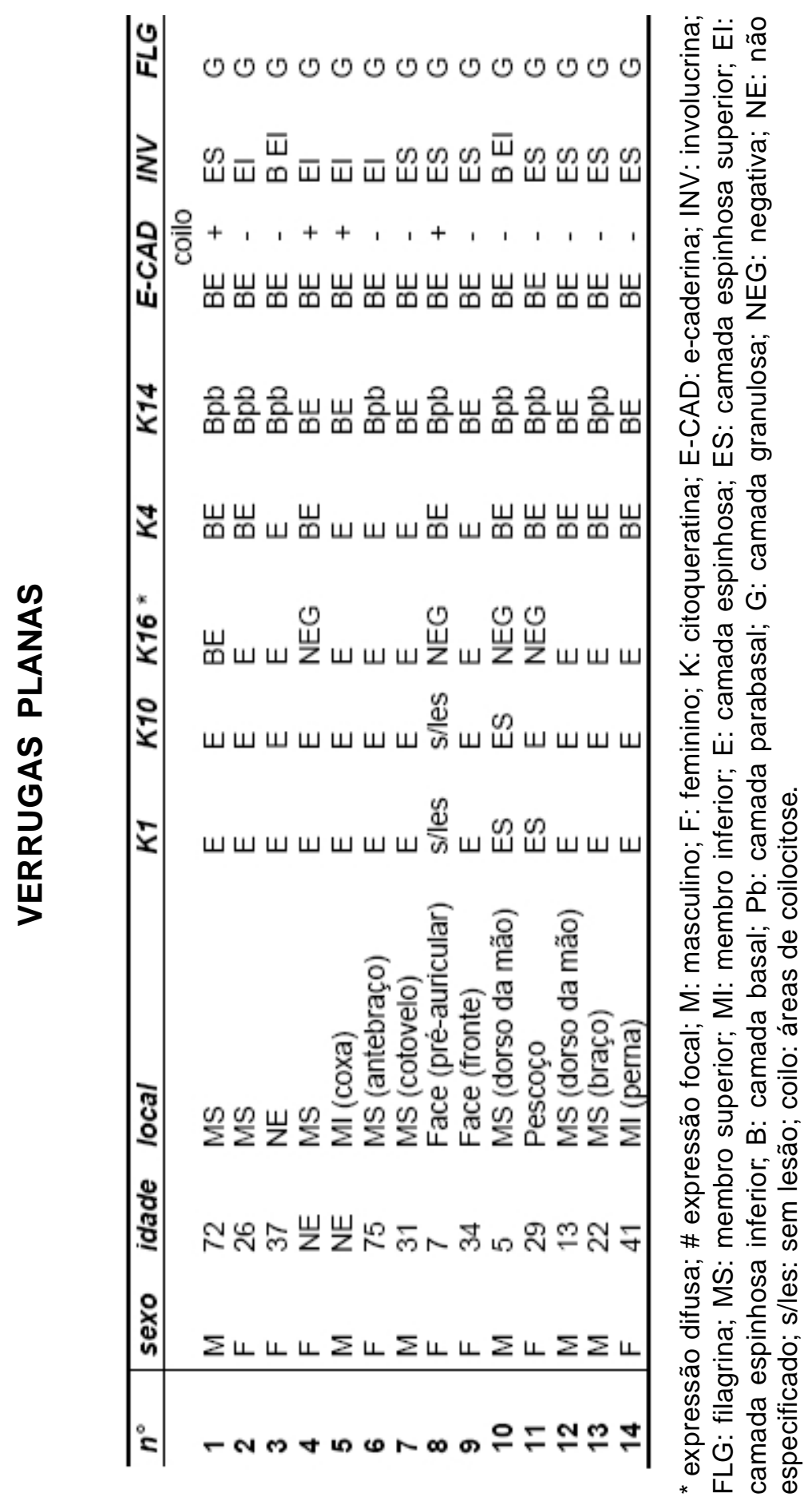




\section{ANEXO 3}

Neoplasias cutâneas com comprovação por exame anatomopatológico de doentes com Epidermodisplasia Verruciforme da casuística

\section{estudada}

\begin{tabular}{|c|c|c|}
\hline CASO & $\begin{array}{l}\text { Tumores } \\
\text { associados }\end{array}$ & LOCALIZAÇÁO \\
\hline 2 & $\begin{array}{l}\text { CEC IN SITU } \\
\text { CEC IN SITU } \\
\text { QA } \\
\text { CEC IN SITU } \\
\text { BOWEN } \\
\text { BOWEN } \\
\text { BOWEN } \\
\text { CEC IN SITU } \\
\text { QA } \\
\text { QA BOWENOIDE } \\
\text { CEC GR2 } \\
\text { CEC SUP/NVASIVO }\end{array}$ & $\begin{array}{l}\text { TORAX } \\
\text { INFRACLAVICULAR } \\
\text { PELE DO COLO } \\
\text { SOE } \\
\text { PANTURRILHA E } \\
\text { BOWEN } \\
\text { SUPRACLAVICULARE } \\
\text { FRONTE } \\
\text { PANTURRILHAE } \\
\text { PRE-ESTERNAL } \\
\text { PRE-ESTERNAL } \\
\text { FRONTE } \\
\text { PALPEBRA INFERIOR }\end{array}$ \\
\hline 5 & $\begin{array}{l}\text { CEC GR3 } \\
\text { CEC } \\
\text { QA } \\
\text { CEC SUP INV } \\
\text { CEC G2 } \\
\text { QA COM FOCO DE } \\
\text { TRANSFORMACAO } \\
\text { QA BOWENOIDE } \\
\text { QA BOWENOIDE } \\
\text { CEC GR4 } \\
\text { CEC SUP INVASIV } \\
\text { CBC } \\
\text { CEC GR1 } \\
\text { QA } \\
\text { QA } \\
\text { QA BOWENOIDE } \\
\text { QA }\end{array}$ & $\begin{array}{l}\text { PALPEBRA SUP } \\
\text { SUPERCILIO D } \\
\text { TEMPORAL D } \\
\text { FRONTE D } \\
\text { FRONTE CENTRAL } \\
\text { PALPEBRA SUP D } \\
\text { FRONTE } \\
\text { PALPEBRA INF D } \\
\text { FRONTE SUP } \\
\text { FRONTE } \\
\text { CANTO OLHO D } \\
\text { FRONTE } \\
\text { CERVICAL } \\
\text { FRONTE } \\
\text { FRONTE MEDIAL } \\
\text { PELE DO LABIO INF }\end{array}$ \\
\hline 6 & $\begin{array}{l}\text { CEC GR2 } \\
\text { CEC GR2 } \\
\text { CBC } \\
\text { CEC SUP INVASIVO } \\
\text { CEC } \\
\text { CBC+VERRUGA VIRAL } \\
\text { CEC IN SITU } \\
\text { CEC }\end{array}$ & $\begin{array}{l}\text { NARIZ } \\
\text { ORELHA } \\
\text { ESTERNAL } \\
\text { TORAX } \\
\text { FÚRCULA } \\
\text { QUIRODÁCTILO } \\
\text { 40 QUIRODACTILO } \\
\text { FRONTE }\end{array}$ \\
\hline
\end{tabular}




\begin{tabular}{|c|c|c|}
\hline CASO & $\begin{array}{l}\text { Tumores } \\
\text { associados }\end{array}$ & LOCALIZAÇÁO \\
\hline 6 & $\begin{array}{l}\text { CEC GR2 } \\
\text { BOWEN } \\
\text { BOWEN }\end{array}$ & $\begin{array}{l}\text { DORSO NASAL } \\
\text { OMOPLATA } \\
\text { DORSO }\end{array}$ \\
\hline 8 & $\begin{array}{l}\text { QA BOWENOIDE } \\
\text { QA } \\
\text { BOWEN } \\
\text { CEC IN SITU }\end{array}$ & $\begin{array}{l}\text { FRONTE } \\
\text { CERVICAL } \\
\text { BRAÇOE } \\
\text { ANTEBRAÇOE }\end{array}$ \\
\hline 9 & $\begin{array}{l}\text { CEC } \\
\text { CBC METASTATICO } \\
\text { CEC GR3 } \\
\text { QA } \\
\text { CEC GR3 } 3 \\
\text { CEC GR3 } 3 \\
\text { CEC GR2 } 2 \\
\text { CEC GR3 } \\
\text { CEC ESCLEROD } \\
\text { CBC MICRONOD } \\
\text { CEC GR3 } \\
\text { QA } \\
\text { CBC } \\
\text { CEC GR3 } \\
\text { CEC GR2 } \\
\text { CBC METATIPICO } \\
\text { CEC GR2 } 2 \\
\text { CEC GR3 } \\
\text { CBC ESCLEROD } \\
\text { CBC ESCLEROD } \\
\text { MELANOACANTOMA } \\
\text { TU DE COLISAO (CEC } \\
\text { E CBC SUPERFICIAL) } \\
\text { QA } \\
\text { BOWEN } \\
\text { CA METATIPICO }\end{array}$ & $\begin{array}{l}\text { NUCA } \\
\text { LINFONODO AXILAR } \\
\text { PRE AURICULAR } \\
\text { PALPEBRA INF } \\
\text { SOE } \\
\text { SOE } \\
\text { ESCAPULAR } \\
\text { TORAX } \\
\text { OMBRO D } \\
\text { PRE AURICULARE } \\
\text { DORSO SUP } \\
\text { INFRAORBITAL } \\
\text { MEDIALD } \\
\text { SUPRACILIAR D } \\
\text { ESCAPULARE } \\
\text { ESCAPULARE } \\
\text { FRONTE } \\
\text { BRAÇO D } \\
\text { ANTEBRACO D } \\
\text { ANTEBRAÇOD } \\
\text { FRONTE } \\
\text { SUPRACLAVICULARE } \\
\text { ANTERBRAÇO D } \\
\text { MALARE } \\
\text { DORSO } \\
\text { FRONTE }\end{array}$ \\
\hline
\end{tabular}




\begin{tabular}{|c|c|c|}
\hline CASO & $\begin{array}{l}\text { Tumores } \\
\text { associados }\end{array}$ & LOCALIZAÇÄO \\
\hline 15 & $\begin{array}{l}\text { CBC } \\
\text { CEC } \\
\text { QA } \\
\text { QA } \\
\text { QUERATOACANTOMA } \\
\text { QUERATOACANTOMA } \\
\text { CBC } \\
\text { CEC GR1 } \\
\text { CEC GR1 } \\
\text { CEC } \\
\text { CBC } \\
\text { CEC IN SITU } \\
\text { CEC GR1 INVASIVO } \\
\text { CBC SUPERFICIAL } \\
\text { CE C GR2 } \\
\text { CEC GR1 } \\
\text { CEC GR1 } \\
\text { QA } \\
\text { CEC GR1 } \\
\text { QA } \\
\text { CEC GR2 } \\
\text { CEC GR2 } \\
\text { CEC } \\
\text { CEC GR2 } \\
\text { CEC GR3 } \\
\text { CEC SUP INVASIVO } \\
\text { CBC SUPERFICIAL }\end{array}$ & $\begin{array}{l}\text { NARIZ } \\
\text { ANTEBRAÇO E } \\
\text { FRONTE } \\
\text { DORSO NASAL } \\
\text { TEMPORAL } \\
\text { FRONTAL } \\
\text { PARANASALE } \\
\text { PARIETALD } \\
\text { PARIETAL E } \\
\text { PANTURRILHA } \\
\text { TRONCO } \\
\text { PUNHO } \\
\text { FACE } \\
\text { FACE ANT TÓRAX } \\
\text { TEMPORALE } \\
\text { FRONTE } \\
\text { C. CABELUDO } \\
\text { C. CABELUDO } \\
\text { C. CABELUDO } \\
\text { C. CABELUDO } \\
\text { FRONTE } \\
\text { FRONTE E } \\
\text { RETROAURICULAR } \\
\text { PARIETOOCCIPITALE E } \\
\text { FRONTOPARIETALE } \\
\text { RETROAURICULAR } \\
\text { SUPRALABIALE }\end{array}$ \\
\hline
\end{tabular}




\section{ANEXO 4}

Comparação da expressão de citoqueratinas 1, 10, 16, 4 e involucrina nas verrugas planas e nas lesões de Epidermodisplasia Verruciforme

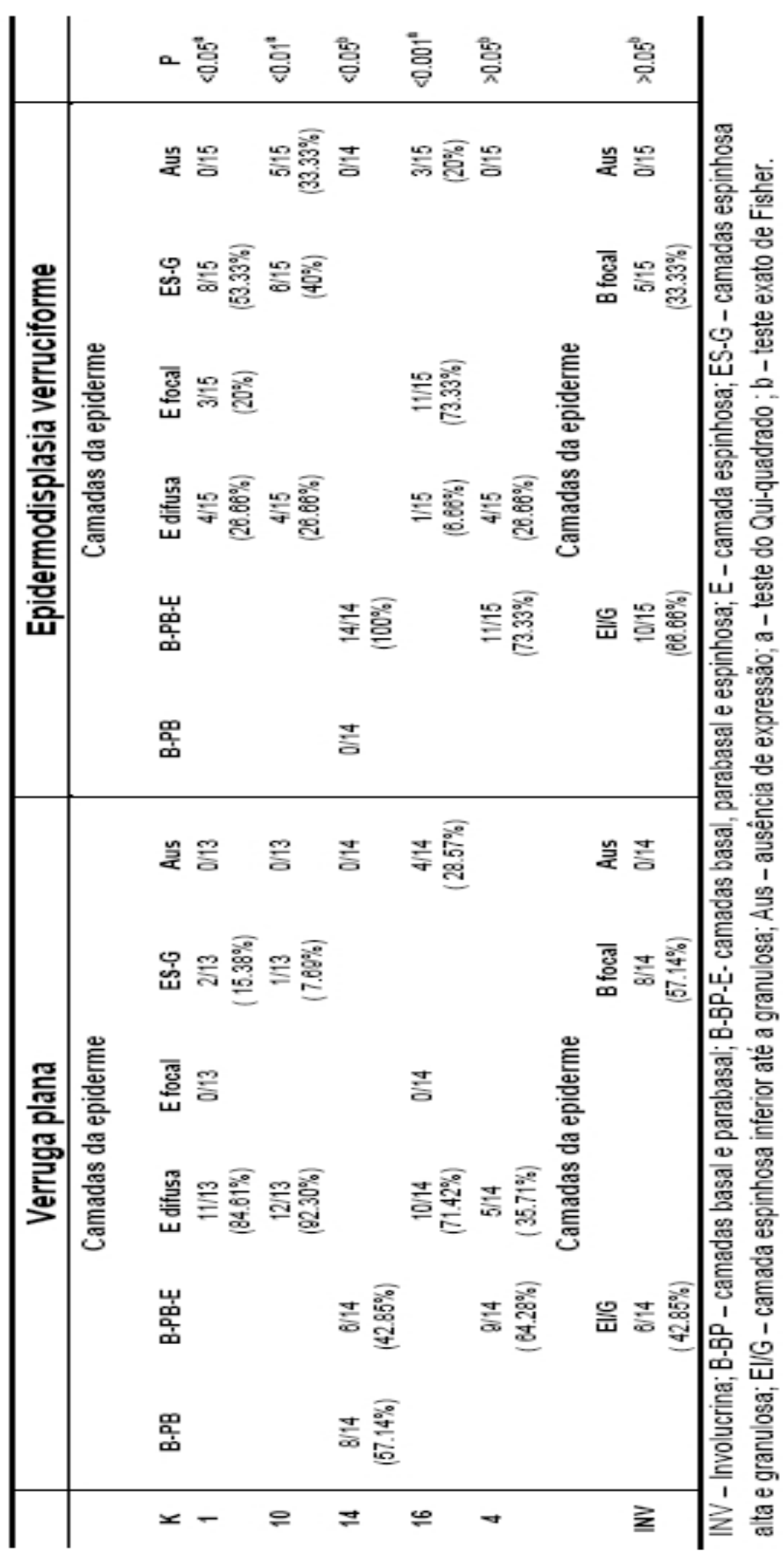




\section{REFERÊNCIAS}




\section{$9 \quad$ Referências}

Akgül B, Karle P, Adam M, Fuchs PG, Pfister HJ. Dual role of tumor suppressor p53 in regeneration of DNA replication and oncogene E6 promoter activity of epidermodysplasia verruciformis - associated human papillomavirus type 8. Virology. 2003;308(2):279-90.

Akgül B, Ghali L, Davies D, Pfister H, Leigh IM, Storey A. HPV8 early genes modulate differentiation and cell cycle of primary human keratinocytes. Exp Dermatol. 2007;16(7):590-9.

Alani RM, Münger K. Human papillomavirus and associated malignancies. $J$ Clin Oncol. 1998;16(1):330-7.

Albers K, Fuchs E. Expression of mutant keratin DNA in epithelial cells reveals possible mechanisms for initiation and assembly of intermediate filaments. J Cell Biol. 1989;108(4):1477-93.

Anadolu R, Oskay T, Erdem C, Boyvat A, Terzi E, Gürgey E. Treatment of epidermodysplasia verruciformis with a combination of acitretin and interferon $\alpha 2 a$. J Am Acad Dermatol. 2001;45(2):296-9.

Androphy EJ, Dvoretzky I, Maluish AE, Wallace HJ, Lowy DR. Response of warts in epidermodysplasia verruciformis to treatment with systemic and intralesional alpha interferon. J Am Acad Dermatol. 1984;11(2Pt1):197-202. 
Androphy EJ, Dvoretzky I, Lowy DR. X-linked inheritance of epidermodysplasia verruciformis. Arch Dermatol. 1985;121(7):864-8.

Androphy EJ. Molecular biology of human papillomavirus infection and oncogenesis. J Invest Dermatol. 1994;103(2):248-56.

Almeida HL Jr, Schaart FM, Pineda S, Orfanos C. Caracterização imunohistoquímica de ceratinócitos humanos epidérmicos e foliculares in vivo e in vitro. An Bras Dermatol. 1994;69(6):467-76.

Almeida HL Jr. Citoqueratinas. An Bras Dermatol. 2004;79(2):135-45.

Alves MT, Roman LC. Estudo do efeito de distintos períodos de fixação em formalina e métodos de recuperação antigênica na técnica imunohistoquímica. J Bras Patol Med Lab. 2005;41(1):43-9.

Antonsson A, Erfurt C, Hazard K, Holmgren V, Simon M, Kataoka A, Hossain S, Håkangård C, Hansson BG. Prevalence and type spectrum of human papillomaviruses in healthy skin samples collected in three continents. J Gen Virol. 2003;84(Pt 7):1881-6.

Aochi S, Nakanishi G, Suzuki N, Setsu N, Suzuki D, Aya K, Iwatsuki K. A novel homozygous mutation of the EVER1/TMC6 gene in a Japanese patient with epidermodysplasia verruciformis. $\mathrm{Br} J$ Dermatol. 2007;157(6):1265-6.

Astori G, Lavergne D, Benton C, Höckmayr B, Egawa K, Garbe C, de Villiers EM. Human papillomaviruses are commonly found in normal skin of immunocompetent hosts. J Invest Dermatol. 1998;110(5):752-5.

Baskan EB, Tunali S, Adim SB, Turan A, Toker S. A case of epidermodysplasia verruciformis associated with squamous cell carcinoma and Bowen's disease: a therapeutic challenge. J Dermatol Treat. 2006;17(3):179-83. 
Bernard BA, Reano A, Darmon YM, Thivolet J. Precocious appearance of involucrin and epidermal transglutaminase during differentiation of psoriatic skin. Br J Dermatol. 1986;114(3):279-83.

Bernerd F, Del Bino S, Asselineau D. Regulation of keratin expression by ultraviolet radiation: differential and specific effects of ultraviolet $B$ and ultraviolet A exposure. J Invest Dermatol. 117(6):1421-9.

Berthelot C, Dickerson MC, Rady P, He Q, Niroomand F, Tyring SK, Pandya AG. Treatment of a patient with epidermodysplasia verruciformis carrying a novel EVER2 mutation with imiquimod. J Am Acad Dermatol. 2007;56(5):882-6.

Bogdan I, Schärer L, Rüdlinger R, Hafner J. Epidermodysplasia verruciformis in two brothers developing aggressive squamous cell carcinoma. Dermatol Surg. 2007;33(12):1525-8.

Boxman IL, Berkhout RJ, Mulder LH, Wolkers MC, Bouwes Bavinck JN, Vermeer BJ, ter Schegget J. Detection of human papillomavirus DNA in plucked hairs from renal transplant recipients and healthy volunteers. $J$ Invest Dermatol. 1997;108(5):712-5.

Boxman IL, Mulder LH, Russell A, Bouwes Bavinck JN, Green A, Ter Schegget J. Human papillomavirus type 5 is commonly present in immunosupressed and immunocompetent individuals. $\mathrm{Br} \mathrm{J}$ Dermatol. 1999;141(2):246-9.

Boxman IL, Mulder LH, Noya F, de Waard V, Gibbs S, Broker TR, ten Kate F, Chow LT, ter Schegget J. Transduction of the E6 and E7 genes of epidermodysplasia-verruciformis-associated human papillomaviruses alters human keratinocyte growth and differentiation in organotypic cultures. $J$ Invest Dermatol. 2001;117(6):1397-404. 
Boxman IL, Russell A, Mulder LH, Bavinck JN, ter Schegget J, Green A; Collaborators of the Nambour Prevention Study. Association between epidermodysplasia verruciformis-associated human papillomavirus DNA in plucked eyebrow hair and solar keratoses. J Invest Dermatol. 2001;117(5):1108-12.

Candi E, Schmidt R, Melino G. The cornified envelope: a model of cell death in the skin. Nat Rev Mol Cell Biol. 2005;6(4):328-40.

Caputo R, Cavicchini S, Brezzi A, Grimalt R. Spiny hyperkeratosis of the fingers as an unusual sign of epidermodysplasia verruciformis. J Acad Dermatol. 1995;32(3):523-4.

Christofori G, Semb H. The role of the cell-adhesion molecule E-cadherin as a tumour-suppressor gene. Trends Biochem Sci. 1999;24(2):73-6.

Cobb MW. Human papillomavirus infection. J Am Acad Dermatol. 1990;22:547-65.

Conacci-Sorrell M, Zhurinsky J, Ben-ze'ev A. The cadherin-catenin adhesion system in signaling and cancer. J Clin Invest. 2002;109(8):987-91.

Cooper KD, Androphy EJ, Lowy D, Katz SI. Antigen presentation and T-cell activation in epidermodysplasia verruciformis. J Invest Dermatol. 1990;94(6):769-76.

Cortés-Franco R, Tyring SK, Vega E, Payne D, Granados J, DomínguezSoto L. Divergent clinical course of epidermodysplasia verruciformis in siblings. Int J Dermatol. 1997;36(6):442-5.

Coulombe PA, Omary MB. 'Hard' and 'soft' principles defining the structure, function and regulation of keratin intermediate filaments. Curr Opin Cell Biol. 2002;14(1):110-22. 
Cribier B, Grosshans E. Les cytokératines dans la peau et le muqueuses malpighiennes. Ann Dermatol Venereol. 1993;120(4):327-35.

Dale BA, Holbrook KA, Kimball JR, Hoff M, Sun TT. Expression of epidermal keratins and filaggrin during human fetal skin development. J Cell Biol. 1985;101(4):1257-69.

de Jong-Tieben LM, Berkhout RJ, Smits HL, Bouwes Bavinck JN, Vermeer BJ, van der Woude FJ, ter Schegget J. High frequency of detection of epidermodysplasia verruciformis-associated human papillomavirus DNA in biopsies from malignant and premalignant skin lesions from renal transplant recipients. J Invest Dermatol. 1995;105(3):367-71.

de Mare S, van Erp PE, Ramaekers FC, van de Kerkhof PC. Flow cytometric quantification of human epidermal cells expressing keratin 16 in vivo after standardized trauma. Arch Dermatol Res. 1990;282(2):126-30.

de Oliveira WR, Festa Neto C, Rady PL, Tyring SK. Clinical aspects of epidermodysplasia verruciformis. J Eur Acad Dermatol Venereol. 2003a;17(4):394-8.

de Oliveira WR, Rady PL, Grady J, Hughes TK, Festa Neto C, Rivitti EA, Tyring SK. Polymorphisms of the interleukin 10 gene promoter in patients from Brazil with epidermodysplasia verruciformis. J Am Acad Dermatol. 2003b;49(4):639-43.

de Oliveira WR, Rady PL, Grady J, Hughes TK, Neto CF, Rivitti EA, Tyring SK. Association of p53 arginine polymorphism with skin cancer. Int $J$ Dermatol. 2004a;43(7):489-93.

de Oliveira WR, Neto CF, Rivitti EA. The lack of a clinical effect of cimetidine in the treatment of epidermodysplasia verruciformis. J Am Acad Dermatol. 2004b;50(6):e14; author reply e15. 
de Oliveira WR, He Q, Rady PL, Hughes TK, Neto CF, Rivitti EA, Tyring SK. HPV typing in Brazilian patients with epidermodysplasia verruciformis: high prevalence of EV-HPV 25. J Cutan Med Surg. 2004c;8(2):110-5.

Doorbar J, Sterling JC. The biology of human papillomavirus. In: Sterling JC, Tyring SK. Human papillomavirus clinical and scientific advances. New York, NY: Oxford University Press; 2001. p.10-23.

Etoh $\mathrm{Y}$, Simon $\mathrm{M}$, Green $\mathrm{H}$. Involucrin acts as a transglutaminase substrate at multiple sites. Biochem Biophys Res Commun. 1986;136(1):51-6.

Evander M, Frazer IH, Payne E, Qi YM, Hengst K, McMillan NA. Identification of the alpha6 integrin as a candidate receptor for papillomaviruses. J Virol. 1997;71(3):2449-56.

Fang F, Zhao I, Jiang MJ, Wang Y, Wang QQ. Epidermodysplasia verruciformis with severe hand and foot deformity successfully treated with surgical excision. J Plast Reconstr Aesthet Surg. 2008;61(3):338-41.

Favre M, Ramoz N, Orth G. Human papillomavirus: general features. Clin Dermatol. 1997;15(2):181-98.

Favre M, Majewski S, De Jesus N, Malejczyk M, Orth G, Jablonska S. A possible vertical transmission of human papillomavirus genotypes associated with epidermodysplasia verruciformis. J Invest Dermatol. 1998a;111(2):333-6.

Favre M, Orth G, Majewski S, Baloul S, Pura A, Jablonska S. Psoriasis: A possible reservoir for human papillomavirus type 5 , the virus associated with skin carcinomas of epidermodysplasia verruciformis. J Invest Dermatol. 1998b;110(4):311-7.

Favre M, Majewski S, Noszczyk B, Maienfisch F, Pura A, Orth G, Jablonska S. Antibodies to human papillomavirus type 5 are generated in epidermal repair processes. J Invest Dermatol. 2000;114(3):403-7. 
Fleckman P, Dale BA, Holbrook KA. Profilaggrin, a high-molecular weight precursor of filaggrin in human epidermis and cultured keratinocytes. $J$ Invest Dermatol. 1985;85(6):507-12.

Forslund O, Lindelöf B, Hradil E, Nordin P, Stenquist B, Kirnbauer R, Slupetzky K, Dillner J. High prevalence of cutaneous human papillomavirus DNA on the top of skin tumors but not in "Stripped" biopsies from the same tumors. J Invest Dermatol. 2004;123(2):388-94.

Fuchs E. Epidermal differentiation: the bare essentials. $J$ Cell Biol. 1990;111(6Pt2):2807-14.

Furukawa F, Fuji K, Horiguchi Y, Matsuyoshi N, Fujita M, Toda K, Imamura $\mathrm{S}$, Wakita H, Shirahama S, Takigawa M. Roles of E- and P-cadherin in the human skin. Microsc Res Tech. 1997;38(4):343-52.

Gewirtzman A, Bartlett B, Tyring S. Epidermodysplasia verruciformis and human papilloma virus. Curr Opin Infect Dis. 2008;21(2):141-6.

Glinski W, Jablonska S, Langner A, Obalek S, Haftek M, Proniewska M. Cell-mediated immunity in epidermodysplasia verruciformis. Dermatologica. 1976;153(4):218-27.

Glinski W, Obalek S, Jablonska S, Orth G. T cell defect in patients with epidermodysplasia verruciformis due to human papillomavirus type 3 and 5 . Dermatologica. 1981;162(3):141-7.

Gober MD, Rady PL, He Q, Tucker SB, Tyring SK, Gaspari AA. Novel homozygous frameshift mutation of EVER1 gene in an epidermodysplasia verruciformis patient. J Invest Dermatol. 2007;127(4):817-20.

Goldman R, Goldman A, Green K, Jones J, Lieska N, Yang HY. Intermediate filaments: possible functions as cytoskeletal connecting links between the nucleus and the cell surface. Ann N Y Acad Sci. 1985;455:167-84. 
Guerin-Reverchon I, Chardonnet Y, Viac J, Chouvet B, Chignol MC, Thivolet J. Human papillomavirus infection and filaggrin expression in paraffinembedded biopsy specimens of extragenital Bowen's disease and genital bowenoid papulosis. J Can Res Clin Oncol. 1990;116(3):295-300.

Guimarães NS, Furtado T, Barbosa AA Jr. Epidermodisplasia verruciforme de Lewandowsky e Lutz. An Bras Dermatol. 1997;72:583-92.

Gül U, Kiliç A, Gönül M, Cakmak SK, Bayis SS. Clinical aspects os epidermodysplasia verruciformis and review of the literature. Int J Dermatol. 2007;46(10):1069-72.

Haftek M, Jablonska S, Orth G. Specific cell-mediated immunity in patients with epidermodysplasia verruciformis and plane warts. Dermatologica. 1985;170(5):213-20.

Haller K, Stubenrauch F, Pfister H. Differentiation dependent transcription of epidermodysplasia verruciformis associated HPV type 5 in benign lesions. Virology. 1995;214(1):245-55.

Harwood CA, McGregor JM, Proby CM, Breuer J. Human papillomavirus and the development of non-melanoma skin cancer. J Clin Pathol. 1999;52(4):249-53.

Harwood CA, Surentheran T, Sasieni P, Proby CM, Bordea C, Leigh IM, Wojnarowska F, Breuer J, McGregor JM. Increased risk of skin cancer associated with the presence of epidermodysplasia verruciformis human papillomavirus types in normal skin. Br J Dermatol. 2004;150 (5):949-57.

Hines MD, Jin HC, Wheelock MJ, Jensen PJ. Inhibition of cadherin function differentially affects markers of terminal differentiation in cultured human keratinocytes. J Cell Science. 1999;112(Pt 24):4569-79.

Hultgren TL, Srinivasan SK, Dimaio DJ. Epidermodysplasia verruciformis occurring in a patient with human immunodeficiency virus: a case report. Cutis. 2007;79(4):307-11. 
Ishida-Yamamoto A, Kartasova $\mathrm{T}$, Matsuo $\mathrm{S}$, Kuroki T, lizuka $\mathrm{H}$. Involucrin and SPRR are synthesized sequentially in differentiating cultured epidermal cells. J Invest Dermatol. 1997;108(1):12-6.

Ivanyi D, Ansink A, Groeneveld E, Hageman PC, Mooi WJ, Heintz AP. New monoclonal antibodies recognizing epidermal differentiation-associated keratins in formalin- fixed, paraffin-embedded tissue: keratin 10 expression in carcinoma of the vulva. J Pathol. 1989;159(1):7-12.

Jablonska S, Fabjanska I, Formas I. On the viral etiology of epidermodysplasia verruciformis. Dermatologica. 1966;132(5):369-85.

Jablonska S, Biczysko W, Jakubowicz K, Dabrowski J. On the viral etiology of epidermodysplasia verruciformis Lewandowsky-Lutz. Electron microscope studies. Dermatologica. 1968;137(2):113-25.

Jablonska S, Dabrowski J, Jakubowicz K. Epidermodysplasia as a model in studies on the role of papovaviruses in oncogenesis. Cancer Res. 1972;32(3):583-9.

Jablonska S, Orth G, Jarzabek-Chorzelska M, Rzesa G, Obalek S, Glinski W, Favre M, Croissant O. Immunological studies in epidermodysplasia verruciformis. Bull Cancer. 1978;65(2):183-90.

Jablonska S, Orth G, Jarzabek-Chorzelska M, Glinski W, Obalek S, Rzesa G, Croissant O, Favre M. Twenty-one years follow-up studies of familial epidermodysplasia verruciformis. Dermatologica. 1979;158(5):309-27.

Jablonska S, Obalek S, Orth G, Haftek M, Jarzabek-Chorzelska M. Regression of the lesions of epidermodysplasia verrruciformis. $\mathrm{Br} J$ Dermatol. 1982;107(1):109-15.

Jablonska S, Obalek S, Wolska $\mathrm{H}$. Follow up of patients with epidermodysplasia verruciformis treated with etretinate. Dermatologica. 1986;173(4):196-9. 
Jablonska S, Majewski S. Epidermodysplasia verruciformis: immunological and clinical aspects. Curr Top Microbio Immunol. 1994;186:157-75.

Jablonska S, Majewski S. Epidermodysplasia verruciformis: what 's new? J Eur Acad Dermatol Venereol. 2003;17(4):381-2.

Jackson S, Harwood C, Thomas M, Banks L, Storey A. Role of Bak in UVinduced apoptosis in skin cancer and abrogation by HPV E6 proteins. Genes Dev. 2000;14(23):3065-73.

Jackson S, Storey A. E6 proteins from diverse cutaneous HPV types inhibit apoptosis in response to UV damage. Oncogene. 2000;19(4):592-8.

Jacyk WJ, Villiers EM. Epidermodysplasia verruciformis in africans. Int $J$ Dermatol. 1993;32:806-10.

Jacyk WK, Dreyer L, de Villiers EM. Seborrheic keratoses of black patients with epidermodysplasia verruciformis contain human papillomavirus DNA. Am J Dermatopatho. 1993;15(1):1-6.

Kallioinen $M$, Koivukangas $V$, Järvinen $M$, Oikarinen $A$. Expression of cytokeratins in regenerating human epidermis. $\mathrm{Br} \quad J$ Dermatol. 1995;133(6):830-5.

Kanda R, Tanigaki T, Kitano Y, Yoshikawa K, Yutsudo M, Hakura A. Types of human papillomaviruses isolated from japanese patients with epidermodysplasia verruciformis. Br J Dermatol. 1989;121(4):463-9.

Kanerva LO, Johansson E, Niemi KM, Lauharanta J, Salo OP. Epidermodysplasia verruciformis. Clinical and light- and electron-microscopic observations during etretinate therapy. Arch Res Dermatol. 1985;278(2):15360 .

Karagas MR, Nelson HH, Sehr P, Waterboer T, Stukel TA, Andrew A, Green AC, Bavinck JN, Perry A, Spencer S, Rees JR, Mott LA, Pawlita M. Human 
papillomavirus infection and incidence of squamous cell and basal cell carcinomas of the skin. J Natl Cancer Inst. 2006;98(6):389-95.

Kariniemi AL, Virtanen I. Altered keratin expression in benign and malignant skin diseases revealed with monoclonal antibodies. Am J Dermatopathol. 1989;11(3):202-8.

Karrer S, Szeimies RM, Abels C, Wlotzke U, Stolz W, Landthaler M. Epidermodysplasia verruciformis treated using topical 5-aminolaevulinic acid photodynamic therapy. Br J Dermatol. 1999;140(5):935-8.

Kawashima M. Epidermodysplasia verruciformis. I Dermatol. 1992;19(11):707-9.

Keresztes G, Mutai $\mathrm{H}$, Heller S. TMC and EVER genes belong to a larger novel family, the TMC gene family encoding transmembrane proteins. BMC Genomics. 2003;17;4(1):24.

Ko CJ, Iftner T, Barr RJ, Binder SW. Changes of epidermodysplasia verruciformis in benign skin lesions: the EV acanthoma. J Cutan Pathol. 2007;34(1):44-8.

Kopan R, Fuchs $\mathrm{E}$. The use of retinoic acid to probe the relation between hyperproliferation-associated keratins and cell proliferation in normal and malignant epidermal cells. J Cell Biol. 1989;109(5):295-307.

Kurokawa I, Mizutani H, Kusumoto K, Nishijima S, Tsujita-Kyutoku M, Shikata N, Tsubura A. Cytokeratin, filaggrin, and p63 expression in reepithelialization during human cutaneous wound healing. Wound Repair Regen. 2006;14:38-45.

Kyriakis K, Pagana G, Michailides C, Emmanuelides S, Palamaras I, Terzoudi S. Lifetime prevalence fluctuations of common and plane viral warts. J Eur Acad Dermatol Venereol. 2007;21(2):260-2. 
Lazarczyk M, Pons C, Mendoza JA, Cassonnet P, Jacob Y, Favre M. Regulation of cellular zinc balance as a potential mechanism of EVERmediated protection against pathogenesis by cutaneous oncogenic human papillomaviruses. J Exp Med. 2008;21;205(1):35-42.

Lazarides E. Intermediate filaments as mechanical integrators of cellular space. Nature. 1980;283(5744):249-56.

Leigh IM, Navsaria H, Purkis PE, McKay IA, Bowden PE, Riddle PN. Keratins ( $\mathrm{K} 16$ and $\mathrm{K} 17$ ) as markers of keratinocyte hyperproliferation in psoriasis in vivo and in vitro. $\mathrm{Br} J$ Dermatol. 1995;133(4):501-11.

Leube RE, Bader BL, Bosch FX, Zimbelmann R, Achtstaetter T, Franke WW. Molecular characterization and expression of the stratification-related cytokeratins 4 and 15. J Cell Biol. 1988;106(4):1249-61.

Lewandowsky F, Lutz W. Ein fall einer bisher nicht beschriebenen Hauterkrankung (Epidermodysplasia verrusiformis). Arch Dermatol Syphilol. 1922;141:193-203.

Li YH, Chen G, Dong XP, Chen HD. Detection of epidermodysplasia verruciformis-associated human papillomavirus DNA in nongenital seborrhoeic keratosis. Br J Dermatol. 2004;151(5):1060-5.

Lourenço SV, Kamibeppu L, Fernandes JD, Sotto MN, Nico MM. Relationship of adhesion molecules expression with epithelial differentiation markers during fetal skin development. J Cutan Pathol. In press 2008.

Lowy DR, Androphy EJ. Warts. In: Freedberg IM, Eisen, AZ, Wolff K, Austen KF, Goldsmith LA, Katz SI. Fitzpatrick's dermatology in general medicine. 5 ed. New York, NY: McGraw-Hill; 1999. v.2, p.2484-97.

Lutzner MA. Epidermodysplasia verruciformis. An autosomal recessive disease characterized by viral warts and skin cancer. A model for viral oncogenesis. Bull Cancer. 1978;65(2):169-82. 
Lutzner MA, Blanchet-Bardon CM, Orth G. Clinical observations, virologic studies, and treatment trials in patients with epidermodysplasia verruciformis, a disease induced by specific human papillomaviruses. $J$ Invest Dermatol. 1984;83(1Suppl):18s-25s.

Lyakhovitsky A, Barzilai A, Fogel M, Trau H, Huszar M. Expression of ecadherin and beta-catenin in cutaneous squamous cell carcinoma and its precursors. Am J Dermatopathol. 2004;26(5):372-8.

Majewski S, Skopinska-Rozewska E, Jablonska S, Wasik M, Misiewicz J, Orth G. Partial defects of cell-mediated immunity in patients with epidermodysplasia verruciformis. J Am Acad Dermatol. 1986;15(5Pt1):96673.

Majewski S, Hunzelmann N, Nischt R, Eckes B, Rudnicka L, Orth G, Krieg T, Jablonska S. TGF $\beta-1$ and TNF $\alpha$ expression in the epidermis of patients with epidermodysplasia verruciformis. J Invest Dermatol. 1991;97(5):862-7.

Majewski S, Jablonska S. Epidermodysplasia verruciformis as a model of human papillomavirus-induced genetic cancers: the role of local immunosurveillance. Am J Med Sci. 1992;304(3):174-9.

Majewski S, Jablonska S. Epidermodysplasia verruciformis as a model of human papillomavirus-induced genetic cancer of the skin. Arch Dermatol. 1995;131(11):1312-8.

Majewski S, Jablonska S, Orth G. Epidermodysplasia verruciformis. Immunological and nonimmunological surveillance mechanisms: role in tumor progression. Clin Dermatol. 1997;15(3):321-34.

Majeswski S, Jablonska S. human papillomavirus - associated tumors of the skin and mucosa. J Am Acad Dermatol. 1997a;36:659-85.

Majewski S, Jablonska S. Skin autografts in epidermodysplasia verruciformis: human papillomavirus-associated cutaneous changes need over 20 years for malignant conversion. Cancer Res. 1997b;57(19):4214-6. 
Majewski S, Jablonska S. Immunology of HPV infection and HPV-associated tumors. Int J Dermatol. 1998;37(2):81-95.

Majewski S, Jablonska S, Favre M, Ramoz N, Orth G. Papillomavirus and autoimmunity in psoriasis. Immunol Today. 1999;20(10):475-6.

Majewski S, Jablonska S. Epidermodysplasia verruciformis. In: Sterling JC, Tyring SK. Human papillomaviruses clinical and scientific advances. New York, NY: Oxford University Press; 2001. p.90-101.

Majewski S, Jablonska S, Favre M, Orth G. Cytokines may favor a role for human papillomaviruses in the pathogenesis of psoriasis. Arch Dermatol. $2001 ; 137(10): 1373$.

Majewski S, Jablonska S. Do epidermodysplasia verruciformis human papillomaviruses contribute to malignant and benign epidermal proliferations? Arch Dermatol. 2002;138(5):649-54.

Majewski S, Jablonska S. Possible involvement of epidermodysplasia verruciformis human papillomaviruses in the immunopathogenesis of psoriasis: a proposed hypothesis. Exp Dermatol. 2003;12(6):721-8.

Majewski S, Jablonska S. Why epidermodysplasia verruciformis - a rare genetic disease - has raised such great interest. Int $J$ Dermatol. 2004;43(4):309-11.

Majewski S, Jablonska S. Current views on the role of human papillomaviruses in cutaneous oncogenesis. Int J Dermatol. 2006;45(3):1926.

Malejczyk J, Majewski S, Jablonska S. Cellular immunity in cutaneous and genital HPV infections. Clin Dermatol. 1997;15(2):261-74.

Matthews K, Leong CM, Baxter L, Inglis E, Yun K, Bäckström BT, Doorbar J, Hibma M. Depletion of Langerhans cells in human papillomavirus type 16- 
infected skin is associated with E6-mediated down regulation of E-cadherin. J Virol. 2003;77(15):8378-85.

McCance DJ, Kopan R, Fuchs E, Laimins LA. Human papillomavirus type 16 alters human epithelial cell differentiation in vitro. Proc Natl Acad Sci USA. 1988;85(19):7169-73.

McGrath JA. Filaggrin and the great epidermal barrier grief. Australas $J$ Dermatol. 2008;49(2):67-73.

McKusik VA, editor. Mendelian inheritance in man. A catalog of human genes and genetic disorders. Baltimore: Johns Hopkins University Press; 1998.

Merrick DT, Blanton RA, Gown AM, McDougall JK. Altered expression of proliferation and differentiation markers in human papillomavirus 16 and 18 immortalized epithelial cells grown in organotypic culture. Am J Pathol. 1992;140 (1):166-77.

Micali G, Nasca MR, Dall'Oglio F, Musumeci ML. Cimetidine therapy for epidermodysplasia verruciformis. J Am Acad Dermatol. 2003;48(2Suppl):S910.

Moll R, Franke WW, Schiller DL, Geiger B, Krepler R. The catalog of human cytokeratins: patterns of expression in normal epithelia, tumors and cultured cells. Cell. 1982;31(1):11-24.

Moll R, Moll I, Franke WW. Differences of expression of cytokeratin polypeptides in various epithelial skin tumors. Arch Dermatol Res. 1984;276(6):349-63.

Moses HL, Yang EY, Pietenpol JA. TGF- $\beta$ stimulation and inhibition of cell proliferation: new mechanistic insights. Cell. 1990;63(2):245-7. 
Motegi S, Tamura A, Endo Y, Kato G, Takahashi A, Negishi I, Ishikawa O. Malignant proliferating trichilemmal tumour associated with human papillomavirus type 21 in epidermodysplasia verruciformis. $\mathrm{Br} J$ Dermatol. 2003;148(1):180-2.

Mullink $H$, Jiwa NM, Walboomers JM, Horstman A, Vos W, Meijer CJ. Demonstration of changes in cytokeratin expression in condylomata accuminata in relation to the presence of human papilloma virus as shown by a combination of immunohistochemistry and in situ hybridization. $A m \mathrm{~J}$ Dermatopathol. 1991;13(6):530-7.

Nagle RB. Intermediate filaments. Efficacy in surgical pathologic diagnosis. Am J Clin Pathol. 1989;91 (4 Suppl 1):S14-8.

Nogueira-Castañon MC, Maya TC, Neves RG. Expression of the cytokeratins in infectious and parasitic skin diseases associated with epidermal hyperplasia. An Bras Dermatol. 2004;79(6):679-87.

Nuovo GJ, Ishag $M$. The histologic spectrum of epidermodysplasia verruciformis. Am J Surg Pathol. 2000;24(10):1400-6.

Okegawa T, Li Y, Pong RC, Hsieh JT. Cell adhesion proteins as tumor suppressors. J Urol. 2002;167(4):1836-43.

Oldak M, Smola H, Aumailley M, Rivero F, Pfister H, Smola-Hess S. The human papillomavirus type 8 E2 protein suppresses $\beta 4$-integrin expression in primary human keratinocytes. J Virol. 2004;78(19):10738-10746.

Oliveira WR. Aspectos clínicos e imunológicos da epidermodisplasia verruciforme. [dissertação] São Paulo: Faculdade de Medicina, Universidade de São Paulo; 1999.

Oliveira WR, Festa C, Tyring SK. Aspectos clínicos da epidermodisplasia verruciforme. An Bras Dermatol. 2002;77:545-56. 
Oliveira WR, Carrasco S, Neto CF, Tyring S. Nonspecific cell-mediated immunity in patients with epidermodysplasia verruciformis. J Dermatol. 2003;30(3):203-9.

Oliveira WR, Rady PL, Festa C, Rivitti EA, Tyring SK. Skin cancer in epidermodysplasia verruciformis patients from brazil. J Eur Acad Dermatol Venereol. 2006;20(9):1154-6.

Orth G, Jablonska S, Favre M, Croissant O, Jarbazek-Chorzelska M, Rzesa G. Characterization of two types of human papillomaviruses in lesions of epidermodysplasia verruciformis. Proc Natl Acad Sci USA. 1978;75(3):153741.

Orth G, Jablonska S, Jarzabek-Chorzelska M, Obalek S, Rzesa G, Favre M, Croissante $\mathrm{O}$. Characteristics of the lesions and risk of malignant conversion associated with the type of human papillomavirus involved in epidermodysplasia verruciformis. Cancer Res. 1979;39(3):1074-82.

Orth G. Genetics of epidermodysplasia verruciformis: Insights into host defense against papillomaviruses. Semin Immunol. 2006;18(6):362-74.

Ostrow RS, Bender M, Niimura M, Seki T, Kawashima M, Pass F, Faras AJ. Human papillomavirus DNA in cutaneous primary and metastasized squamous cell carcinomas from patients with epidermodysplasia verruciformis. Proc Natl Acad Sci USA. 1982;79(5):1634-8.

Padlewska K, Ramoz N, Cassonet P, Riou G, Barrois M, Majewski S, Croissant O, Jablonska S, Orth G. Mutation and abnormal expression of the p53 gene in the viral skin carcinogenesis of epidermodysplasia verruciformis. J Invest Dermatol. 2001;117(4):935-42.

Patel AS, Karagas MR, Pawlita M, Waterboer T, Nelson HH. Cutaneous human papillomavirus infection, the EVER2 gene and incidence of squamous cell carcinoma: a case-control study. Int $J$ Cancer. 2008;122(10):2377-9. 
Pfister $\mathrm{H}$, Ter Schegget J. Role of HPV in cutaneous premalignant and malignant tumors. Clin Dermatol. 1997;15(3):335-47.

Pfister H, Fuchs PG, Majewski S, Jablonska S, Pniewska I, Malejczyk M. High prevalence of epidermodysplasia verruciformis-associated human papillomavirus DNA in actinic keratoses of the immunocompetent population. Arch Dermatol Res. 2003;295(7):273-9.

Pizarro A, Gamallo C, Castresana JS, Gomez L, Palacios J, Benito N, Espada J, Fonseca E, Contreras F. p53 protein expression in viral warts from patients with epidermodysplasia verruciformis. Br J Dermatol. 1995;132 (4):513-9.

Presland RB, Kuechle MK, Lewis SP, Fleckman P, Dale BA. Regulated expression of human filaggrin in keratinocytes results in cytoskeletal disruption, loss of cell-cell adhesion, and cell cycle arrest. Exp Cell Res. 2001;270(2):199-213.

Pyrhönen S, Jablonska S, Obalek S, Kuismanen E. Immune reactions in epidermodysplasia verruciformis. Br J Dermatol. 1980;102(3):247-54.

Rady PL, de Oliveira WR, He Q, Festa C, Rivitti EA, Tucker SB, Tyring SK. Novel homozygous nonsense TMC8 mutation detected in patients with epidermodysplasia verruciformis from a Brazilian family. $\mathrm{Br} J$ Dermatol. 2007;157(4):831-33.

Rajagopalan K, Bahru J, Loo DS, Tay CH, Chin KN, Tan KK. Familial epidermodysplasia verruciformis of Lewandowsky and Lutz. Arch Dermatol. 1972;105(1):73-8.

Rallis E, Papatheodorou G, Bimpakis E, Butanska D, Menounos P, Papadakis $P$. Systemic low-dose isotretinoin maintains remission status in epidermodysplasia verruciformis. J Eur Acad Dermatol Venereol. 2008;22(4):523-5. 
Ramoz N, Rueda LA, Bouadjar B, Favre M, Orth G. A susceptibility locus for epidermodysplasia verruciformis, an abnormal predisposition to infection with the oncogenic human papillomavirus type 5, maps to chromosome 17qter in a region containing a psoriasis locus. J Invest Dermatol. 1999;112(3):259-63.

Ramoz N, Taïeb A, Rueda LA, Montoya LS, Bouadjar B, Favre M, Orth G. Evidence for nonallelic heterogeneity of epidermodysplasia verruciformis with two susceptibility loci mapped to chromosome regions 2 p21 - p24 and 17q25. J Invest Dermatol. 2000;114(6):1148-53.

Ramoz N, Rueda LA, Bouadjar B, Montoya LS, Orth G, Favre M. Mutations in two adjacent novel genes are associated with epidermodysplasia verruciformis. Nat Genet. 2002;32(4):579-81.

Roncalli de Oliveira W, Neto CF, Rady PL, Tyring SK. Seborrheic Keratosislike lesions in patients with epidermodysplasia verruciformis. J Dermatol. 2003;30(1):48-53.

Ruiter M, van Mullem PJ. Demonstration by electronmicroscopy of an intranuclear virus in epidermodysplasia verruciformis. J Invest Dermatol. 1966;47(3):247-52.

Ruiter M, van Mullem PJ. Behavior of virus in malignant degeneration skin lesion in epidermodysplasia verruciformis. $J$ Invest Dermatol. 1970;54(4):324-31.

Sanclemente G, García JJ, Gómez LF, Tyring SK, Wolff JC, Correa LA, Rady $P$. An unusual presentation of human papillomavirus (HPV) infection in a black epidermodysplasia verruciformis (EV) patient. Int $J$ Dermatol. 2007;46(2):199-201.

Sampaio SAP, Rivitti EA. Dermatoses por vírus. In: Sampaio SAP, Rivitti EA. Dermatologia. São Paulo: Artes Médicas; 1998. p.409-30. 
Sehgal VN, Luthra A, Bajaj P. Epidermodysplasia verruciformis: 14 member of a pedigree with an intriguing squamous cell carcinoma transformation. Int J Dermatol. 2002;41(8):500-3.

Silva CS, Ramos RO, Pires MC, Sittart JA. Epidermodisplasia verruciforme: tratamento combinado com aciteretin e interferon alfa-2a. An Bras Dermatol. 2006; 81(6):595-7.

Shamanin V, zur Hausen $H$, Lavergne D, Proby CM, Leigh IM, Neumann C, Hamm H, Goos M, Haustein UF, Jung EG, Plewig G, Wolff H, de Villiers EM. Human papillomavirus infection in nonmelanoma skin cancers from renal transplant recipients an noimmunosupressed patients. J Natl Cancer Inst. 1996; 88(12):802-11.

Smack DP, Korge BP, James WD. Keratin and keratinization. J Am Acad Dermatol. 1994;30(1):85-102.

Smith F. The molecular genetics of keratin disorders. Am J Clin Dermatol. 2003;4(5):347-67.

Smoller BR, Krueger J, McNutt NS, Hsu A. "Activated" keratinocyte phenotype is unifying feature in conditions which predispose to squamous cell carcinoma of the skin. Mod Pathol. 1990;3(2): 171-5.

Staquet MJ, Viac J, Thivolet J. Keratin polypeptide modifications induced by human papillomaviruses (HPV). Arch Dermatol Res. 1981;271(1):83-90.

Stark S, Petridis AK, Ghim SJ, Jenson AB, Bouwes Bavinck JN, Gross G, Stockfleth E, Fuchs PG, Pfister H. Prevalence of antibodies against virus-like particles of Epidermodysplasia verruciformis-associated HPV 8 in patients at risk of skin cancer. J Invest Dermatol. 1998;111(4):696-701.

Schweizer J, Bowden PE, Coulombe PA, Langbein L, Lane EB, Magin TM, Maltais L, Omary MB, Parry DA, Rogers MA, Wright MW. New consensus nomenclature for mammalian keratins. J Cell Biol. 2006;174(2):169-74. 
Steinert PM, Marekov LN.The proteins elafin, filaggrin, keratin intermediate filaments, loricrin, and small proline-rich proteins 1 and 2 are isodipeptide cross-linked components of the human epidermal cornified envelope. J Biol Chem. 1995;270(30):17702-11.

Sterling JC. Human papillomaviruses and skin cancer. $J$ Clin Virol. 2005;32(Suppl 1):S67-71.

Stoler A, Kopan R, Duvic M, Fuchs E. Use of mono-specific antisera and cRNA probes to localize the major changes in keratin expression during normal and abnormal epidermal differentiation. J Cell Biol. 1988;107(2):42746.

Sun XK, Chen JF, Xu AE. A homozygous nonsense mutation in the EVER2 gene leads to epidermodysplasia verruciformis. Clin Exp Dermatol. 2005;30(5):573-4.

Tada $\mathrm{H}$, Hatoko M, Muramatsu T, Shirai T. Expression of e-cadherin in skin carcinomas. J Dermatol. 1996;23(2):104-10.

Tanigaki T, Kanda R. Severe intractable common warts associated with human papillomavirus 2,3 and 20. Dermatologica. 1990;181(2):159-61.

Tate G, Suzuki T, Kishimoto K, Mitsuya T.Novel mutations of EVER1/TMC6 gene in a japanese patient with epidermodysplasia verruciformis. J Hum Genet. 2004;49(4):223-5.

Termorshuizen F, Feltkamp MC, Struijk L, de Gruijl FR, Bavinck JN, van Loveren $\mathrm{H}$. Sunlight exposure and (sero)prevalence of epidermodysplasia verruciformis-associated human papillomavirus. $J$ Invest Dermatol. 2004;122(6):1456-62.

Thewes M, Stadler R, Korge B, Mischke D. Normal psoriatic epidermis expression of hyperproliferation-associated keratins. Arch Dermatol Res. $1991 ; 283(7): 465-71$. 
Thomas P, Said JW, Nash G, Banks-Schlegel S. Profiles of keratin proteins in basal and squamous cell carcinomas of the skin. An immunohistochemical study. Lab Invest. 1984;50(1):36-41.

Tieben LM, Berkhout RJ, Smits HL, Bouwes Bavinck JN, Vermeer BJ, Bruijn JA, Van der Woude FJ, Ter Schegget J. Detection of epidermodysplasia verruciformis-like human papillomavirus types in malignant and premalignant skin lesions of renal transplant recipients. Br J Dermatol. 1994;131(2):22630 .

Tomasini C, Aloi F, Pippione M. Seborrheic keratosis- like lesions in epidermodysplasia verruciformis. J Cutan Pathol. 1993;20(3):237-41.

Tseng SC, Jarvinen MJ, Nelson WG, Huang JW, Woodcock-Mitchell J, Sun TT. Correlation of specific keratins with different types of epithelial differentiation: monoclonal antibody studies. Cell. 1982;30(2):361-72.

Tunggal JA, Helfrich I, Schmitz A, Schwarz H, Günzel D, Fromm M, Kemler $R$, Krieg $T$, Niessen CM. E-cadherin is essential for in vivo epidermal barrier function by regulating tight junction. Embo J. 2005;24(6):1146-56.

Tyner AL, Fuchs E. Evidence for posttranscriptional regulation of the keratins expressed during hyperproliferation and malignant transformation in human epidermis. J Cell Biol. 1986;103(5):1945-55.

Vardy DA, Baadsgaard O, Hansen ER, Lisby S, Vejlsgaard GL. The cellular immune response to human papillomavirus infection. Int J Dermatol. 1990; 29(9):603-10.

Viac J, Guérin-Reverchon I, Chignol MC, Chardonnet Y. Filaggrin expression in cutaneous and mucosal human papillomavirus induced lesions. Pathol Res Pract. 1989;185(3):342-6.

de Villiers EM, Fauquet C, Broker TR, Bernard HU, zur Hausen $H$. Classification of papillomavirus. Virology. 2004;324(1):17-27. 
van Muijen GN, Warnaar SO, Ponec M. Differentiation-related changes of cytokeratin expression in cultured keratinocytes and in fetal, newborn and adult epidermis. Exp Cell Res. 1987;171(2):331-45.

Watanabe S, Ichikawa E, Takahashi H, Otsuka F. Changes of cytokeratin and involucrin expression in squamous cell carcinomas of the skin during progression to malignancy. Br J Dermatol. 1995;132(5):730-9.

Watt FM. Involucrin and others markers of keratinocyte terminal differentiation. J Invest Dermatol. 1983;81(1 Suppl):100s- 3s.

Weedon D. Viral diseases. In: Weedon D. Skin pathology. 2ed London: Churchill Livingstone; 2002. p.703-4.

Weissenborn SJ, Höpfl R, Weber F, Smola H, Pfister HJ, Fuchs PG. High prevalence of a variety of epidermodysplasia verruciformis-associated human papillomaviruses in psoriatic skin of patients treated or not treated with PUVA. J Invest Dermatol. 1999;113(1):122-6.

Wheelock MJ, Jensen PJ. Regulation of keratinocyte intercellular junction organization and epidermal morphogenesis by E-cadherin. J Cell Biol. 1992;117(2):415-25.

Wilding J, Vousden KH, Soutter WP, McCrea PD, Del Buono R, Pignatelli M. E-cadherin transfection down-regulates the epidermal growth factor receptor and reverses the invasive phenotype of human papilloma virus-transfected keratinocytes. Cancer Res. 1996;56(22);5285-92.

Woodworth CD, Waggoner S, Barnes W, Stoler MH, DiPaolo JA. Human cervical and foreskin epithelial cells immortalized by human papillomavirus DNAs exhibit dysplastic differentiation in vivo. Cancer Res. 1990;50(12):3709-15.

Zuo YG, Ma D, Zhang Y, Qiao J, Wang B. Identification of a novel mutation and a genetic polymorphism of EVER1 gene in two families with epidermodysplasia verruciformis. J Dermatol Sci. 2006;44(3):153-9. 